\title{
California air resources board forest carbon protocol invalidates offsets
}

\author{
Bruno D V Marino ${ }^{\text {Corresp., } 1}$, Martina Mincheva ${ }^{2}$, Aaron Doucett $^{3}$ \\ ${ }^{1}$ Executive Management, Planetary Emissions Management Inc., Cambridge, MA, USA \\ 2 Department of Statistics, Temple University, Temple, AZ, United States \\ 3 Planetary Emissions Management Inc., Cambridge, MA, USA \\ Corresponding Author: Bruno D V Marino \\ Email address: bruno.marino@pem-carbon.com
}

The commercial asset value of sequestered forest carbon is based on protocols employed globally, however, their scientific basis has not been validated. We review and analyze commercial forest carbon protocols, claimed to have reduced net greenhouse gas emissions, issued by the California Air Resources Board and validated by the Climate Action Reserve (CARB-CAR). CARB-CAR forest carbon offsets, based on forest mensuration and model simulation, are compared to a global database of directly measured forest carbon sequestration, or net ecosystem exchange (NEE) of forest $\mathrm{CO}_{2}$. NEE is a meteorologically based method integrating $\mathrm{CO}_{2}$ fluxes between the atmosphere, forest and soils and is independent of the CARB-CAR methodology. Annual carbon accounting results for CAR681 are compared with NEE for the Ameriflux site, Howland Forest Maine, USA, (Ho-1), the only site where both methods were applied contemporaneously, invalidating CARB-CAR protocol offsets. We then test the null hypothesis that CARB-CAR project population data fall within global NEE population values for natural and managed forests measured in the field; net annual $\mathrm{gC} \mathrm{m}^{-2} \mathrm{yr}^{-1}$ are compared for both protocols. Irrespective of geography, biome and project type, the CARB-CAR population mean is significantly different from the NEE population mean at the 95\% confidence interval, rejecting the null hypothesis. The CARB-CAR population exhibits standard deviation $\sim 5 x$ that of known interannual NEE ranges, is overcrediting biased, incapable of detecting forest transition to net positive $\mathrm{CO}_{2}$ emissions, and exceeds the 5\% CARB compliance limit for invalidation. Exclusion of $\mathrm{CO}_{2}$ efflux via soil and ecosystem respiration precludes a valid net carbon accounting result for CARB-CAR and related protocols, consistent with our findings. Protocol invalidation risk extends to vendors and policy platforms such as the United Nations Program on Reducing Emissions from Deforestation and Forest Degradation $(\mathrm{REDD}+)$ and the Paris Agreement. We suggest that CARB-CAR and related protocols 
include NEE methodology for commercial forest carbon offsets to standardize methods, ensure in situ molecular specificity, verify claims of carbon emission reduction and harmonize carbon protocols for voluntary and compliance markets worldwide. 
1 Methodology Review

2 California Air Resources Board Forest Carbon Protocol Invalidates Offsets

3 Bruno D.V. Marino ${ }^{1, *}$, Martina Mincheva ${ }^{2}$ and Aaron Doucett ${ }^{3}$

$4 \quad{ }^{1}$ Executive Management, Planetary Emissions Management Inc., Cambridge, MA, USA

$5 \quad{ }^{2}$ Department of Statistics, Temple University, Temple, AZ. USA

6

$7 \quad 3$ Planetary Emissions Management Inc., Cambridge, MA, USA

8

9 Corresponding Author:

10 Bruno D.V. Marino

11 Email address: bruno.marino@pem-carbon.com

12

13

14

15

16

17

18

19

20

21

22

23

24

25

Peer) reviewing PDF | (2019:04:36538:2:0:NEW 31 Jul 2019) 


\section{California Air Resources Board Forest Carbon Protocol Invalidates Offsets}

Bruno D.V. Marino ${ }^{1, *}$, Martina Mincheva ${ }^{2}$ and Aaron Doucett 3

${ }^{1}$ Executive Management, Planetary Emissions Management Inc., Cambridge, MA, USA

2 Department of Statistics, Temple University, Temple, AZ. USA

${ }^{3}$ Planetary Emissions Management Inc., Cambridge, MA, USA

Corresponding Author:

Bruno D.V. Marino

Email address: bruno.marino@pem-carbon.com

\section{Abstract}

The commercial asset value of sequestered forest carbon is based on protocols employed globally, however, their scientific basis has not been validated. We review and analyze commercial forest carbon protocols, claimed to have reduced net greenhouse gas emissions, issued by the California Air Resources Board and validated by the Climate Action Reserve (CARB-CAR). CARB-CAR forest carbon offsets, based on forest mensuration and model simulation, are compared to a global database of directly measured forest carbon sequestration, or net ecosystem exchange (NEE) of forest $\mathrm{CO}_{2}$. NEE is a meteorologically based method integrating $\mathrm{CO}_{2}$ fluxes between the atmosphere, forest and soils and is independent of the CARB-CAR methodology. Annual carbon accounting results for CAR681 are compared with NEE for the Ameriflux site, Howland Forest Maine, USA, (Ho-1), the only site where both methods were applied contemporaneously, invalidating CARB-CAR protocol offsets. We then test the null hypothesis that CARB-CAR project population data fall within global NEE population values for natural and managed forests measured in the field; net annual $\mathrm{gC} \mathrm{m}^{-2} \mathrm{yr}^{-1}$ are compared for both protocols. Irrespective of geography, biome and project type, the CARB-CAR population mean is significantly different from the NEE population mean at the $95 \%$ confidence interval, rejecting the null hypothesis. The CARB-CAR population exhibits standard deviation $\sim 5 x$ that of known interannual NEE ranges, is overcrediting biased, incapable of detecting forest transition to net positive $\mathrm{CO}_{2}$ emissions, and exceeds the 5\% CARB compliance limit for invalidation. Exclusion of $\mathrm{CO}_{2}$ efflux via soil and ecosystem respiration precludes a valid net carbon accounting result for CARB-CAR and related protocols, consistent with our findings. Protocol invalidation risk extends to vendors and policy platforms such as the United Nations Program on Reducing Emissions from Deforestation and Forest Degradation (REDD+) and the Paris Agreement. We suggest that CARB-CAR and related protocols include NEE methodology for commercial forest carbon offsets to standardize methods, ensure in situ molecular 
63 specificity, verify claims of carbon emission reduction and harmonize carbon protocols

64 for voluntary and compliance markets worldwide.

65 Keywords: net forest carbon sequestration, carbon markets, carbon trading, 66 California Air Resources Board, carbon offset uncertainty

67

68

69

70

71

72

73

74

75

76

77

78

79

80

81

82

83

84

85

86

87

88

89

90

91

92

93

94

95

96

97

98

99

\subsection{Introduction}

We review and analyze California Air Resources Board (CARB) protocols representing net annual forest carbon sequestration (Marland et al., 2017) to characterize carbon accounting uncertainty, and ultimately how well the protocol reflects actual net forest carbon sequestration compared to independent and direct measurement of carbon. The CARB protocols must quantify net carbon sequestration as real, additional, permanent, verifiable, and enforceable (California Air Resources Board, 2011, 2014, 2015b), a requirement to ensure that erroneous offsets (e.g., Air Resources Board Offset Credits, or, ARBOC's) do not compromise the integrity of California's AB32, and its successor AB398, mandatory cap on emissions (Nunez, 2016; Schatzki et al., 2018). The CARB issues carbon offsets based on determination of net forest carbon sequestration according to CARB and Climate Action Reserve (CAR) protocols (CARB-CAR); 123 million metric tons of $\mathrm{CO}_{2}$ equivalent $\left(\mathrm{CO}_{2} \mathrm{e}\right)^{\mathrm{i}}$ have been issued since 2006 (California Air Resources Board, 2018a). Forest offsets account for up to $79 \%$ of CARB offsets issued, emphasizing the importance of their validation (California Air Resources Board, 2018a). The CARB-CAR compliance rules stipulate invalidation criteria for offsets that exceed 5\% of actual net forest carbon (e.g., overcrediting) for a period of up to eight years (California Air Resources Board, 2015b, 2015a) and correction of errors due to material misstatement (e.g., percentage error; CARB Air Resources Board, 2013)ij; these criteria have not been widely applied to CARB-CAR offsets. The CARB-CAR protocols and resulting registered offsets have not been independently validated approximately thirteen years since California passed the Global Warming Solutions Act (AB32) in 2006 with the goal of reducing its greenhouse gas (GHG) emissions to 1990 levels by 2020 (Nunez, 2016). Moreover, the lesson learned from false claims of emission reduction by the automotive industry is that all commercial claims of emission reduction must be verified by independent direct measurement (Li et al., 2018) to ensure product value and integrity.

We address the validation gap by comparing CARB-CAR estimated results (e.g., $\mathrm{CO}_{2}$ is not observed directly) with a global database of in situ measured net forest carbon sequestration, or net ecosystem exchange (NEE), (Baldocchi et al., 2018; Baldocchi \& Penuelas, 2019; FLUXNET, n.d.). Three assumptions of the CARB-CAR protocol are evaluated in this review: 1) offsets represent complete forest carbon accounting, 2) results are compliant with CARB-CAR 5\% invalidation rule for overcrediting, and 3 ) 
100

101

102

103

104

105

106

107

108

109

110

111

112

113

114

115

116

117

118

119

120

121

122

123

124

125

126

127

128

129

130

131

132

133

134

135

136

137

results reflect actual net annual forest carbon ecosystem dynamics resulting in verified forest carbon financial products. We present data for selected projects, such as the Howland Forest, Maine, USA, the only location where both methods were applied, and for statistical tests to compare CARB-CAR populations with directly measured forest carbon sequestration population data obtained in the field by the NEE method. The results characterize the uncertainty, accuracy and precision (e.g., interannual variance) of the CARB-CAR protocols, their effect on pricing of forest carbon products and their impacts on carbon market integrity. Protocols related to the CARB-CAR methodology are also assessed for uncertainty and impact on forest carbon markets.

\subsection{Literature survey, Data Sources and Methods}

2.1 CARB-CAR. The CARB-CAR population data used in this study represent 63 sites covering 340 site years, primarily located in the US temperate zone, and have been assigned CAR serial numbers to project offsets (units: $\mathrm{gC}^{-2} \mathrm{yr}^{-}$) (Table 1, Supplements S1,S3-S5 for site information and data). The CARB-CAR projects listed in Table 1 were sourced from the California Air Resources Board and the California Environmental Protection Agency website pages as noted for "Early Action Projects" (CARB, 2015) and as ARBOC's issued (California Air Resources Board, 2018b) as of 09-01-2018, and must adhere to CARB-CAR forest management protocols. Forest project data were accessed through links to a Climate Action Reserve project identification number (CAR\#) providing a project summary page, a document summary page and a cumulative performance report page. The data used in this analysis was sourced directly from the Cumulative Performance Report page and from the column of Verified GHG Reductions for each year of each project or as otherwise reported on the project page when a Cumulative Performance Report was not available (Table I). We reviewed CARB-CAR registry records and history for each project noting discretionary inconsistencies in protocol reporting and process (Table I). The CARB protocols and accounting requirements are described in three related primary documents published in 2011 (California Air Resources Board, 2014), 2014 (California Air Resources Board, 2014) and 2015 (California Air Resources Board, 2015b) entitled: "Compliance Offset Protocol U.S. Forest Projects." The underlying equations for the CARB-CAR protocol are reviewed (Supplement S6) to identify carbon accounting terms and to establish similarities with related protocols including the American Carbon Registry (ACR) (Winrock International, 2016), the Clean Development Mechanism (CDM) (Warnecke, 2014) and the Verified Carbon Standard (VCS) ("Verified Carbon Standard," 2018). The CARBCAR protocols employ limited forest mensuration practice (e.g., forest survey every six years or longer, up to 12 years; California Air Resources Board, 2015b; Marland et al., 2017), vegetation proxies (Cawrse et al., 2009), estimated baselines and growth simulation models (California Air Resources Board, 2011; Climate Action Reserve, 
138

139

140

141

142

143

144

145

146

147

148

149

150

151

152

153

154

155

156

157

158

159

160

161

162

163

164

165

166

167

168

169

170

171

172

173

174

175

$2018 b)$ to determine net forest carbon sequestration. Direct measurement of $\mathrm{CO}_{2}$ in the field does not occur at any point of the protocol process. Additional details are available in the endnotes iii.

2.2 NEE. NEE population data, described by Baldocchi, Chu and Reichstein (2018a), and Baldocchi and Penuelas (2019), herein referred to as NEE1 and NEE2 (units: $\mathrm{gC} \mathrm{m}^{-2} \mathrm{yr}^{-1}$ ), respectively, were employed to assess validity of CARB-CAR results representing direct measurement of $\mathrm{CO}_{2}$ flux. The NEE1 population data represent 59 eddy covariance tower sites, primarily within the US and Canada, with a total of 540 site years. The NEE1 project annual data, employed for the analyses presented, was sourced from each of the NEE1 site references (see Supplements S1, S3-S5 for site information and data) and utilized for comparison with CARB-CAR project interannual data. NEE is also expressed as Net Primary Productivity (NPP) where the term -NEE is employed (Chapin et al., 2006). NEE is a meteorologically based direct measurement method, deployed in the field, integrating all forest $\mathrm{CO}_{2}$ fluxes (e.g., above and below ground) and is methodologically independent of the model and estimation-based CARB-CAR protocol. We provide a graphical interpretation of the NEE1 data in Supplement S7, illustrating the relationship and relative magnitude for NEE (open rectangle, right axis), GPP and $R_{\text {eco }}$ (open circles), filled and gray rectangle symbols represent NEE1 data for the Howland Forest, Maine, USA (Ho-1), and the Wind River (Wrc), Washington, USA, sites, respectively, illustrating overlapping and narrow ranges for diverse forests (e.g., west coast redwoods versus east coast hardwoods). NEE, GPP and $\mathrm{R}_{\text {eco }}$ values falling outside of the known ranges likely do not reflect natural and managed forest ecosystems and are a sign of inaccurate estimates and a basis for invalidation. NEE2 data, inclusive of NEE1 data, expand the GPP, $R_{\text {eco }}$ and NEE population database for ecologically diverse natural and managed forests across 155 global observation platforms representing 1,163 site years. NEE1,2 data are derived from measurement of gaseous molecular $\mathrm{CO}_{2}$ vertical fluxes (Baldocchi et al., 2018; Baldocchi \& Penuelas, 2019) and are based on globally applied and standardized eddy covariance methods (Baldocchi, 2003; Baldocchi, 2014) to quantify NEE (Chapin et al., 2006; Luyssaert et al., 2009) as $\mathrm{tCO}_{2} \mathrm{e}$ or $\mathrm{gC} \mathrm{m}^{-2} \mathrm{yr}^{-1}$. NEE data, available from the Fluxnet database ("Fluxnet," n.d.), are routinely employed to test significance of trends for forest growth (Ney et al., 2019), soil and ecosystem respiration (B. Bond-Lamberty \& Thomson, 2010; Göckede et al., 2019), fire disturbance (Rocha \& Shaver, 2011) and effects of climate change on diverse ecosystems (Yu et al., 2019), similar to the analytical approach employed in this report. Additional information for NEE projects is described in the endnotes ${ }^{\mathrm{iv}}$.

2.3 Statistical Calculations. Individual annual records (units: $\mathrm{gC} \mathrm{m}^{-2} \mathrm{yr}^{-1}$ ) were used in this analysis; trends in time series are not considered. Our analysis is based on population data for NEE, GPP and $R_{\text {eсо }}(\mathrm{NEE1}, 2)$ representing primarily diverse temperate zone

Peer) reviewing PDF | (2019:04:36538:2:0:NEW 31 Jul 2019) 
176 forest ecosystems (Supplement S7) of the world. The tight coupling between GPP and

$177 R_{\text {eco }}$ constrains NEE within relatively narrow boundaries (mean, standard deviation) 178 considering the global spatial and annual time scales reported (Baldocchi \& Penuelas, 179 2019); values falling outside the NEE1,2 boundaries are likely inaccurate, and, with 180 additional criteria may be considered invalid. Although only a single location, the 181 Howland Forest, shares application of both NEE and CARB-CAR protocol, an accurate 182 measurement of net carbon sequestration for any location is expected to comply with the 183 NEE, GPP and $R_{\text {eco }}$ relationship (Supplement S7, filled and gray rectangle symbols for 184 Howland Forest and Washington, GPP and $R_{\text {eco, }}$ respectively). Each data point (whether 185 in NEE or CARB-CAR) comes from the underlying population of the world's forests (e.g., 186 managed or conserved) providing the basis for the two-sample statistical tests presented. 187 We employ standard statistical tests to compare population characteristics, including the 188 accuracy in means and precision (i.e., interannual range) for the CARB-CAR protocol 189 methods, relative to directly measured NEE1,2 population annual values and variance. 190 See Supplement S2 for details of the statistical analyses.

$191 \quad 3.0$ Results

192

3.1 Box Plots. Figure 1 (A) shows the difference in distribution, central values and outliers 193 between the CARB-CAR and NEE1 populations for net forest carbon sequestration. A selected interval of the box plot excluding the CARB-CAR outliers is presented in Figure 1 (B) to illustrate the population differences (CARB-CAR median of $-445.4 \mathrm{gC} \mathrm{m}^{-2} \mathrm{yr}^{-1}$ compared to the NEE1 median value of $-172.5 \mathrm{gC} \mathrm{m}^{-2} \mathrm{yr}^{-1}$ ) corresponding to the larger spread and left-skewness of CARB-CAR values. The population means and standard deviations ( \pm ), for all annual values, Figure 1 (A), of the CARB-CAR and NEE1 datasets are, respectively, $-948.8 \pm 1,504.8 \mathrm{gC} \mathrm{m}^{-2} \mathrm{yr}^{-1}$ and $-198.0 \pm 261.6 \mathrm{gC} \mathrm{m}^{-2} \mathrm{yr}^{-1}$ representing an extreme range of $\sim 5 x$ the value for CARB-CAR forest carbon sequestration mean and $\sim 6 x$

201 standard deviation for interannual variance relative to the NEE1 population data 202 (Baldocchi et al., 2018). The difference in mean values between the two populations is significant at the $95 \%$ confidence level, rejecting the null hypothesis that the CARB-CAR population mean falls within the NEE1 population mean. The mean and standard deviation of the NEE2 data are $-156 \pm 284 \mathrm{gC} \mathrm{m}^{-2} \mathrm{yr}^{-1}$, respectively (155 sites; 1,163 site year), supporting the comparison with CARB-CAR data and $\sim 6 x$ the CARB-CAR mean and $\sim 5 \mathrm{x}$ the standard deviation characterizing interannual ranges for natural and 208 managed forest ecosystems. NEE1,2 natural variation for global forests across management activities is constrained tightly by GPP and $\mathrm{R}_{\text {eco }}$ (Supplement S7) providing boundaries for NEE comparisons. 
213 al., 2018) annual measurements for all years available and for the selected years of 2007

214 and 2008. Given the large difference in sample means for the CARB-CAR and NEE1

215 datasets the true population means may also be significantly different. We test the null

216 hypothesis that the two sample populations were drawn from the same underlying

217 population of annual values for forests. The combined data set consists of 340 CARB-CAR 218 and 540 NEE1 data points ("Total"), each reported as representing an annual cycle 219 determined by each protocol. A formula for a large-sample confidence interval is used for the bar labeled "Total"; no assumption on equal standard deviations between the two data sets has been made. Amongst the years with overlapping data (2001-2014), we choose 2007 and 2008, as they have the largest number of combined sample points, 65 in 2007 (23 for ARB and 42 for NEE1) and 65 in 2008 ( 24 for ARB and 41 for NEE1), excluding initial year values. The null hypothesis that the two data sets come from the same population is rejected implying that CARB-CAR protocols reflect anomalous values and cannot be relied upon to manage forest carbon sequestration. The $5 \%$ estimation error does not overlap with the $95 \%$ confidence interval demonstrating that the CARB-CAR estimates are more than the allowed $5 \%$ from the NEE1 population values. The standard deviation for the CARB-CAR data is very large compared to the NEE1 standard deviation, irrespective of the year. For example, in 2008, the standard deviations for CARB-CAR and NEE1 were respectively, 1,170 and $255 \mathrm{gC} \mathrm{m}^{-2} \mathrm{yr}^{-1}$, a $\sim 5 \mathrm{x}$ over-estimation difference for interannual NEE1 values. This leads to a very wide confidence interval that also establishes that the CARB-CAR project data are invalid based on the permitted $5 \%$ compliance margin of error. To our knowledge, CARB-CAR compliance testing of project results has not been reported employing directly measured forest $\mathrm{CO}_{2}$.

3.3 Project Annual Interval Plot. Figure 3 shows a time interval plot of CARB-CAR annual data from 2002 to 2015 and NEE1 (note: NEE values are illustrated as positive for the purposes of this graph) annual measurements (Baldocchi et al., 2018) from 1992 to 2015 to further test the invalidation of CARB-CAR offsets according to the $5 \%$ invalidation compliance rule. The averages for the two data sets are shown by each vertical bar representing forest carbon sequestration calculated annually over all available locations. The selected intervals are absent first year data for the CARB-CAR population to present a conservative case for testing the null hypothesis. The year 2006 was selected, in which the largest average carbon offset by CARB-CAR sites $(n=12)$ has been recorded, namely $-2,038 \mathrm{gC} \mathrm{m}^{-2} \mathrm{yr}^{-1}$, and apply the corresponding $5 \%$ admissible error of $101.9 \mathrm{gC} \mathrm{m}^{-2} \mathrm{yr}^{-1}$ to all CARB-CAR years, shown as error bars for each CARB-CAR year. No intersection between the admissible interval and the actual NEE1 measurements for any of the overlapping years (2001-2015) is observed. The NEE1 averages through the interval are consistent relative to the large year-to-year fluctuations observed for the CARB-CAR dataset. The null hypothesis is rejected; the CARB-CAR data are invalid by exceeding the $5 \%$ compliance threshold for the years represented in this analysis. The 
252

253

254

255

256

257

258

259

260

261

262

263

264

265

266

267

268

269

270

271

272

273

274

275

276

277

278

279

280

281

282

283

284

285

286

287

288

289

absence of negative values, in this case representing $\mathrm{CO}_{2}$ emissions to the atmosphere, implies that the CARB-CAR protocol is biased against detection of a switch from net sequestration to net positive emissions, arguably a criterion for invalidation.

3.4 p-Values Table. Table II shows the results of a null hypothesis that the difference between the CARB-CAR and the NEE1 annual means is under the allowed 5\% threshold. A year-by-year detailed comparison between the population data sets to further test the $5 \%$ invalidation threshold for the CARB-CAR data is presented. The test is performed separately for all years between 2002 and 2015; p-values are recorded in the last two rows of Table II. The p-values range from 0.00 to 0.065 . Typically, p-values $\leq 5 \%$ demonstrate a rejection of the null hypothesis. The results reject that the estimation error is within the allowed 5\% value, with three exceptions to the 14-year record. In the case of years 2004, 2013 and 2014, the p-values are higher than 5\% (i.e., 6.53\%, 5.48\% and 5.24\%). However, in these cases (i.e., 2004; $p=0.065,2013 ; p=0.055,2014 ; p=0.052$ ) the probability that the CARB-CAR data were not out of the norm is only $1.87 \times 10^{-4} \%$, supporting the null hypothesis rejection. Variation in annual p-values is expected according to the number of data points included per year but represents both populations as overlapping intervals.

3.5 Howland Forest Survey Protocol Comparison. The Howland Research Forest Carbon Project (CAR681) represents the only case in which CARB-CAR and Ameriflux (Ho-1) NEE data are available for the same project location, land area (552 acres; 233.4 hectares), and across shared time intervals (2003 - 2013) allowing direct comparison of results. Comparability of the Ho-1 NEE1 and CAR681 data is established by the location of two eddy covariance towers within the CARB-CAR survey areas. Half-hourly and integrated annual carbon exchange values recorded at the separate Howland towers were similar, with average annual net carbon uptake differing between the two towers by $<6 \%$ (Hollinger et al., 2004, 2013; Richardson et al., 2019) (see Supplement S8 for project area map, sampling locations and CAR681 webpage offset data; Table 1).

CAR681 methodology and calculations described below are reported in the Project Design Document (PDD, published 12-03-2014) (see Table I, link to CAR681 project page). Results for CAR681 include data for the period 2008 to 2013 as hindcasted and reported in 2014; a timber inventory was completed in October 2013. The CAR681 Protocol excludes soil carbon (Table 1, FM-6) (California Air Resources Board, 2015b) (PDD, pp. $10,19)$, employs the common practice method to model onsite above ground carbon stocks of $46 \mathrm{tCO}_{2} \mathrm{e}$ acre $^{-1}\left(18.6 \mathrm{tCO}_{2} \mathrm{e}\right.$ hectare $\left.\mathrm{C}^{-1}\right)$ (PDD, p. 33), and established a timber reinventory interval of 12 years. Model operation (protocol version CARv3.2) included growing the inventory forward 5 years to 2018, then de-growing the inventory to align with the 10/8/2008 start date. Reduced growth rates were selected and employed in model runs to establish the project baseline through a series of estimated growth and harvesting

Peer) reviewing PDF | (2019:04:36538:2:0:NEW 31 Jul 2019) 
290 scenarios over 100 years. CAR681 results are available on the CAR website page: 291 Cumulative Performance Report (Table I, Supplement S8).

292 Carbon sequestration for the initial CAR681 vintage year, 2008, is reported as $-43,687.0$ $293 \mathrm{tCO}_{2} \mathrm{e}$, or $-5,334.7 \mathrm{gC} \mathrm{m}^{-2} \mathrm{yr}^{-1}, \sim 26 \mathrm{x}$ in excess of the reported NEE1 population mean (e.g., $294-198.0 \mathrm{gC} \mathrm{m}^{-2} \mathrm{yr}^{-2}$ ) and $\sim 34 \mathrm{x}$ the NEE2 population mean (e.g., $-156 \mathrm{gC} \mathrm{m}^{-2} \mathrm{yr}^{-2}$ ) 295 (Supplement S7, filled rectangle symbol). Subsequent vintage years, 2009 to 2013, were 296 invariant with exact values of $-1,033.00 \mathrm{tCO}_{2} \mathrm{e}$, or $-126.1 \mathrm{gC} \mathrm{m}^{-2} \mathrm{yr}^{-1}$. CAR681 data for the 297 interval 2008 to 2013 yield a mean and standard deviation of $-994.0 \pm 2,126.1 \mathrm{gC} \mathrm{m}^{-2} \mathrm{yr}^{-1}$, 298 respectively. The total CAR681 offsets issued equal 48,852 $\mathrm{tCO}_{2} \mathrm{e}$ (Table I, Supplement S8, 299 CAR681 Project Page, Cumulative Performance Report). CAR681 results were audited 300 and approved (see link, Table I). Serial numbers were assigned to offsets on 03/13/2015 301 (Table I, Supplement S8).

302 In contrast, Ho-1 NEE for 2008 was reported as $-287.1 \mathrm{gC} \mathrm{m}^{-2} \mathrm{yr}^{-1}$ (Hollinger et al., 2013; 303 Hollinger et al., 2016), 19x smaller compared to the 2008 CAR681 value, representing an 304 over-estimation error of $\sim 1,757 \%$ (e.g., footnote ii). The CAR681 result clearly exceeds the $3055 \%$ CAR invalidation threshold criteria and is arguably invalid. Ho-1 NEE values for the 306 307 308 309 310 years 2009 to 2013 ranged from -191.9 to $-330.9 \mathrm{gC} \mathrm{m}^{-2} \mathrm{yr}^{-1}$ with a mean and standard deviation of $-255.02 \pm 57.7 \mathrm{gC} \mathrm{m}^{-2} \mathrm{yr}^{-1}$, respectively (David Hollinger et al., 2016), reflecting typical interannual ecosystem carbon dynamics. In contrast, the CAR681 model values for 2009 to 2013 were invariant, a trend not observed for NEE1 sites. The CAR681 subsequent year data are in error, on average by $50 \%$ less, compared to the Ho- 1 NEE1 data, an exception for the CARB-CAR population, a trend resulting from selection of model parameters. Ho-1 NEE for the 2008-2013 period totals $\sim 13,446 \mathrm{tCO}_{2} \mathrm{e}$ in contrast to $48,852 \mathrm{tCO}_{2} \mathrm{e}$ based on the CARB-CAR protocol. Ho-1 NEE data for the period 1996 to 2002 and 1996 to 2008 (Hollinger et al., 2004, 2013) have not been compared to CAR681 315 data. CAR681 results $\left(-994.0 \pm 2,126.1 \mathrm{gC} \mathrm{m}^{-2} \mathrm{yr}^{-1}\right)$ do not reflect Ho-1 directly measured mean or interannual values $\left(-255.02 \pm 57.7 \mathrm{gC} \mathrm{m}^{-2} \mathrm{yr}^{-1}\right)$ and cannot be ignored as criteria for invalidation. However, if CARB-CAR data is interpreted as approximating GPP (e.g., not NEE), and $\sim 82 \%$ of assimilated carbon is lost as ecosystem respiration (Hollinger et al., 2013, 2016; NEE1,2), an approximate correction to the CARB-CAR data reduces the mean Howland NEE1 and CARB-CAR population values to $\sim-179$ and $\sim-170 \mathrm{gC} \mathrm{m}^{-2} \mathrm{yr}^{-}$ ${ }^{1}$, respectively, similar to the NEE1 (e.g., $-198 \pm 261.6 \mathrm{gC} \mathrm{m}^{-2} \mathrm{yr}^{-1}$ ) and NEE2 (e.g., $-156 \pm$ $\left.284 \mathrm{gC} \mathrm{m}^{-2} \mathrm{yr}^{-1}\right)$ population means. The high variance for interannual CARB-CAR results (e.g., $\pm 1504.8 \mathrm{gC} \mathrm{m}^{-2} \mathrm{yr}^{-1}$ ) cannot be adjusted based on the correction, nor is the correction proposed as a universal revision to individual CARB-CAR projects. However, the adjustment generally supports the results presented here recognizing that $R_{\text {eco }}$ is absent from CARB-CAR carbon accounting (Supplement S6). This comparison emphasizes the difficulty of determining soil carbon efflux and $R_{\text {eco }}$ terms with CARB-CAR protocol 
328 tools; the NEE method integrates GPP and $R_{\text {eco }}$ fluxes providing NEE (e.g., NEE1,2, 329 Supplement S7).

330 The financial and carbon market consequences for the CAR681 offset errors are

331

332

333

334

335

336

337

338

339

340

341

342

343

344

345

346

347

348

349

350

351

352

353

354

355

356

357

358

359

360

361

362

363

364 substantial. Assuming a 2015 average price of $\$ 9.70$ USD per offset credit $\left(\mathrm{tCO}_{2} \mathrm{e}\right)$ (Hammrick \& Gallant, 2017), sale of CAR681 offsets equal $\sim \$ 473,864$ compared to $\$ 130,431$ for Ho-1 NEE based offsets, a difference of $\$ 343,433$. Overpayment of $\sim 4 x$ for Howland Forest offsets establishes carbon asset value loss and error in subsequent financial transactions including a debit to the AB32 compliance carbon ledger. The initial vintage year overcrediting results from selectively establishing the Common Practice above-ground standing live carbon stock (e.g., $46 \mathrm{tCO}_{2} \mathrm{e} \mathrm{acre}{ }^{-1} ; 31 \mathrm{tC} \mathrm{ha}^{-1}$ ) to $\sim 4 \mathrm{x}$ below the independently determined value for the site (119- $150 \mathrm{tC} \mathrm{ha}^{-1}$; Hollinger et al., 2013). The CARB-CAR estimated baseline scenario maximizes credits generated in the initial year that cannot reflect known rates of $\mathrm{CO}_{2}$ removal from the atmosphere (e.g., 5,332.3 $\mathrm{gC} \mathrm{m}^{-2} \mathrm{yr}^{-1}, \sim 26 \mathrm{x}$ in excess of the reported population annual mean NEE1 data of e.g., $-207.99 \mathrm{gC} \mathrm{m}^{-2} \mathrm{yr}^{-2}$, and 34x the population annual mean NEE2 data of $\left.-156 \mathrm{gC} \mathrm{m}^{-2} \mathrm{yr}^{-2}\right)$. Lowering the Common Practice value relative to actual standing carbon stock for Howland Forest, incorrectly attributes historic carbon (e.g., unknown years of cumulative forest growth prior to the project) to a single vintage initial year of carbon sequestration. In effect, this results in higher initial year crediting, consistent with independent error analyses of similar CARB-CAR projects (Dunlop et al., 2019; Haya, 2019; Haya et al., 2016).

In contrast, Ho-1 NEE increased by $\sim 6 \mathrm{gC} \mathrm{m}^{-2} \mathrm{yr}^{-1}$ over the last 19 years, representing $\sim 50 \%$ overall increase of forest carbon sequestration; each year represents an annual baseline relative to net negative or net positive emissions to the atmosphere (Hollinger et al., 2013; Richardson et al., 2019). There is no initial-year front loading of historic carbon. The time series trend for Ho-1 would not be detected based on the CARB-CAR invariant annual data (excluding first year data), emphasizing the importance of trend detection sensitivity for carbon sequestering ecosystems. Ho-1 provides extensive data to test CARB-CAR protocols including process-based model development (Lee et al., 2018), independent direct measurement of soil $\mathrm{CO}_{2}$ efflux and ecosystem respiration (Giasson et al., 2013), contemporaneous NEE for $\mathrm{CO}_{2}, \mathrm{CH}_{4}$ and $\mathrm{N}_{2} \mathrm{O}$ (Richardson et al., 2019), response to shelterwood harvest (Scott et al., 2004) and diverse ecological data (Giasson et al., 2013). In summary, incomplete carbon accounting, model-based overcrediting carbon offsets by $>5 \%$ relative to actual values, and demonstration that the CARB-CAR results do not agree with actual forest carbon sequestration, invalidate the CARB-CAR protocol for this project. Claimed reductions in net $\mathrm{CO}_{2}$ emissions, carbon offset creation and carbon market transactions cannot be validated with the available data for CAR681 
365 supporting a material misstatement calculation as defined in the AB32 rules (CARB Air 366 Resources Board, 2013) (endnote ii).

367 3.6 CARB-CAR Project Review. Table I summarizes the CARB-CAR project sites $(n=63)$ 368 and attributes considered in this study. Links to serial numbers for specific year vintage 369 offsets issued and to summary pages of the CAR online documentation are provided. 370 Features of the CARB-CAR carbon accounting process are identified and documented: 1) 371 exclusion of the soil carbon pool and soil and ecosystem $\mathrm{CO}_{2}$ emissions as respiration for 372 the 63 CARB-CAR projects (Methods, CARB Protocols) cited in this study, 2) projects that 373 record and assign serial numbers to offsets for single vintage year carbon sequestration 374 but are based on records of partial or multiple years of carbon sequestration (63 375 instances), 3) arbitrary model operations initiated and executed as forward and/or 376 backward runs relative to the project start date (33 instances), and, 4) excess initial year 377 project carbon sequestration values (31 instances). Considerable discretion by CARB378 CAR stakeholders appear to explain protocol inconsistencies; documentation for 379 revisions is not provided. Protocol discretion, including increasing acceptance of default 380 values for protocol components have been documented for related protocols (Kollmuss 381 \& Fussler, 2015) consistent with CAR -CAR protocol observations reported here.

382 3.7 Survey of CARB-CAR Linked Protocols. Similar expressions are employed in the 383 ACR, CDM and VCS protocols (Supplement S6) extending the CARB-CAR carbon 384 accounting uncertainty to large-scale forest carbon projects such as the UN-REDD and 385 REDD+ (United Nations Framework Convention on Climate Change (UNFCCC), n.d.), 386 herein referred to as REDD+. REDD+ approved projects rely on the VCS (supplement S6). 387 Methodologies developed under the United Nations CDM accepts projects and programs 388 registered and approved by the VCS such as method VM0007 REDD+ Methodology 389 Framework (REDD-MF), v1.5 (VERRA, 2015). Technical reports for REDD VCS 390 applications categorically exclude forest soil carbon and ecosystem respiration (e.g., AC391 6) from carbon accounting (UNFCCC, 2017) (Table 1). The implementation of REDD in 392 Ghana, Africa, for example, is subject to impacts of potential invalidation for projects 393 (Asante et al., 2017; Kagombe et al., 2018; McFarland, 2018) including World Bank 394 sponsored bond programs similar to that operating in Kenya, such as the Kasigau 395 Corridor project (McFarland, 2018), also based on VCS protocols. Results for REDD+ 396 programs appear to be uncertain, in part, due to carbon offset monitoring and economics 397 (Foss, 2018). Incomplete carbon accounting implies that results for REDD+ net forest 398 carbon sequestration may not be verifiable or capable of identifying net annual ecosystem 399 carbon change in response to reduced deforestation, climate and anthropogenic forcing, 400 and may not be well suited for carbon pricing and trading of carbon financial 401 instruments. Despite carbon accounting limitations, compliance carbon trading platforms 402 and pricing initiatives are rapidly expanding (e.g., 45 national, 25 subnational 
403 jurisdictions; World Bank and Ecofys., 2018) emphasizing the importance of improved, 404 shared methodology for forest carbon sequestration product offerings. Although it is not 405 clear how REDD+ will be integrated within the Paris Agreement (e.g., Article 6) 406 (Schneider \& La Hoz Theuer, 2018) or into existing compliance markets (Hein et al., 2018), 407 improved quantification of forest carbon sequestration would link REDD+ entities and 408 mechanisms together in a harmonized universal science-based transactional framework. Macroeconomic trends consistent with offset invalidation risk for voluntary and carbon trading markets are provided in endnotev ${ }^{\mathrm{v}}$.

411

412

413

414

415

416

417

418

419

420

421

422

423

424

425

426

427

428

429

430

431

432

433

434

435

436

437

438

439

440

3.8 CARB-CAR CA Site Data. The CARB-CAR project sites within California, representing 31 of the 63 projects (Table I), represent a mean and standard deviation of $-1163.2 \pm 1,889.8$, respectively, more negative and variable than values for the CARB-CAR population data set ( 63 projects) of $-948.8 \pm 1,504.8 \mathrm{gC} \mathrm{m}^{-2} \mathrm{yr}^{-1}$. The CA sites establish the anomalous nature for this group relative to NEE1 $\left(-198.0 \pm 261.6 \mathrm{gC} \mathrm{m}^{-2} \mathrm{yr}^{-1}\right)$ (Supplement S7) and NEE2 $\left(-156.0 \pm 284.0 \mathrm{gC} \mathrm{m}^{-2} \mathrm{yr}^{-1}\right)$ with up to $\sim 7 \mathrm{x}$ the mean and $\sim 12 \mathrm{x}$ the standard deviation (e.g., interannual variance) relative to NEE2 population values. The CARBCAR sites are located generally within the western mountain biome and the marine coastal zones. The CARB-CAR biomes extend from southern to northern California to Oregon and Washington (Supplements S1, S7, filled gray rectangle symbol), with similar ecological patterns to support characteristic forest species. The CA CARB-CAR sites report invariant values (i.e., interannual variance of 0.0) for CAR590 (5 of 5 years), CAR694 (5 of 7 years), and CAR935 (12 of 14 years), that do not reflect natural forest ecosystems. Direct overlap of CARB-CAR and NEE methods is not required to establish the anomalous features of forest growth implied by the results for CA CARB-CAR sites relative to known population values. An accurate measurement of net carbon sequestration for any forest location is expected to comply with the GPP vs $R_{\text {eco }}$ relationship for NEE1 (Supplement S7, filled black and gray rectangle symbols for west and east coast forest values as described) and NEE2 (e.g., $-156.0 \pm 284.0 \mathrm{gC} \mathrm{m}^{-2} \mathrm{yr}^{-1}$ ). The CA CARB-CAR project sites according to the statistical analysis of NEE1 sites (e.g., Figs. 1-3, Table II) and comparison with NEE1,2 data, indicate that the CA CARB-CAR sites do not represent realistic forest carbon sequestration and are arguably invalid.

\subsection{Discussion}

The offset errors, discretionary protocol inconsistencies, incomplete carbon accounting and statistical differences between the Howland Forest (CAR681) project data and directly measured contemporaneous Ho-1 NEE data pose an insuperable factual challenge to the scientific, regulatory and financial validity of the CARB-CAR protocol process and CARB compliance offsets. The consequences of erroneous financial transactions (i.e., $\sim 4 \mathrm{x}$ overpayment), overcrediting to compliance carbon markets, early project termination, and loss of opportunity to manage net removal of atmospheric $\mathrm{CO}_{2}$ 
441 do not satisfy the stated AB32 policy goals to "quantify net carbon sequestration as real, 442 additional, permanent, verifiable, and enforceable" (California Air Resources Board, 443 2011, 2014, 2015b; Nunez, 2016). Net GHG removal, while stated as the objective of the 444 CARB-CAR protocol, falls short of including established carbon accounting protocol 445 terms for soil and ecosystem carbon efflux to achieve the required result (e.g., RF-6, IFM446 6, AC-6, Methods 2.1, Table I). The CAR681 project offsets exceed the allowable 5\% 447 threshold for overcrediting error (i.e., section 95985 of the AB32 regulation) rending 448 buffer pools of limited value in compliance enforcement. The CAR681 data (i.e., 449 anomalous initial year value, invariant subsequent years) has no counterpart in nature 450 and is arguably invalid on this basis. The CARB-CAR Howland Forest project did not 451 452

453

454

455

456

457

458

459

460

461

462

463

464

465

466

467

468

469

470

471

472

473

474

475

476

477

478

479 result in a long-term comparison between the protocols; 2014 was the last vintage year reported. In contrast, NEE data collection for Howland Forest has continued, comprising one of the longest NEE time series on record (1996-present) ("US-Ho1: Howland Forest (main tower)," n.d.) documenting interannual changes in forest carbon storage balance between GPP and $R_{\text {eco }}$ (Baldocchi \& Penuelas, 2019). The well-established anomalous nature of CA CARB-CAR projects $(-1,163.2 \pm 1880, n=31)$, do not require site-specific overlapping NEE data for comparison with NEE1,2 population data to conclude that the CA site data do not reflect known ranges for NEE and are arguably invalid, consistent with systemic errors noted for Howland Forest (e.g., 31 cases of anomalous initial year values, Table I). Cases for invalidation based on problems of additionality and leakage (Dunlop et al., 2019; Haya, 2019) as well as questions raised by extension of CARB-CAR protocols to REDD+ tropical forests (Results 3.7, endnote vi) (California Air Resources Board, 2018c), underscore the need and importance of resolving CARB-CAR protocol uncertainties.

Exclusion of the soil carbon and ecosystem respiration fluxes impose additional invalidation uncertainty for CARB-CAR protocols by the requirement of a 100-year invariant project baseline to ensure forest carbon storage permanence (California Air Resources Board, 2011, 2014, 2015b; Climate Action Reserve, 2018b). Soil carbon comprises up to three times the magnitude of above ground carbon composition, contributes up to $\sim 82 \%$ of ecosystem carbon exchange (Baldocchi \& Penuelas, 2019; Barba et al., 2018; Giasson et al., 2013; Hollinger et al., 2013) and cannot be excluded from a complete, scientifically valid, carbon sequestration value for a forest project (Comeau et al., 2018; DiRocco et al., 2014; $\mathrm{Li}$ et al., 2018). Soil warming and related soil $\mathrm{CO}_{2}$ efflux predictions, including feedbacks to the biosphere (Davidson \& Janssens, 2006), vary over the coming decades (Ben Bond-Lamberty et al., 2018; Hicks Pries et al., 2017; Melillo et al., 2011; Wang et al., 2014; Yang et al., 2013) but they typically deny the assumption that the soil carbon pool and resulting fluxes will remain invariant over the 100-year required project interval (Ben Bond-Lamberty et al., 2018; W. Li et al., 2018). The global soil-toatmosphere (e.g., total soil respiration) $\mathrm{CO}_{2}$ flux, driven by climate change, is increasing 
480

481

482

483

484

485

486

487

488

489

490

491

492

493

494

495

496

497

498

499

500

501

502

503

504

505

506

507

508

509

510

511

512

513

514

515

516

across diverse contemporaneous ecosystems (Ben Bond-Lamberty et al., 2018), a trend supported by a series of NEE observation platforms, inclusive of 19 of the 59 NEE1 sites represented in this study (Baldocchi, 2008; Baldocchi et al., 2018; B. Bond-Lamberty \& Thomson, 2010). The CARB-CAR estimated invariant baselines, and the invariant interannual records (Table 1 ) have no counterpart in nature and should be replaced by direct measurement. The omission of soil-based $\mathrm{CO}_{2}$ efflux for CARB-CAR and related protocols preclude differentiation of net-negative to net-positive $\mathrm{CO}_{2}$ forest emissions, a critical test for forest carbon protocols, and a criterion for invalidation.

The CARB-CAR and NEE1 comparison establish systemic uncertainty and corrective action that apply broadly to the CARB-CAR and linked protocols (e.g., ACR, CDM, VCS) (Supplement S6), including: 1) absence of direct, high frequency molecular $\mathrm{CO}_{2}$ measurement to determine annual NEE, a requirement for project validation compliance testing and enforcement, corrected by inclusion of $\mathrm{CO}_{2}$ flux measurements, 2) incomplete carbon accounting by exclusion of GPP and $\mathrm{R}_{\mathrm{eco}}$, corrected by requiring inclusion of soil carbon and ecosystem respiration terms, 3) discretionary adjustment of model growth forecasts (e.g., selection of FVS values) to achieve specific project goals including baseline levels, corrected by regulation of protocol rules, 4) creation of excess initial-year project vintage carbon sequestration values exceeding the known range of NEE values, violating the $5 \%$ invalidation threshold, corrected by using actual NEE measurement for year one in the same manner as for all years, and, 5) creation of unverified forest carbon financial products for carbon market transactions, corrected by employing third party verifiers with independent $\mathrm{CO}_{2}$ measurements.

The protocol inconsistencies and invalidation criteria noted above (e.g., Howland Forest) support results of statistical analyses for CARB-CAR and NEE1 population comparisons. Mean values, Fig. 1 (A,B), and discrete interannual segments including exclusion of initial year data (e.g., Fig. 2,3, low p-values Table II) were compared with the same result: the CARB-CAR protocol cannot be relied upon to represent valid net annual forest carbon dynamics and will likely exceed the $5 \%$ compliance threshold. Results for CARB-CAR net carbon sequestration cannot be argued as exceptions to known variance for forest populations (i.e., mean and standard deviation), but rather stand clearly outside of the known boundaries (Supplement S7). We argue that the diverse analyses reported, considered together, provide robust observational evidence that the CARB-CAR and related protocols do not reliably reflect known values for forest carbon sequestration and are invalid.

The problems with estimation-based protocols can be addressed with existing technology and scientific methods. In contrast to estimation-based protocols, NEE for $\mathrm{CO}_{2}$ determined by eddy covariance integrates vertical carbon fluxes between forest and soil 
517 ecosystems and atmosphere (e.g., assimilation and respiration) (Burba, 2013), resulting in 518 the key outcome of net forest carbon sequestration (e.g., NEE as gC $\mathrm{m}^{-2} \mathrm{yr}^{-1}$ ). The eddy 519 covariance method employed at the Howland Forest and NEE1,2 sites has been applied 520 worldwide as standalone field research installations (Burba, 2013; Curtis \& Gough, 2018; 521 Eddy Covariance, 2012; Lee, 2017) in combination with remote sensing (Hopkinson et al., 522 2016; Liu et al., 2016) and as research networks (FLUXNET, n.d.; Novick et al., 2018; 523 Ocheltree et al., 2007; Papale \& Valentini, 2003) for $\mathrm{CO}_{2}, \mathrm{CH}_{4}$ and $\mathrm{N}_{2} \mathrm{O}$, capability that 524 cannot be implemented by CARB-CAR and related protocols. Eddy covariance networks 525 are not typically interconnected in real-time or applied across large project areas for 526 creating commercial forest carbon financial products. Commercial engineering 527 development of low-cost eddy covariance networks, to attain state-wide spatial coverage

528

529

530

531

532

533

534

535

536

537

538

539

540

541

542

543

544

545

546

547

548

549

550

551

552

553 across the US or for specific regions, for example, coupled with innovative features, including unmanned aerial vehicles (Berman et al., 2012; Metzger et al., 2012), shared data networks (Dai et al., 2018) and automated reporting is achievable offering a modernized alternative to estimation protocols. Advancements in blockchain accounting platforms (Düdder \& Ross, 2017), artificial intelligence (Reis et al., 2018) and the internet of things (Subashini et al., 2018) can be readily integrated within eddy covariance networks but for the reasons we discuss here cannot be successful without direct measurement of $\mathrm{CO}_{2}$. Eddy covariance as an instrumental method has characteristic limitations and uncertainties (Nicolini et al., 2018) and faces engineering challenges for large-scale deployment as well as upscaling eddy covariance methods (Barba et al., 2018; Kumar et al., 2016; Ran et al., 2016; Warner et al., 2019; Wutzler et al., 2018). NEE platforms and networks are established in numerous countries including those with REDD+ platforms and commitments to the Paris Agreement providing a foundation for expanded NEE observations to support global climate change policies.

Given the feasibility of establishing eddy covariance networks, expanding carbon market exchanges (World Bank and Ecofys., 2018) and the abundance of deforested landscapes, we suggest that standard methods and protocols be adopted for forest carbon and GHG financial products that: 1 ) are based on direct measurement of molecular $\mathrm{CO}_{2}$ forest flux, 2) employ shared gas standards for $\mathrm{CO}_{2}$ analyzer calibration, performance testing (e.g., World Meteorological Organization; Brailsford, 2012) and global reference frameworks (Andrews et al., 2019), 3) employ standardized protocols, model parametrizations and criteria such as that established by the Integrated Carbon Observation System (Kutsch et al., 2018; Vitale \& Papale, 2017; Wutzler et al., 2018) (ICOS) and the Global Atmosphere Watch (Schultz et al., 2015), and, 4) establish universal measurement-based criteria for the transformation of NEE to forest carbon offset products suitable for carbon financial transactions. 
554 We acknowledge the limitations of this study related to the small sample sizes for annual 555 intervals presented and limited overlapping project sites. However, in the absence of 556 CARB-CAR validation and apparent protocol discrepancies reported here, NEE offers the 557 best available data for independent verification. The results presented here form the basis 558 for ongoing comparison between CARB-CAR and NEE1,2 results. CARB-CAR CA sites, 559 likely to increase based on AB398 legislation (Schatzki et al., 2018), we suggest, should 560 incorporate current and evolving NEE methods, terminology and knowledge of forest 561 carbon sequestration in collaboration with NEE research efforts.

562

563

564

565

566

567

568

569

570

571

572

573

574

575

576

577

578

579

580

581

582

583

584

585

586

587

588

589

590

591

\subsection{Conclusions}

In conclusion, our results, unless proven otherwise, call into question the scientific, regulatory and financial validity of estimation-based protocols for net forest carbon. Diverse criteria demonstrate that CARB-CAR protocols are unreliable and unlikely to represent actual carbon sequestration and are invalid. The importance and urgency of validating forest carbon sequestration cannot be overestimated as forests provide additional ecosystem services of soil carbon sequestration and water conservation (Masciandaro et al., 2018), biodiversity safeguards (Keesstra et al., 2018), and the coupling of avoided forest carbon emissions with Indigenous Peoples habitation (Mesoamerican Alliance of Peoples and Forests (MAPF), 2015; Ramos-Castillo et al., 2017). Measurement and standardized methods are hallmarks of the Montreal Protocol to monitor and enforce the reduction in emission of chlorofluorocarbons demonstrating the success of collective action within a common standardized analytical framework (Bielewski \& Śliwka, 2014; Hurst et al., 1998; Newman, 2018). Nothing less is required to advance forest carbon management and carbon market value. The demise of the Chicago Climate Exchange (Sabbaghi \& Sabbaghi, 2017), coincident with near zero-dollar value for forest carbon (Peters-Stanley et al., 2012), and false claims of automotive emission avoidance offers a lesson learned that without actual measurement and accountability, institutional GHG emission reduction frameworks are vulnerable to economic and policy failure (Van Renssen, 2018) and fraud ( $\mathrm{Li}$ et al., 2018). Project specific climate finance and monetization mechanisms are a key but unspecified component of the Paris Agreement that if combined with direct measurement of forest $\mathrm{CO}_{2}$ will benefit societies and economies in the coming decades and prove crucial to correcting the imbalance between nature and anthropogenic activity and resulting climate change.

Acknowledgements. The references cited in this study referring to eddy covariance data were acquired and shared by the FLUXNET community, including potentially these networks: AmeriFlux, AfriFlux, AsiaFlux, CarboAfrica, CarboEurope-IP, CarboItaly, CarboMont, ChinaFlux, FLUXNET Canada, Green- Grass, ICOS, KoFlux, LBA, NECC, TERN OzFlux, TCOS-Siberia, and USCCC. Detailed data (e.g., annual records) cannot be shared publicly because of Fluxnet2015 (https:// fluxnet.fluxdata.org/data/data- 
592 policy/) and Lathuile (https://fluxnet.fluxdata.org/data/la-thuile-dataset/) data policies.

593 Annual values used in this study were acquired from individual references cited in

594 NEE1Baldocchi et al., 2018).

595 Data Availability. All data is provided in Supplementary Information.

596 Author Contributions: B.D.V.M. conceived the research, developed and wrote the 597 manuscript; M.M. performed the statistical analysis; A.D. constructed the interactive 598 map.

599 Funding: This research received no external funding.

600 Conflicts of Interest: The authors declare no conflict of interest.

\section{References}

602

603

604

605

606

607

608

609

610

611

612

613

614

615

616

617

618

619

620

621

622

623

American Carbon Registry. (2018). Retrieved from https://acr2.apx.com/myModule/rpt/myrpt.asp

Andrews, E., Sheridan, P. J., Ogren, J. A., Hageman, D., Jefferson, A., Wendell, J., Alástuey, A., Alados-Arboledas, L., Bergin, M., Ealo, M., Gannet Hallar, A., Hoffer, A., Kalapov, I., Keywood, M., Kim, J., Kim, S. W., Kolonjari, F., ... Sun, J. (2019).

Overview of the NOAA/ESRL federated aerosol network. Bulletin of the American Meteorological Society, 100(1), 123-135. https://doi.org/10.1175/BAMS-D-17-0175.1

Asante, W., Lawrence, E., Dawoe, K., \& Bosu, P. P. (2017). A new perspective on forest definition and shage regines for REDDD+ interventions in Ghana's cocoa lanscape: Assessing and Enhancing the Resilience of the Tef and Cocoa Value Chains in Ethiopia and Ghana (AERTCvc). Ghana J. Forestry, 33, 1-15. https://doi.org/10.13140/RG.2.2.14758.42564

Baldocchi, D. (2003). Assessing the eddy covariance technique for evaluating carbon dioxide exchange rates of ecosystems: Past, present and future. Global Change Biology, 9(4), 479-492. https://doi.org/10.1046/j.1365-2486.2003.00629.x

Baldocchi, D. (2008, February 28). Turner Review No. 15. "Breathing" of the terrestrial biosphere: Lessons learned from a global network of carbon dioxide flux measurement systems. Australian Journal of Botany. CSIRO PUBLISHING. https://doi.org/10.1071/BT07151

Baldocchi, D. (2014). Measuring fluxes of trace gases and energy between ecosystems and the atmosphere - the state and future of the eddy covariance method. Global Change Biology, 20(12), 3600-3609. https://doi.org/10.1111/gcb.12649 
624 Baldocchi, D., \& Penuelas, J. (2019). The physics and ecology of mining carbon dioxide 625 from the atmosphere by ecosystems. Global Change Biology, (December 2018), 1-7. 626 https://doi.org/10.1111/gcb.14559

627 Baldocchi, D., Chu, H., \& Reichstein, M. (2018). Inter-annual variability of net and gross 628 ecosystem carbon fluxes: A review. Agricultural and Forest Meteorology, 249, 520-533. https://doi.org/10.1016/j.agrformet.2017.05.015

630

631

632

633

634

635

636

637

638

639

640

641

642

643

644

645

646

647

648

649

650

651

652

653

654

655

656

Barba, J., Cueva, A., Bahn, M., Barron-Gafford, G. A., Bond-Lamberty, B., Hanson, P. J., Jaimes, A., Kulmala, L., Pumpanen, J., Scott, R. L., Wohlfahrt, G., \& Vargas, R. (2018). Comparing ecosystem and soil respiration: Review and key challenges of tower-based and soil measurements. Agricultural and Forest Meteorology, 249, 434443. https://doi.org/10.1016/j.agrformet.2017.10.028

Barford, C. C., Wofsy, S. C., Goulden, M. L., Munger, J. W., Pyle, E. H., Urbanski, S. P., Hutyra, L., Saleska, S. R., Fitzjarrald, D., \& Moore, K. (2001). Factors Controlling Long- and Short-Term Sequestration of Atmospheric CO 2 in a. Science, 294(November), 1688-1691. https://doi.org/http://dx.doi.org/10.1126/science.1062962

Berman, E. S., Fladeland, M., Liem, J., Kolyer, R., \& Gupta, M. (2012). Greenhouse gas analyzer for measurements of carbon dioxide, methane, and water vapor aboard an unmanned aerial vehicle. Sensors and Actuators B. https://doi.org/10.1016/j.snb.2012.04.036

Bielewski, J., \& Śliwka, I. (2014). Variation of CFCs and SF6 concentration in air of Urban Area, Kraków (Poland). In Acta Physica Polonica A (Vol. 125, pp. 895-897). https://doi.org/10.12693/APhysPolA.125.895

Bond-Lamberty, B., \& Thomson, a. (2010). A global database of soil respiration data. Biogeosciences, 7(6), 1915-1926. https://doi.org/10.5194/bg-7-1915-2010

Bond-Lamberty, B., Bailey, V. L., Chen, M., Gough, C. M., \& Vargas, R. (2018). Globally rising soil heterotrophic respiration over recent decades. Nature. https://doi.org/10.1038/s41586-018-0358-x

Brailsford, G. (2012). GAW Report No . 206 16th WMO / IAEA Meeting on Carbon Dioxide , Other Greenhouse Gases, and Related Measurement Techniques ( GGMT2011 ). Retrieved from https://library.wmo.int/pmb_ged/gaw_206.pdf

Burba, G. (2013). Eddy Covariance Method for Scientific, Industrial, Agricultural, and Regulatory Applications: Eddy Covariance Method for Scientific, Industrial, Agricultural, 
657

658

659

660

661

662

663

664

665

666

667

668

669

670

671

672

673

674

675

676

677

678

679

680

681

682

683

684

685

686

687

688

and Regulatory Applications: A Field Book on Measuring Ecosystem Gas Exchange and Areal Emission. LI-COR Biosciences: LI-COR Biosciences, Lincoln, NE, USA.

Burba, G., Madsen, R., \& Feese, K. (2013). Eddy Covariance Method for CO2 Emission Measurements in CCUS Applications: Principles, Instrumentation and Software. Energy Procedia, 40, 329-336. https://doi.org/10.1016/j.egypro.2013.08.038

California Air Resources Board. (n.d.). ARB approved growth models. Retrieved from https://www.arb.ca.gov/cc/capandtrade/protocols/usforest/usforest-models.htm

California Air Resources Board. (2011). Compliance Offset Protocol U.S. Forest Projects. Retrieved from https://www.arb.ca.gov/regact/2010/capandtrade10/copusforest.pdf

California Air Resources Board. (2013). Technical Guidance for Offset Verifiers Verification of Offset Project Data Reports. Retrieved September 12, 2018, from https://www.arb.ca.gov/cc/capandtrade/offsets/offset-verification-guidance.pdf

California Air Resources Board. (2014). Compliance Offset Protocol U.S. Forest Projects. Retrieved from https://www.arb.ca.gov/regact/2014/capandtrade14/ctusforestprojectsprotocol.pdf

California Air Resources Board. (2015a). California Air Resources Board Offset Credit Regulatory Conformance and Invalidation Guidance. Retrieved from https://www.arb.ca.gov/cc/capandtrade/offsets/arboc_guide_regul_conform_invali dation.pdf

California Air Resources Board. (2015b). Compliance Offset Protocol US Forest Projects. Retrieved from https://www.arb.ca.gov/cc/capandtrade/protocols/usforest/forestprotocol2015.pdf

California Air Resources Board. (2018a). Air Resources Board Offset Credits Issued.

\section{Retrieved from}

https://www.arb.ca.gov/cc/capandtrade/offsets/issuance/arb_offset_credit_issuance _table.pdf

California Air Resources Board. (2018b). ARB offsets Issued. Retrieved from https://www.arb.ca.gov/cc/capandtrade/offsets/issuance/arb_offset_credit_issuance _table.pdf

California Air Resources Board. (2018c). PROPOSED ENDORSEMENT OF CALIFORNIA TROPICAL FOREST STANDARD: Final Environmental Analysis. PROPOSED ENDORSEMENT OF CALIFORNIA TROPICAL FOREST STANDARD: 
689

690

691

692

693

694

695

696

697

698

699

700

701

702

703

704

705

706

707

708

709

710

711

712

713

714

715

716

717

718

719

720

721

Final Environmental Analysis. Retrieved from https://ww3.arb.ca.gov/cc/ghgsectors/tropicalforests/final_ea_ca_tropical_forest_sta ndard.pdf

CARB. (2015). Early Action Projects. Retrieved from http://www.arb.ca.gov/cc/capandtrade/offsets/earlyaction/projects.htm

CARB Air Resources Board. Title 17, California Code of Regulations, to read as follows : Article 5 : CALIFORNIA CAP ON GREENHOUSE GAS EMISSIONS AND MARKET-BASED COMPLIANCE MECHANISMS TO ALLOW FOR THE USE OF COMPLIANCE INSTRUMENTS ISSUED BY LINKED JURISDICTIONS Note : Unofficial (2013). Retrieved from https://ww3.arb.ca.gov/cc/capandtrade/ctlinkqc.pdf

Cawrse, D., Keyser, C., Keyser, T., Sanchez, A., Smith-Mateja, E., \& Van Dyck, M. (2009). Forest Vegetation Simulator Model Validation Protocols. Fort Collins, CO: USDA - Forest Service, Forest Management Service Center, (January), 1-10. Retrieved from https://www.fs.fed.us/fmsc/ftp/fvs/docs/steering/FVS_Model_Validation_Protocols. pdf

Chapin, F. S., Woodwell, G. M., Randerson, J. T., Rastetter, E. B., Lovett, G. M., Baldocchi, D. D., Clark, D. a., Harmon, M. E., Schimel, D. S., Valentini, R., Wirth, C., Aber, J. D., Cole, J. J., Goulden, M. L., Harden, J. W., Heimann, M., Howarth, R. W., ... Schulze, E. D. (2006). Reconciling carbon-cycle concepts, terminology, and methods. Ecosystems, 9(7), 1041-1050. https://doi.org/10.1007/s10021-005-0105-7

Climate Action Reserve. (2018a). Climate Action Reserve Projects. Retrieved from http://www.climateactionreserve.org/

Climate Action Reserve. (2018b). Forest Project Protocol Version 4.0. Retrieved from http://www.climateactionreserve.org/how/protocols/forest/dev/version-4-0/

Comeau, L.-P., Lai, D. Y. F., Cui, J. J., \& Farmer, J. (2018). Separation of soil respiration: a site-specific comparison of partition methods. SOIL, 4(2), 141-152. https://doi.org/10.5194/soil-4-141-2018

Curtis, P. S., \& Gough, C. M. (2018, September). Forest aging, disturbance and the carbon cycle. New Phytologist. https://doi.org/10.1111/nph.15227

Curtis, P. S., Hanson, P. J., Bolstad, P., Barford, C., Randolph, J. C., Schmid, H. P., \& Wilson, K. B. (2002). Biometric and eddy-covariance based estimates of annual 
722

723

724

725

726

727

728

729

730

731

732

733

734

735

736

737

738

739

740

741

742

743

744

745

746

747

748

749

750

751

752

carbon storage in five eastern North American deciduous forests. Agricultural and Forest Meteorology, 113(1-4), 3-19. https://doi.org/10.1016/S0168-1923(02)00099-0

Dai, S. Q., Li, H., Xiong, J., Ma, J., Guo, H. Q., Xiao, X., \& Zhao, B. (2018). Assessing the Extent and Impact of Online Data Sharing in Eddy Covariance Flux Research. Journal of Geophysical Research: Biogeosciences. https://doi.org/10.1002/2017JG004277

Davidson, E. A., \& Janssens, I. A. (2006). Temperature sensitivity of soil carbon decomposition and feedbacks to climate change. Nature, 440(7081), 165-173. https://doi.org/10.1038/nature04514

DiRocco, T., Ramage, B., Evans, S., \& Potts, M. (2014). Accountable Accounting: CarbonBased Management on Marginal Lands. Forests, 5(4), 847-861. https://doi.org/10.3390/f5040847

Düdder, B., \& Ross, O. (2017). Timber tracking: Reducing complexity of due diligence by using blockchain technology (position paper). In CEUR Workshop Proceedings (Vol. 1898). https://doi.org/10.2139/ssrn.3015219

Dunlop, J., Winner, T. P., \& Smith, J. B. (2019). M-RCBG Associate Working Paper Series I No. 120 California Compliance Offsets: Problematic Protocols and Buyer Behavior.

Retrieved from www.hks.harvard.edu/mrcbg

Eaton, F. (2014). Howland Research Forest CAR 681 Verification Report. Retrieved from https://hereserve2.apx.com/mymodule/reg/TabDocuments.asp?r=111\&ad=Prpt\&ac $\mathrm{t}=$ update\&type $=$ PRO\&aProj $=$ pub\&tablename $=$ doc\&id $1=681$

Eddy Covariance. (2012). https://doi.org/10.1007/978-94-007-2351-1

"Fluxnet." (n.d.). Home | fluxnetweb.ornl.gov. Retrieved from https://fluxnet.ornl.gov/

FLUXNET. (n.d.). Fluxnet Database. Retrieved from http://fluxnet.fluxdata.org/

Foss, P.-K. (2018). The Offce of the Auditor General of Norway's investigation of Norway's International Climate and Forest Initiative, Document 3:10 (2017-2018). Retrieved from www.riksrevisjonen.no

Giasson, M. A., Ellison, A. M., Bowden, R. D., Crill, P. M., Davidson, E. A., Drake, J. E., Frey, S. D., Hadley, J. L., Lavine, M., Melillo, J. M., Munger, J. W., Nadelhoffer, K. J., Nicoll, L., Ollinger, S. V., Savage, K. E., Steudler, P. A., Tang, J., ... Finzi, A. C. (2013). Soil respiration in a northeastern US temperate forest: A 22-year synthesis. Ecosphere, 4(11). https://doi.org/10.1890/ES13.00183.1

Peer) reviewing PDF | (2019:04:36538:2:0:NEW 31 Jul 2019) 
753 Göckede, M., Kwon, M. J., Kittler, F., Heimann, M., Zimov, N., \& Zimov, S. (2019).

754

755

756

757

758

759

760

761

762

763

764

765

766

767

768

769

770

771

772

773

774

775

776

777

778

779

780

781

782

783

784

785

Negative feedback processes following drainage slow down permafrost degradation. Global Change Biology. https://doi.org/10.1111/gcb.14744

Gonçalves, F., Treuhaft, R., Law, B., Almeida, A., Walker, W., Baccini, A., dos Santos, J. R., \& Graça, P. (2017). Estimating aboveground biomass in tropical forests: Field methods and error analysis for the calibration of remote sensing observations. Remote Sensing. https://doi.org/10.3390/rs9010047

Hagen, S. C., Braswell, B. H., Linder, E., Frolking, S., Richardson, a. D., \& Hollinger, D. Y. (2006). Statistical uncertainty of eddy flux-based estimates of gross ecosystem carbon exchange at Howland Forest, Maine. Journal of Geophysical Research, 111(D8), 1-12. https://doi.org/10.1029/2005JD006154

Hammrick, K., \& Gallant, M. (2017). Fertile Ground State of Forest Carbon Finance 2017. Retrieved from https://www.forest-trends.org/wpcontent/uploads/2018/01/doc_5715.pdf

Haya, B. (2019). POLICY BRIEF: The California Air Resources Board's U.S. Forest offset protocol underestimates leakage. Berkeley, CA. Retrieved from https://gspp.berkeley.edu/assets/uploads/research/pdf/Policy_BriefUS_Forest_Projects-Leakage-Haya_2.pdf

Haya, B., Strong, A., Grubert, E., \& Cullenward, D. (2016). Carbon offsets in California: Science in the policy development process. In Advances in Natural and Technological Hazards Research (Vol. 45, pp. 241-254). Springer International Publishing. https://doi.org/10.1007/978-3-319-20161-0_15

Hein, J., Guarin, A., Frommé, E., \& Pauw, P. (2018). Deforestation and the Paris climate agreement: An assessment of REDD + in the national climate action plans. Forest Policy and Economics, 90, 7-11. https://doi.org/10.1016/J.FORPOL.2018.01.005

Hicks Pries, C. E., Castanha, C., Porras, R., \& Torn, M. S. (2017). The whole-soil carbon flux in response to warming. Science, 1319(March 2017), 1-9. https://doi.org/10.1126/science.aal1319

Holdaway, R. J., McNeill, S. J., Mason, N. W. H., \& Carswell, F. E. (2014). Propagating Uncertainty in Plot-based Estimates of Forest Carbon Stock and Carbon Stock Change. Ecosystems, 17(4), 627-640. https://doi.org/10.1007/s10021-014-9749-5

Hollinger, D., Aber, J., Dail, B., Davidson, E. A., Goltz, S. M., Hughes, H., Leclerc, M. Y., Lee, J. T., Richardson, A. D., Rodrigues, C., Scott, N. A., Achuatavarier, D., \&

Peer) reviewing PDF | (2019:04:36538:2:0:NEW 31 Jul 2019) 
786

787

788

789

790

791

792

793

794

795

796

797

798

799

800

801

802

803

804

805

806

807

808

809

810

811

812

813

814

815

816

817

818

819

Walsh, J. (2004). Spatial and temporal variability in forest-atmosphere CO2 exchange. Global Change Biology, 10(10), 1689-1706. https://doi.org/10.1111/j.13652486.2004.00847.x

Hollinger, D., Davidson, E. A., Richardson, A. D., Dail, D. B., \& Scott, N. (2013). Using model analyses and surface-atmosphere exchange measurements from the Howland AmeriFlux Site in Maine, USA, to improve understanding of forest ecosystem C cycling. Argonne, IL (United States). https://doi.org/10.2172/1069294

Hollinger, D., Davidson, E., Dail, D. B., \& Richardson, A. (2016). Final Technical Report. Supporting carbon cycle and earth systems modeling with measurements and analysis from the Howland AmeriFlux Site. Argonne, IL (United States). https://doi.org/10.2172/1234261

Hopkinson, C., Chasmer, L., Barr, A. G., Kljun, N., Black, T. A., \& McCaughey, J. H. (2016). Monitoring boreal forest biomass and carbon storage change by integrating airborne laser scanning, Biometry and eddy covariance data. Remote Sensing of Environment, 181, 82-95. https://doi.org/10.1016/j.rse.2016.04.010

Hurst, D. F., Bakwin, P. S., \& Elkins, J. W. (1998). Recent trends in the variability of halogenated trace gases over the United States. JOURNAL OF GEOPHYSICAL RESEARCH (Vol. 103). https://doi.org/10.1029/98JD01879

Kagombe, J. K., Cheboiwo, J. K., Gichu, A., Handa, C., \& Wamboi, J. (2018). Payment for Environmental Services: Status and Opportunities in Kenya. Journal of Resources Development and Management Journal, 40. Retrieved from http://www.kefri.org/wpcontent/uploads/PDF/Publications/Journal Paper on PES Experience in Kenya 2018.pdf

Keesstra, S., Nunes, J., Novara, A., Finger, D., Avelar, D., Kalantari, Z., \& Cerdà, A. (2018). The superior effect of nature based solutions in land management for enhancing ecosystem services. Science of The Total Environment, 610-611, 997-1009. https://doi.org/10.1016/j.scitotenv.2017.08.077

Kollmuss, A., \& Fussler, J. (2015). Overview of carbon offset programs: Similarities and differences. Partnership for Market Readiness (PMR) Technical Note (Vol. 6). Washington, DC. Retrieved from https://www.thepmr.org/system/files/documents/PMR Technical Note 6_Offsets_0.pdf

Kumar, J., Hoffman, F. M., Hargrove, W. W., \& Collier, N. (2016). Understanding the representativeness of FLUXNET for upscaling carbon flux from eddy covariance

Peer) reviewing PDF | (2019:04:36538:2:0:NEW 31 Jul 2019) 
820

821

822

823

824

825

826

827

828

829

830

831

832

833

834

835

836

837

838

839

840

841

842

843

844

845

846

847

848

849

850

851

852

853

measurements. Earth System Science Data Discussions, (August), 1-25. https://doi.org/10.5194/essd-2016-36

Kutsch, W. L., Heiskanen, J., Vermeulen, A., Juurola, E., Rivier, L., Papale, D., Johannessen, T., Jordan, A., \& Hammer, S. (2018). ICOS and global initiatives working towards policy-relevant, coordinated carbon and greenhouse gas observations. 20th EGU General Assembly, EGU2018, Proceedings from the Conference Held 4-13 April, 2018 in Vienna, Austria, p.12711, 20, 12711. Retrieved from http://adsabs.harvard.edu/abs/2018EGUGA..2012711K

Lee, X. (2017). Principle of Eddy Covariance (pp. 149-173). Springer, Cham. https://doi.org/10.1007/978-3-319-60853-2_8

Li, L., McMurray, A., Xue, J., Liu, Z., \& Sy, M. (2018). Industry-wide corporate fraud: The truth behind the Volkswagen scandal. Journal of Cleaner Production, 172, 31673175. https://doi.org/10.1016/j.jclepro.2017.11.051

Li, W., Ciais, P., Wang, Y., Yin, Y., Peng, S., Zhu, Z., Bastos, A., Yue, C., Ballantyne, A. P., Broquet, G., Canadell, J. G., Cescatti, A., Chen, C., Cooper, L., Friedlingstein, P., Le Quéré, C., Myneni, R. B., \& Piao, S. (2018). Recent Changes in Global Photosynthesis and Terrestrial Ecosystem Respiration Constrained From Multiple Observations. Geophysical Research Letters, 45(2), 1058-1068. https://doi.org/10.1002/2017GL076622

Liu, S., Zhuang, Q., He, Y., Noormets, A., Chen, J., \& Gu, L. (2016). Evaluating atmospheric $\mathrm{CO} 2$ effects on gross primary productivity and net ecosystem exchanges of terrestrial ecosystems in the conterminous United States using the AmeriFlux data and an artificial neural network approach. Agricultural and Forest Meteorology. https://doi.org/10.1016/j.agrformet.2016.01.007

Luyssaert, S., Reichstein, M., Schulze, E. D., Janssens, I. A., Law, B. E., Papale, D., Dragoni, D., Goulden, M. L., Granier, A., Kutsch, W. L., Linder, S., Matteucci, G., Moors, E., Munger, J. W., Pilegaard, K., Saunders, M., \& Falge, E. M. (2009). Toward a consistency cross-check of eddy covariance flux-based and biometric estimates of ecosystem carbon balance. Global Biogeochemical Cycles, 23(3), n/a-n/a. https://doi.org/10.1029/2008GB003377

Marland, E., Domke, G., Hoyle, J., Marland, G., Bates, L., Helms, A., Jones, B., Kowalczyk, T., Ruseva, T. B., \& Szymanski, C. (2017). Understanding and Analysis: The California Air Resources Board Forest Offset Protocol. https://doi.org/10.1007/978-3319-52434-4 
854 Masciandaro, G., Macci, C., Peruzzi, E., \& Doni, S. (2018). Soil Carbon in the World:

855

856

857

858

859

860

861

862

863

864

865

866

867

868

869

870

871

872

873

874

875

876

877

878

879

880

881

882

883

884

885

886

887

Ecosystem Services Linked to Soil Carbon in Forest and Agricultural Soils. The

Future of Soil Carbon, 1-38. https://doi.org/10.1016/B978-0-12-811687-6.00001-8

McFarland, B. J. (2018). Green Bonds, Landscape Bonds, and Rainforest Bonds. Conservation of Tropical Rainforests, 609-641. https://doi.org/10.1007/978-3-319-63236$0 \_16$

Melillo, J. M., Butler, S., Johnson, J., Mohan, J., Steudler, P., Lux, H., Burrows, E., Bowles, F., Smith, R., Scott, L., Vario, C., Hill, T., Burton, A., Zhou, Y.-M., \& Tang, J. (2011). Soil warming, carbon-nitrogen interactions, and forest carbon budgets. Proceedings of the National Academy of Sciences, 108(23), 9508-9512. https://doi.org/10.1073/pnas.1018189108

Mesoamerican Alliance of Peoples and Forests (MAPF). (2015). Tropical forest carbon in indigenous territories: a global analysis. Retrieved from http://www.alianzamesoamericana.org/wp-content/uploads/2015/11/TropicalForest-Carbon-in-Indigenous-Territories-A-Global-Analysis.pdf

Metzger, S., Junkermann, W., Mauder, M., Beyrich, F., Butterbach-Bahl, K., Schmid, H. P., \& Foken, T. (2012). Eddy-covariance flux measurements with a weight-shift microlight aircraft. Atmospheric Measurement Techniques. https://doi.org/10.5194/amt-5-1699-2012

Newman, P. A. (2018). The way forward for Montreal Protocol science. Comptes Rendus Geoscience. https://doi.org/10.1016/J.CRTE.2018.09.001

Ney, P., Graf, A., Bogena, H., Diekkrüger, B., Drüe, C., Esser, O., Heinemann, G., Klosterhalfen, A., Pick, K., Pütz, T., Schmidt, M., Valler, V., \& Vereecken, H. (2019). $\mathrm{CO} 2$ fluxes before and after partial deforestation of a Central European spruce forest. Agricultural and Forest Meteorology, 274, 61-74. https://doi.org/10.1016/j.agrformet.2019.04.009

Nicolini, G., Aubinet, M., Feigenwinter, C., Heinesch, B., Lindroth, A., Mamadou, O., Moderow, U., Mölder, M., Montagnani, L., Rebmann, C., \& Papale, D. (2018). Impact of $\mathrm{CO} 2$ storage flux sampling uncertainty on net ecosystem exchange measured by eddy covariance. Agricultural and Forest Meteorology. https://doi.org/10.1016/j.agrformet.2017.09.025

Novick, K. A., Biederman, J. A., Desai, A. R., Litvak, M. E., Moore, D. J. P., Scott, R. L., \& Torn, M. S. (2018). The AmeriFlux network: A coalition of the willing. Agricultural and Forest Meteorology, 249, 444-456.

Peer) reviewing PDF | (2019:04:36538:2:0:NEW 31 Jul 2019) 
888

889

890

891

892

893

894

895

896

897

898

899

900

901

902

903

904

905

906

907

908

909

910

911

912

913

914

915

916

917

918

919

920

https://doi.org/10.1016/J.AGRFORMET.2017.10.009

Nunez, F. California Global Warming Solutions Act, 2016., Pub. L. No. AB32 (2016).

Retrieved from https://www.arb.ca.gov/cc/ab32/\%0Aab32.htm

Ocheltree, T. W., Loescher, H. W., Ocheltree, T. W., \& Loescher, H. W. (2007). Design of the AmeriFlux Portable Eddy Covariance System and Uncertainty Analysis of Carbon Measurements. Journal of Atmospheric and Oceanic Technology, 24(8), 13891406. https://doi.org/10.1175/JTECH2064.1

Ouimette, A. P., Ollinger, S. V., Richardson, A. D., Hollinger, D. Y., Keenan, T. F., Lepine, L. C., \& Vadeboncoeur, M. A. (2018). Carbon fluxes and interannual drivers in a temperate forest ecosystem assessed through comparison of top-down and bottom-up approaches. Agricultural and Forest Meteorology. https://doi.org/10.1016/j.agrformet.2018.03.017

Palmer, P. I., Doherty, S., Allen, G., Bower, K., Bösch, H., Chipperfield, M. P., Connors, S., Dhomse, S., Feng, L., Finch, D. P., Gallagher, M. W., Gloor, E., Gonzi, S., Harris, N. R. P., Helfter, C., Humpage, N., Kerridge, B., ... Young, D. (2018). A measurement-based verification framework for UK greenhouse gas emissions: an overview of the Greenhouse gas Uk and Global Emissions (GAUGE) project. Atmospheric Chemistry and Physics Discussions, 5194, 1-52. https://doi.org/10.5194/acp-2018-135

Papale, D., \& Valentini, R. (2003). A new assessment of European forests carbon exchanges by eddy fluxes and artificial neural network spatialization. Global Change Biology, 9(4), 525-535. https://doi.org/10.1046/j.1365-2486.2003.00609.x

Paré, D., Gertner, G. Z., Bernier, P. Y., \& Yanai, R. D. (2016). Quantifying uncertainty in forest measurements and models: approaches and applications. Canadian Journal of Forest Research, 46(3), v-v. https://doi.org/10.1139/cjfr-2016-0029

Peters-Stanley, M., Hamilton, K., Yin, D., Castillo, S., \& Norman, M. (2012). Ecosystem Marketplace Leveraging the Landscape. Retrieved December 1, 2018, from www.ecosystemmarketplace.com

Ramos-Castillo, A., Castellanos, E. J., \& Galloway McLean, K. (2017). Indigenous peoples, local communities and climate change mitigation. Climatic Change, 140(1). https://doi.org/10.1007/s10584-016-1873-0

Ran, Y., Li, X., Sun, R., Kljun, N., Zhang, L., Wang, X., \& Zhu, G. (2016). Spatial representativeness and uncertainty of eddy covariance carbon flux measurements 
921

922

923

924

925

926

927

928

929

930

931

932

933

934

935

936

937

938

939

940

941

942

943

944

945

946

947

948

949

950

951

952

953

for upscaling net ecosystem productivity to the grid scale. Agricultural and Forest Meteorology. https://doi.org/10.1016/j.agrformet.2016.05.008

Reis, L. P., de Souza, A. L., dos Reis, P. C. M., Mazzei, L., Soares, C. P. B., Miquelino Eleto Torres, C. M., da Silva, L. F., Ruschel, A. R., Rêgo, L. J. S., \& Leite, H. G. (2018). Estimation of mortality and survival of individual trees after harvesting wood using artificial neural networks in the amazon rain forest. Ecological Engineering, 112, 140-147. https://doi.org/10.1016/J.ECOLENG.2017.12.014

Van Renssen, S. (2018). The inconvenient truth of failed climate policies. Nature Climate Change, 8(5), 355-358. https://doi.org/10.1038/s41558-018-0155-4

Richardson, A. D., Aubinet, M., Barr, A. G., Hollinger, D. Y., Ibrom, A., Lasslop, G., \& Reichstein, M. (2012). Eddy Covariance. (M. Aubinet, T. Vesala, \& D. Papale, Eds.). Dordrecht: Springer Netherlands. https:/doi.org/10.1007/978-94-007-2351-1

Richardson, A. D., Hollinger, D. Y., Shoemaker, J. K., Hughes, H., Savage, K., \& Davidson, E. A. (2019). Six years of ecosystem-atmosphere greenhouse gas fluxes measured in a sub-boreal forest. Scientific Data, 6(1), 117.

https://doi.org/10.1038/s41597-019-0119-1

Rocha, A. V., \& Shaver, G. R. (2011). Burn severity influences postfire $\mathrm{CO}_{2}$ exchange in arctic tundra. Ecological Applications, 21(2), 477-489. https://doi.org/10.1890/100255.1

Sabbaghi, O., \& Sabbaghi, N. (2017). The Chicago Climate Exchange and market efficiency: an empirical analysis. Environmental Economics and Policy Studies, 19(4), 711-734. https://doi.org/10.1007/s10018-016-0171-4

Schatzki, T., Stavins, R. N., \& Hall, W. (2018). Key Issues Facing California's GHG Cap-andTrade System for 2021-2030. Working Paper Series. Cambridge, MA. Retrieved from www.mrcbg.org

Schneider, L., \& La Hoz Theuer, S. (2018, September 21). Environmental integrity of international carbon market mechanisms under the Paris Agreement. Climate Policy, pp. 1-15. https://doi.org/10.1080/14693062.2018.1521332

Schultz, M. G., Akimoto, H., Bottenheim, J., Buchmann, B., Galbally, I. E., Gilge, S., Helmig, D., Koide, H., Lewis, A. C., Novelli, P. C., Plass-Dülmer, C., Ryerson, T. B., Steinbacher, M., Steinbrecher, R., Tarasova, O., Tørseth, K., Thouret, V., \& Zellweger, C. (2015). The Global Atmosphere Watch reactive gases measurement network. Elem Sci Anth, 3, 67. https://doi.org/10.12952/journal.elementa.000067

Peer) reviewing PDF | (2019:04:36538:2:0:NEW 31 Jul 2019) 
954

955

956

957

958

959

960

961

962

963

964

965

966

967

968

969

970

971

972

973

974

975

976

977

978

979

980

981

982

983

984

985

Stanley, K. M., Grant, A., O'doherty, S., Young, D., Manning, A. J., Stavert, A. R., Spain, T. G., Salameh, P. K., Harth, C. M., Simmonds, P. G., Sturges, W. T., Oram, D. E., \& Derwent, R. G. (2018). Greenhouse gas measurements from a UK network of tall towers: technical description and first results. Atmos. Meas. Tech, 11, 1437-1458. https://doi.org/10.5194/amt-11-1437-2018

Subashini, M. M., Das, S., Heble, S., Raj, U., \& Karthik, R. (2018). Internet of things based wireless plant sensor for smart farming. Indonesian Journal of Electrical Engineering and Computer Science, 10(2), 456-468. https://doi.org/10.11591/ijeecs.v10.i2.pp456-468

UNFCCC. (2017). Second Biennial Update Report of Brazil. Retrieved from https://unfccc.int/files/national_reports/nonannex_i_parties/biennial_update_reports/application/pdf/bur2-ing02032017_final.pdf

United Nations Framework Convention on Climate Change (UNFCCC). (n.d.). UNREDD Programme. Retrieved from http://www.un-redd.org/

US-Ho1: Howland Forest (main tower). (n.d.). Retrieved from https://ameriflux.lbl.gov/sites/siteinfo/US-Ho1

Verified Carbon Standard. (2018). Retrieved from https://verra.org/

VERRA. (2015). VM0007 REDD+ Methodology Framework (REDD-MF), v1.5. Retrieved from http://verra.org/methodology/vm0007-redd-methodology-framework-reddmf-v1-5/

Vitale, D., \& Papale, D. (2017). Towards an integrated quality control procedure for eddy-covariance data. 19th EGU General Assembly, EGU2017, Proceedings from the Conference Held 23-28 April, 2017 in Vienna, Austria., p.16089, 19, 16089. Retrieved from http://adsabs.harvard.edu/abs/2017EGUGA..1916089V

Wang, X., Liu, L., Piao, S., Janssens, I. a, Tang, J., Liu, W., Chi, Y., Wang, J., \& Xu, S. (2014). Soil respiration under climate warming: differential response of heterotrophic and autotrophic respiration. Global Change Biology, 1-9. https://doi.org/10.1111/gcb.12620

Warnecke, C. (2014). Can CDM monitoring requirements be reduced while maintaining environmental integrity? Climate Policy, 14(4), 443-466. https://doi.org/10.1080/14693062.2014.875285 
986 Warner, D. L., Guevara, M., Inamdar, S., \& Vargas, R. (2019). Upscaling soil-atmosphere

987

988

989

990

991

992

993

994

995

996

997

998

999

1000

1001

1002

1003

1004

1005

1006

1007

1008

1009

1010

1011

1012

1013

1014

1015 $\mathrm{CO} 2$ and $\mathrm{CH} 4$ fluxes across a topographically complex forested landscape. Agricultural and Forest Meteorology, 264, 80-91. https://doi.org/10.1016/j.agrformet.2018.09.020

Winrock International. (2016). American Carbon Registry Offset Registry. Retrieved October 19, 2016, from https://acr2.apx.com/mymodule/mypage.asp

World Bank and Ecofys. (2018). State and Trends of Carbon Pricing 2018. https://doi.org/Doi: 10.1596/978-1-4648-1292-7.

Wutzler, T., Lucas-Moffat, A., Migliavacca, M., Knauer, J., Sickel, K., Šigut, L., Menzer, O., \& Reichstein, M. (2018). Basic and extensible post-processing of eddy covariance flux data with REddyProc. Biogeosciences, 15(16), 5015-5030. https://doi.org/10.5194/bg-15-5015-2018

Yang, G.-M., Cheng, C.-F., Jiang, W., Lu, Z.-T., Purtschert, R., Sun, Y.-R., Tu, L.-Y., \& $\mathrm{Hu}$, S.-M. (2013). Analysis of 85Kr: a comparison at the 10-14 level using micro-liter samples. Scientific Reports, 3, 31-33. https://doi.org/10.1038/srep01596

Yu, R., Ruddell, B. L., Kang, M., Kim, J., \& Childers, D. (2019). Anticipating global terrestrial ecosystem state change using FLUXNET. Global Change Biology, 25(7), 2352-2367. https://doi.org/10.1111/gcb.14602

\section{Author Contribution Statements}

B.D.V.M. conceived the research, developed and wrote the manuscript; M.M. performed the statistical analysis; A.D. constructed the interactive map.

\section{Additional Information}

Supplementary information accompanies this paper.

Competing Interests: The authors declare no competing interest.

\section{Acknowledgements:}

This work used eddy covariance data acquired and shared by the FLUXNET community, including potentially data from these networks: AmeriFlux, AfriFlux, AsiaFlux, CarboAfrica, CarboEuropeIP, CarboItaly, CarboMont, ChinaFlux, FluxnetCanada, GreenGrass, ICOS, KoFlux, LBA, NECC, OzFlux-TERN, TCOS-Siberia, and 
1016 USCCC. The ERA-Interim reanalysis data are provided by ECMWF and processed by

1017 LSCE. The FLUXNET eddy covariance data processing and harmonization was carried 1018 out by the European Fluxes Database Cluster, AmeriFlux Management Project, and 1019 Fluxdata project of FLUXNET, with the support of CDIAC and ICOS Ecosystem 1020 Thematic Center, and the OzFlux, ChinaFlux and AsiaFlux offices.

${ }^{i}$ The concentration of $\mathrm{CO}_{2}$ that would cause the same amount of radiative forcing as a given mixture of $\mathrm{CO}_{2}$ and other greenhouse gases.

ii percentaage error $=\frac{\mid \text { Estimated value }- \text { NEE1 value } \mid}{\text { NEE1 value }} \times 100$

Where estimated value $=$ CARB-CAR, and NEE1 value $=$ directly measured value.

We propose recalculation of material misstatement errors based on NEE values as follows:

Percent error determination for offsets based on the material misstatement equation (CARB Air Resources Board, 2013) is defined as follows:

$\%$ error $=\sum\left[\frac{\text { Discrepancies }+ \text { Omissions }+ \text { Misreporting }}{\text { Total reported emissions }}\right] \times 100 \%$.

Simplifying, where Discrepancies are defined as the CARB-CAR value, Total reported emissions are defined as NEE1 reported emissions, NEE1 represents the accepted value, and Omissions and Misreporting $=0$, the expression simplifies as,

$$
\text { percentaage error }=\frac{\mid C A R B_{C A R}-N E E \text { value } \mid}{N E E 1 \text { value }} \times 100
$$

iii CARB-CAR. The 63 project types include avoided conversion $(A C, n=7)$, reforestation $(R F, n=2)$, and improved forest management (IFM, $\mathrm{n}=54$ ) projects (Table I). AC and RF projects involve temperate zone historically forested areas and must maintain forest stocks through CARB-CAR regulatory practices (California Air Resources Board, 2011, 2014, 2015b). Reforestation projects involve land that has been deforested (e.g., canopy cover less than 105) and is actively replanted with trees. Details of management practices for each site vary, however, all sites comply with prohibition of clear-cut (e.g., < 40 acres harvested), broadcast fertilization, extensive soil disturbance and extensive short harvest rotations typical of timber plantations, ensuring comparability of baseline management practices and application of the compliance protocol process as regulated by the CARB-CAR protocols (California Air Resources Board, 2011, 2014, 2015b). Aggressive management practices involving timber removal would trend towards more positive CARB-CAR values (e.g., net positive emissions to the atmosphere) rendering the CARB-CAR data base conservative for comparison with NEE values. The IFM and AC projects $(n=61)$ are subject to similar land management activities, including minimal harvesting, as defined by the protocols. CARB-CAR net forest carbon sequestration for the 63 projects is characterized by a mean and standard deviation of -948.8 $\pm 1,504.8$ (Results section 3.1). 
Descriptive reports and cumulative emissions data are derived from the CAR website homepage (Climate Action Reserve, 2018a). Forest carbon results for the American Carbon Registry ("American Carbon Registry," 2018) and the Verified Carbon Standard ("Verified Carbon Standard," 2018), both approved project registries by the ARB (California Air Resources Board, 2018b), were reviewed but were not included in this study. ACR project data was not available in summary format for carbon offsets presenting a challenge to verify ACR results. A total of 55 ACR forest carbon projects were listed as of 09-01-2018; 18 identify values for registered carbon credits but serial numbers for ARB issued offsets were not available ("American Carbon Registry," 2018). Analysis of the ACR Part VII forest project listing applications, identical to those for CARB-CAR applications, verified that soil carbon was not included in the carbon pools employed in net forest carbon estimations $(\mathrm{n}=30: 189,173,192,199,202,211,298,249,200,256,265$, $266,267,268,262,265,255,276,282,282,273,274,284,288,292,303,324,360,277,278$.). The VCS identified 12 proposed forest projects, however, offset credit summaries and serial numbers for ARB issued offsets were not available. Based on the information available, ACR and VCS results were not considered in this study.

CARB-CAR defines forests in terms of photosynthesis and carbon stored in soils and litter. A forest project is a planned set of activities designed to increase removals of $\mathrm{CO}_{2}$ from the atmosphere, or reduce or prevent emissions of $\mathrm{CO}_{2}$ to the atmosphere, through increasing and/or conserving forest carbon stocks. A net climate benefit, or verification of a net negative $\mathrm{CO}_{2}$ balance for the forest ecosystem must result from the project activities. The Offset Project Boundary defines GHG emission sources, GHG sinks, and GHG reservoirs that must be accounted for and quantified for a Forest Project's GHG reductions and removal enhancements. Tables in the CARB-CAR protocols provide a comprehensive list of project components that must be included in the Offset Project Boundary for each type of Forest Project. A "reservoir/pool" is accounted for by quantifying changes in carbon stock levels. GHG sources or GHG sinks, GHG reductions and GHG removal enhancements are accounted for by quantifying changes in GHG emission or GHG removal enhancement rates. The CARB protocols and accounting requirements are described in three related primary documents published in 2011 (California Air Resources Board, 2014), 2014 (California Air Resources Board, 2014) and 2015 (California Air Resources Board, 2015b) entitled: "Compliance Offset Protocol U.S. Forest Projects." The cited protocols identify field methods employing forest mensuration surveys, model simulation requirements and primary sources, sinks and reservoirs in a series of tables for Reforestation Projects (RF), Improved Forest Management Projects (IFM) and Avoided Conversion Projects (AC). The CARB and CAR forest carbon protocols, while published in separate documents (California Air Resources Board, 2015b; Climate Action Reserve, 2018b) rely on shared estimation protocols for net GHG reductions and removals. For example, both protocols employ forest growth simulation models that use the Forest Vegetation Simulator (FVS) and related vegetation proxies for forest project species. FVS features are coupled with identical numerical equations and carbon pool terms for net forest carbon sequestration directly linking the CARB and CAR protocols (e.g., CARB-CAR) (California Air Resources Board, 2011, 2014, 2015b; Climate Action Reserve, 2018b) (Supplement S6). The underlying models and their specific application to the CARB project location are detailed in documents associated with each of the CARB projects as listed on each CAR project page. Table I provides features of the CARB-CAR data sets that appear to be discretionary and are applied inconsistently across the CARB-CAR project sites. CARB-CAR cites seven approved forest growth and yield models (California Air Resources Board, n.d.); otherwise, shared standards and references are lacking. Details of the ARB Compliance Offset Program and offset credits issued are provided by the CARB website (California Air Resources Board, 2018a). All approved verification protocols must adhere to CARB standards (California Air Resources Board, 2013). The CARB-

Peer] reviewing PDF | (2019:04:36538:2:0:NEW 31 Jul 2019) 
CAR protocol specifies the soil carbon reservoir/pool as item 6 listed as RF-6, IFM- 6 and AC-6. The soil carbon information applicable to the protocols are listed in Tables 5.1 (RF-6), 5.2 (IFM-6) and 5.3 (AC-6) for the protocols published in 2011 (California Air Resources Board, 2014) and 2014 (California Air Resources Board, 2014), respectively. The same information is listed in Tables 4.1 (RF-6), 4.2 (IFM-6) and 4.3 (AC-6) in 2015 (California Air Resources Board, 2015b). Reference to inclusion or exclusion of the soil reservoir for each project listed in Table I is indicated and linked to one of the above protocols as cited in the summary documents provided for each project.

Forest mensuration, or biometric methodology, is intrinsic to the CARB-CAR protocol process and outcomes and is briefly reviewed here. Timber surveys, designed for timber operations, are required every six years or longer (California Air Resources Board, 2014, 2015b), however, simulation models estimate annual incremental change for CARB-CAR net forest carbon sequestration absent annual surveys. CARBCAR Forest mensuration methods rely primarily on measurement of tree diameter at breast height $(\mathrm{DBH})($ Gonçalves et al., 2017). The limitation of the biometric approach is that biomass is not directly measured as it is not quantified by harvest and weight of the carbon pools; this approach is not practical or economically feasible resulting in destruction of the forest. Uncertainties of $50 \%-80 \%$ for individual trees and 20+ \% for plot level estimation persist for forest mensuration (Gonçalves et al., 2017; Holdaway et al., 2014; Paré et al., 2016). Timber survey errors include: 1) variation in the parameters of allometric equation(s) and natural variability of tree structures, 2) measurement errors (DBH, tree height) and differences in frequency of measurement (e.g., multiple measurements per year), and, 3) selection of treespecific parameters within allometric equations such as wood density. The uncertainties are compounded when the forest areas have been or are subject to management including timber extraction, thinning and prescribed or natural fire. In many cases diverse sources of uncertainty are not identified, or new sources of uncertainty are introduced due to bias in data collection, limited coverage of representative forest areas, exclusion of selected carbon pools and inconsistent application of standards and calibration of equipment between measurements. An example of a comprehensive forest mensuration protocol is found in Barford et al. (2001) (e.g., weekly measurement of DBH during the growing season, biomass calculation using density data from a study of northern hardwood forests similar in latitude and elevation, weekly collection of leaf litter during the fall months sorted by genus, dried and weighed. $\mathrm{CO}_{2}$ ecosystem and soil respiration cannot be estimated from forest mensuration methods. Examples of forest mensuration, including soil $\mathrm{CO}_{2}$ and ecosystem respiration efflux, in relation to eddy covariance approaches are well represented (Curtis et al., 2002; Luyssaert et al., 2009; Ouimette et al., 2018).

iv NEE. The NEE1 study reported a mean and standard deviation of approximately $-200.00 \pm 162 \mathrm{gCm}^{-2} \mathrm{yr}^{-1}$ (Baldocchi et al., 2018), compared to a mean of -198.0 and standard deviation of $261.6 \mathrm{gCm}^{-2} \mathrm{yr}^{-1}$ calculated in this study. The difference in mean and standard deviation result from different approaches to calculation. We calculated the sample mean and sample standard deviation of the pooled annual data of 544 points (Supplement S5). The authors of the NEE1 data calculate the mean by first obtaining the 59 means corresponding to the 59 different locations, and then calculating the mean of means (Baldocchi et al., 2018). The NEE1 standard deviation is also based on the deviations of each data point from the corresponding location mean (as opposed to the global mean). The difference in mean and standard deviation noted do not change the conclusions of the summary study (Baldocchi et al., 2018) or our use of that data. Additional data for the Howland Forest (CARB-CAR671, NEE1-Ho1) covering the years 2008 to 2013 that were not included in the NEE1 dataset were obtained from an additional publication (David Hollinger et al., 2016); these values were not included in summary statistics reported. We note that although

Peer] reviewing PDF | (2019:04:36538:2:0:NEW 31 Jul 2019) 
544 site years was reported, four of those site years were absent data; we use the available 540 site year values and identify the four years of missing data in Supplement S5. Data Availability Statement: NEE annual Data cannot be shared publicly because of Fluxnet2015 (https:// fluxnet.fluxdata.org/data/datapolicy/) and Lathuile (https://fluxnet.fluxdata.org/data/la-thuile-dataset/) data policies. However, one can access these data in the same manner as the authors via the Fluxnet2015 dataset (https://fluxnet.fluxdata.org/ data/fluxnet2015-dataset/) and the LaThuile dataset (https://fluxnet.fluxdata.org/data/la-thuile-dataset/). The NEE method is based on direct and fast measurements (e.g., $10 \mathrm{~Hz}$ ) of actual gas transport characterized by a three-dimensional wind field in real time. In this study, we did not control for tower height or upscaling results across the diverse site locations, however, all eddy covariance platforms were positioned above the canopy to capture $\mathrm{CO}_{2}$ flux dynamics. The concentration of the gas of interest (e.g., $\mathrm{CO}_{2},{ }^{13} \mathrm{CO}_{2}$ and ${ }^{14} \mathrm{CO}_{2}$ ) is measured concomitantly resulting in flux of the gas. Flux data are first converted to half-hourly mean grams of carbon per square meter (gC $\left.\mathrm{m}^{-2} \mathrm{~s}^{-1}\right)$ and then summed for each year as the cumulative annual net carbon exchange $\left(\mathrm{gC} \mathrm{m}^{-2} \mathrm{yr}^{-1}\right)$. Tower based estimates of net ecosystem exchange are reported in negative units reflecting a micrometeorological sign convention where flux from the atmosphere is negative, unless otherwise noted. The EC method has been applied worldwide under remote and harsh conditions employing solar power often for months without maintenance (Burba, 2013). Open or closed path gas analyzers (e.g., $\mathrm{CO}_{2}, \mathrm{CH}_{4}, \mathrm{~N}_{2} \mathrm{O}$ ) using shared gas standards coupled with automated flux calculation, telemetry and integrated micrometeorological sensors, for example, are typical and deployed across numerous field platforms readily delivered to the project site. EC data are analyzed by a variety of models across small and large scales to calculate NEE (Burba, 2013). The spatial footprint of the NEE observation scales with height of sampling inlet above the canopy, representing from $\sim 1 \mathrm{~km}^{2}$ to $\sim 10 \mathrm{~km}^{2}$ for typical single EC platforms. Upscaling of EC data provides up to $100 \mathrm{~km}^{2}$ of carbon sequestration data coverage (Kumar et al., 2016; Palmer et al., 2018; Richardson et al., 2012; Stanley et al., 2018). Annual errors in NEE typically range between 30 and $100 \mathrm{gC} \mathrm{m}^{-2} \mathrm{yr}^{-1}$ (Baldocchi, 2008; Burba et al., 2013; Hagen et al., 2006). Gas analyzers for EC measurements are available from a variety of vendors (e.g., Los Gatos Research, San Jose, CA, USA). The CARB-CAR and NEE project locations are diverse across similar biomes, overlapping in one case of the Howland Forest, Maine, USA, (See Supplement S8 for Howland Forest site information).

${ }^{v}$ Carbon markets ideally conserve natural resources (Osborne and Shapiro-Garza, 2018; Warren-Thomas et al., 2018), limit surface warming to $<1.5{ }^{\circ} \mathrm{C}$ relative to the pre-industrial period (IPCC, 2018; Mengis et al., 2018; Rogelj et al., 2018), and are commercially viable (Sandor, Walsh and Marques, 2013; Rogelj et al., 2016; Bryant, 2018). However, uncertainty in carbon product asset value (Dhavale and Sarkis, 2018; Foss, 2018; Dunlop, Winner and Smith, 2019) and market function can negatively affect carbon markets and their efficacy to manage climate change (Helleiner and Thistlethwaite, 2013; Frieling, 2018; Mehling, Metcalf and Stavins, 2018; Zhang, Randhir and Zhang, 2018). For example, global carbon compliance markets have declined from $\sim \$ 95 \mathrm{~B} €$ in 2011 (Thomson Reuters, 2016) to $\$ 41 \mathrm{~B} €$ in 2017 (Thomson Reuters, 2018), a decrease of $\sim 57 \%$, attributed to the absence of a price for carbon (Johannsdottir and McInerney, 2016), oversupply of offsets (Ervine, 2018; Schatzki, Stavins and Hall, 2018), ambiguity of disparate trading platforms (Green, 2017), and as we argue here for forest carbon, absence of direct and verifiable measurement of $\mathrm{CO}_{2}$ and related carbon storage products (Nisbet and Wiess, 2010; Janssens-Maenhout et al., 2011; Peters et al., 2017; Palmer et al., 2018). This uncertainty is reflected in global carbon markets and platforms. Macroeconomic trends for voluntary carbon trading markets are reflected in REDD+ verification programs. For example, 2016 prices for forest carbon were the lowest for REDD+ projects, averaging $\$ 4.60 \mathrm{tCO}_{2} \mathrm{e}$ on the largest volume of all project types (Hammrick \& Gallant, 2017). VCS protocol projects were characterized 
consistently by the lowest pricing of $\$ 4.10 \mathrm{tCO}_{2} \mathrm{e}$ on the largest volume of all standards employed for forest projects (Hammrick \& Gallant, 2017). Transaction volume (millions tons $\mathrm{CO}_{2} \mathrm{e}$ ) for forest carbon offsets fell $\sim 40 \%$ from 2014 to 2016 (Hammrick \& Gallant, 2017). We suggest that the low prices for REDD+ and VCS are, in part, related to the uncertainty and risk of invalidation for net carbon sequestration (Foss, 2018), as demonstrated for Howland Forest. In contrast, CARB-CAR pricing of $\sim \$ 9.70 \mathrm{USD} \mathrm{tCO}_{2} \mathrm{e}$ for 2015 compliance offsets (Hammrick \& Gallant, 2017), emphasize the asymmetry in carbon pricing; similar uncertainties apply to REDD+ (e.g., voluntary) and to CARB-CAR (e.g., compliance) forest carbon offsets. 


\section{Table $\mathbf{1}$ (on next page)}

CARB-CAR site locations, links to online data source and anomalous features

CARB-CAR site locations, links to online data source and anomalous features 


\begin{tabular}{|c|c|c|c|c|c|c|c|c|c|c|c|c|c|c|c|c|}
\hline & $\begin{array}{c}\text { Climat } \\
\text { e } \\
\text { Action } \\
\text { Reserv } \\
\text { e } \#\end{array}$ & $\begin{array}{c}\text { Successo } \\
\mathbf{r} \\
\text { Climate } \\
\text { Action } \\
\text { Reserve } \\
\#\end{array}$ & $\begin{array}{l}\text { AR } \\
\text { B } \\
\text { Proj } \\
\text { ect } \\
\text { ID \# }\end{array}$ & $\begin{array}{l}\text { Project } \\
\text { Name \& } \\
\text { Location }\end{array}$ & $\begin{array}{l}\text { Lo } \\
\text { ng } \\
\text { itu } \\
\text { de }\end{array}$ & $\begin{array}{c}\text { La } \\
\text { tit } \\
\text { u } \\
\text { de }\end{array}$ & $\begin{array}{c}\text { Functional } \\
\text { Type }\end{array}$ & $\begin{array}{l}\text { Ty } \\
\text { pe } \\
\text { of } \\
\text { Pro } \\
\text { toc } \\
\text { ol }\end{array}$ & $\begin{array}{l}\text { A } \\
\text { cr } \\
\text { es } \\
* *\end{array}$ & $\begin{array}{l}\text { He } \\
\text { cta } \\
\text { res }\end{array}$ & $\begin{array}{c}\text { Proje } \\
\text { ct } \\
\text { Inter } \\
\text { val } \\
\text { Vint } \\
\text { age } \\
\text { Years } \\
\text { ) }\end{array}$ & $\begin{array}{c}\text { Projec } \\
t \\
\text { Mana } \\
\text { geme } \\
\text { nt }\end{array}$ & Offsets Issued with Serial Numbers & $\begin{array}{l}\text { Cumulative Performance } \\
\text { Report }\end{array}$ & $\begin{array}{l}\text { Anomalo } \\
\text { us } \\
\text { Features* }\end{array}$ & Soil Carbon Status \\
\hline 1 & $\frac{\underline{\text { CAR1 }}}{\underline{01}}$ & $\mathrm{NA}$ & $\begin{array}{l}\text { CA } \\
\text { FR0 } \\
049\end{array}$ & $\begin{array}{l}\text { The Van } \\
\text { Eck Forest } \\
\text { (Humboldt } \\
\text { County, } \\
\text { CA) }\end{array}$ & $\begin{array}{c}- \\
12 \\
4.0 \\
8\end{array}$ & $\begin{array}{l}40 \\
.8 \\
7\end{array}$ & $\begin{array}{c}\text { Northern } \\
\text { California Coast } \\
\text { (Coast } \\
\text { Redwood/Doug } \\
\text { las Fir Mixed } \\
\text { Conifer) \& } \\
\text { Southern } \\
\text { Cascades } \\
\text { (Southern } \\
\text { Cascade Mixed } \\
\text { Conifer) }\end{array}$ & $\begin{array}{l}\text { Ear } \\
\text { ly } \\
\text { Act } \\
\text { ion }\end{array}$ & $\begin{array}{c}2, \\
10 \\
4\end{array}$ & $\begin{array}{c}85 \\
1\end{array}$ & $\begin{array}{l}2001- \\
2014\end{array}$ & IFM & $\begin{array}{c}\text { https://thereserve2.apx.com/mymodule/r } \\
\text { eg/TabProjectEmissions.asp?id11101\&ad } \\
\text { Prpt\&act=update\&BBtn=\&r=111\&Type }= \\
\text { PRO\&\&ablename=cr\&aProj=pub }\end{array}$ & $\begin{array}{l}\frac{\text { https://thereserve2.apx.co }}{\mathrm{m} / \mathrm{myM} \text { Module/rpt/myrpt. }} \\
\underline{\text { asp?r=802\&md=Prpt\&id1}} \\
=\% \% 20101\end{array}$ & $\begin{array}{l}\wedge \text { ^ (2008) } \\
\text { to 2001; } \\
\# \text { \# (2008) } \\
\text { to } 2014\end{array}$ & $\begin{array}{l}\text { \%\%Reporting Year 2006, } \\
\text { Soil Carbon Pool tCO2e }=0\end{array}$ \\
\hline 2 & $\frac{\underline{\text { CAR1 }}}{\underline{02}}$ & $\begin{array}{c}\text { CAR109 } \\
8\end{array}$ & $\begin{array}{l}\text { CA } \\
\text { FR0 } \\
040\end{array}$ & $\begin{array}{l}\text { Garcia } \\
\text { River } \\
\text { Forest } \\
\text { (Mendocin } \\
\text { o, CA) }\end{array}$ & $\begin{array}{c}12 \\
3.5 \\
1\end{array}$ & $\begin{array}{l}38 \\
.9 \\
1\end{array}$ & $\begin{array}{l}\text { Temperate } \\
\text { coniferous }\end{array}$ & $\begin{array}{l}\text { Ear } \\
\text { ly } \\
\text { Act } \\
\text { ion }\end{array}$ & $\begin{array}{l}23 \\
, 7 \\
80\end{array}$ & $\begin{array}{l}9,6 \\
23\end{array}$ & $\begin{array}{l}2005- \\
2017\end{array}$ & IFM & 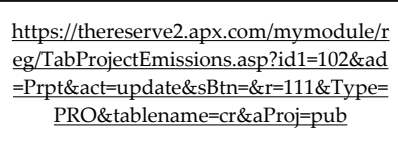 & $\begin{array}{l}\frac{\text { https://thereserve2.apx.co }}{\mathrm{m} / \mathrm{myModule} / \mathrm{rpt} / \mathrm{myrpt}} \\
\underline{\text { asp?r=802\&md=Prpt\&id1}} \\
=\% \text { \%20102 }\end{array}$ & $\begin{array}{l}\wedge \wedge(2007) 2 \\
007-2004 ; \\
\# \#(2007) \\
2008-2014\end{array}$ & $\begin{array}{l}\text { \%\%Reporting Year 2010, } \\
\text { Soil Carbon Pool Excluded } \\
\text { from carbon pool } \\
\text { calculations }\end{array}$ \\
\hline 3 & $\frac{\underline{\text { CAR4 }}}{\underline{08}}$ & $\begin{array}{c}\text { CAR110 } \\
0\end{array}$ & $\begin{array}{l}\text { CA } \\
\text { FR0 } \\
041\end{array}$ & $\begin{array}{l}\text { Big River / } \\
\text { Salmon } \\
\text { Creek } \\
\text { Forests } \\
\text { (Mendocin } \\
\text { o, CA) }\end{array}$ & $\begin{array}{c}12 \\
3.6 \\
7\end{array}$ & $\begin{array}{l}39 \\
.3 \\
01\end{array}$ & $\begin{array}{l}\text { Temperate } \\
\text { coniferous }\end{array}$ & $\begin{array}{l}\text { Ear } \\
\text { ly } \\
\text { Act } \\
\text { ion }\end{array}$ & $\begin{array}{l}15 \\
, 9 \\
11\end{array}$ & $\begin{array}{l}6,4 \\
39\end{array}$ & $\begin{array}{l}2007- \\
2017\end{array}$ & IFM & $\begin{array}{c}\frac{\mathrm{https}: / / \text { thereserve2.apx.com } / \mathrm{myModul} / \mathrm{r}}{\mathrm{pt} / \mathrm{myrptasp} \mathrm{r}=802 \& \mathrm{md} \mathrm{d}=\operatorname{Prpt\& id1}=\% 204} \\
\underline{08}\end{array}$ & $\begin{array}{c}\frac{\mathrm{https}: / / \text { thereserve2.apx.co }}{\mathrm{m} / \mathrm{myM} \text { odule/rpt/myrpt. }} \\
\underline{\text { asp?r=802\&md=Prpt\&\&id1}} \\
\underline{=\% 20408}\end{array}$ & $\begin{array}{l}\# \#(2007) \\
2007- \\
2014 ; \\
\$ 2012\end{array}$ & $\begin{array}{l}\% \% 2007 \text { Project Submittal } \\
\text { Form, Soil Carbon Excluded }\end{array}$ \\
\hline 4 & $\frac{\underline{\text { CAR4 }}}{\underline{29}}$ & NA & $\begin{array}{l}\text { CA } \\
\text { FR0 } \\
073\end{array}$ & $\begin{array}{l}\text { McCloud } \\
\text { River } \\
\text { (McCloud, } \\
\text { CA) }\end{array}$ & $\begin{array}{c}12 \\
2\end{array}$ & $\begin{array}{l}41 \\
.2\end{array}$ & $\begin{array}{l}\text { Temperate } \\
\text { broadleaf and } \\
\text { mixed }\end{array}$ & $\begin{array}{l}\text { Ear } \\
\text { ly } \\
\text { Act } \\
\text { ion }\end{array}$ & $\begin{array}{c}9, \\
20 \\
0\end{array}$ & $\begin{array}{l}3,7 \\
23\end{array}$ & $\begin{array}{l}2006- \\
2014\end{array}$ & IFM & $\begin{array}{c}\text { https://thereserve2.apx.com/mymodule/r } \\
\text { eg/TabProjectEmissions.asp?id11=429\&ad } \\
=\text { Prpt\&act=update\&sBtn=\&r=111\&type= } \\
\text { PRO\&tablename=cr\&aProj=pub }\end{array}$ & $\begin{array}{c}\frac{\underline{\text { https://thereserve2.apx.co }}}{\mathrm{m} / \mathrm{myM} \text { odule/rpt/myrpt. }} \\
\underline{\text { asp?r=802\&md=Prpt\&id1 }} \\
\underline{\underline{=} \% 20429}\end{array}$ & $\begin{array}{l}\# \#(2006) \\
2006 \text { to } \\
2014\end{array}$ & $\begin{array}{l}\% \% 2009 \text { Project Submittal } \\
\text { Form, Soil Carbon N/A }\end{array}$ \\
\hline 5 & $\frac{\underline{\text { CAR4 }}}{\underline{30}}$ & NA & NA & $\begin{array}{c}\text { RPH } \\
\text { Ranch } \\
\text { (Comptche } \\
\text { ' } \\
\text { Mendocino } \\
\text { County, } \\
\text { CA) }\end{array}$ & $\begin{array}{c}12 \\
3.5 \\
9\end{array}$ & $\begin{array}{r}39 \\
.2 \\
6\end{array}$ & $\begin{array}{l}\text { Temperate } \\
\text { coniferous }\end{array}$ & $\begin{array}{l}\text { Ear } \\
\text { ly } \\
\text { Act } \\
\text { ion }\end{array}$ & $\begin{array}{c}10 \\
6\end{array}$ & 43 & 2010 & IFM & $\begin{array}{l}\text { https://thereserve2.apx.com/mymodule/r } \\
\text { eg/TabDocuments.asp?r=11\&ad=Prpt\&a } \\
\frac{\text { ct=update\&type=PRO\&aProj=pub\&table }}{\text { name }=\text { doc\&id1 }=430}\end{array}$ & $\begin{array}{c}\frac{\underline{\text { https://thereserve2.apx.co }}}{\mathrm{m} / \mathrm{myM} \text { odule/rpt/myrpt. }} \\
\frac{\text { asp?r=802\&md=Prpt\&\&1d1}}{\underline{=\% 20430}}\end{array}$ & $\begin{array}{l}\# \#(2002) \\
2002 \text { to } \\
2010 ; \\
\$ \$(00.00) \\
2002 \text { to } \\
2009\end{array}$ & $\begin{array}{l}\% \% 2008 \text { Project Submittal } \\
\text { Form, Soil Carbon N/A }\end{array}$ \\
\hline 6 & $\frac{\text { CAR4 }}{\underline{97}}$ & NA & $\begin{array}{l}\text { CA } \\
\text { FR0 } \\
029\end{array}$ & $\begin{array}{l}\text { Blue } \\
\text { Source- } \\
\text { Alligator } \\
\text { River } \\
\text { (Hyde } \\
\text { County, } \\
\text { NC) }\end{array}$ & $\begin{array}{c}- \\
76 . \\
03 \\
1\end{array}$ & $\begin{array}{l}35 \\
.6 \\
31\end{array}$ & $\begin{array}{l}\text { Northern } \\
\text { Atlantic Coastal } \\
\text { Swamp } \\
\text { Hardwoods, } \\
\text { Cypress }\end{array}$ & $\begin{array}{l}\text { Ear } \\
\text { ly } \\
\text { Act } \\
\text { ion }\end{array}$ & $\begin{array}{l}2 \\
27 \\
2\end{array}$ & $\begin{array}{c}91 \\
9\end{array}$ & $\begin{array}{l}2010- \\
2017\end{array}$ & $\mathrm{AC}$ & $\begin{array}{c}\frac{\text { https://thereserve2.apx.com/mymodule/r }}{\text { eg/TabProjectEmissions.asp?id1=497\&ad }} \\
=\text { Prpt\&act=update\&sBtn=\&r=111\&Type= } \\
\text { PRO\&tablename=cr\&aProj=pub }\end{array}$ & $\begin{array}{l}\frac{\underline{\text { https://thereserve2.apx.co }}}{\frac{\text { m/myModule/rpt/myrpt. }}{\text { asp?r=802\&md }}=\text { Prpt\&id1 }} \\
\underline{\underline{=020497}}\end{array}$ & $\$(2011)$ & $\begin{array}{l}\text { \%\%Project Design } \\
\text { Document, Section } 15 . \\
\text { Carbon Stock Inventory, Soil } \\
\text { Carbon Excluded }\end{array}$ \\
\hline 7 & $\underline{\text { CAR5 }}$ & $\mathrm{NA}$ & $\mathrm{NA}$ & $\begin{array}{c}\text { Arcata } \\
\text { Sunnybrae }\end{array}$ & $\overline{12}$ & $\begin{array}{l}40 \\
.8\end{array}$ & $\begin{array}{c}\text { Northern } \\
\text { California Coast }\end{array}$ & $\begin{array}{c}\text { No } \\
t\end{array}$ & 17 & 69 & 2006- & IFM & $\begin{array}{l}\text { https://thereserve2.apx.com/mymodule/r } \\
\text { eg/TabProjectEmissions.asp?id1=575\&ad }\end{array}$ & $\begin{array}{l}\text { https://thereserve2.apx.co } \\
\text { m/myModule/rpt/myrpt. }\end{array}$ & $\begin{array}{l}\wedge \wedge(2012) \\
2012 \text { to }\end{array}$ & $\begin{array}{l}\text { \%\%Project Design } \\
\text { Document, } 4 \text {. Onsite Carbon }\end{array}$ \\
\hline
\end{tabular}




\begin{tabular}{|c|c|c|c|c|c|c|c|c|c|c|c|c|c|c|c|c|}
\hline & $\underline{75}$ & & & $\begin{array}{l}\text { Tract } \\
\text { (Humbodlt } \\
\text { County, } \\
\text { CA) }\end{array}$ & $\begin{array}{c}4.0 \\
5\end{array}$ & 64 & $\begin{array}{c}\text { (Coast } \\
\text { Redwood/Doug } \\
\text { las Fir Mixed } \\
\text { Conifer) \& } \\
\text { Southern } \\
\text { Cascades } \\
\text { (Southern } \\
\text { Cascade Mixed } \\
\text { Conifer) }\end{array}$ & $\begin{array}{l}\text { Eli } \\
\text { gib } \\
\text { le }\end{array}$ & 1 & & 2015 & & $\frac{=\text { Prpt\&act=update\&sBtn=\&r=111\&Type }=}{\underline{\text { PRO\&tablename }=\text { cr\&aProj=pub }}}$ & $\frac{\underline{\text { asp? } \mathrm{r}=802 \& \mathrm{md}=\text { Prpt\&id } 1}}{\underline{=\% 20575}}$ & $\begin{array}{l}2006 ; \\
\$(2006) \\
\text { one } \\
\text { month }\end{array}$ & Inventory Methodology \\
\hline 8 & $\frac{\frac{\text { CAR5 }}{82}}{\underline{82}}$ & $\begin{array}{c}\text { CAR113 } \\
0\end{array}$ & $\begin{array}{l}\text { CA } \\
\text { FR0 } \\
103\end{array}$ & $\begin{array}{c}\text { Finite } \\
\text { Carbon - } \\
\text { MWF } \\
\text { Brimstone } \\
\text { IFM } \\
\text { Project I } \\
\text { (Scott } \\
\text { County, } \\
\text { TN) }\end{array}$ & $\begin{array}{c}84 . \\
45 \\
5\end{array}$ & $\begin{array}{l}36 \\
.2 \\
72\end{array}$ & Mixed Oak & $\begin{array}{l}\text { Ear } \\
\text { ly } \\
\text { Act } \\
\text { ion }\end{array}$ & $\begin{array}{l}48 \\
61\end{array}$ & $\begin{array}{l}1,9 \\
67\end{array}$ & $\begin{array}{l}2007- \\
2015\end{array}$ & IFM & 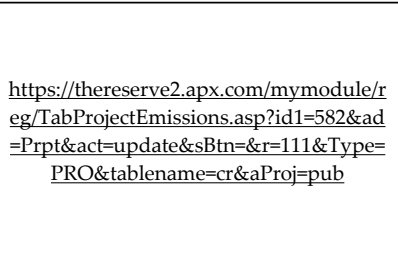 & $\begin{array}{l}\frac{\underline{\text { https://thereserve2.apx.co }}}{\mathrm{m} / \mathrm{myM} \text { odule/rpt/myrpt. }} \\
\frac{\text { asp?r=802\&md=Prpt\&id1 }}{\underline{=\% 20582}}\end{array}$ & 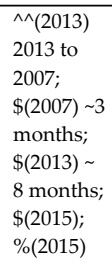 & $\begin{array}{l}\text { \%\%Project Design } \\
\text { Document, Item 23. Soil } \\
\text { Carbon Pool Absent; Table } \\
\text { 23, soil carbon absent, Table } \\
\text { 10, soil carbon absent }\end{array}$ \\
\hline 9 & $\frac{\text { CAR5 }}{\underline{90}}$ & NA & NA & $\begin{array}{l}\text { Lompico } \\
\text { Forest } \\
\text { Carbon } \\
\text { Project } \\
\text { (Santa } \\
\text { Cruz } \\
\text { County, } \\
\text { CA) }\end{array}$ & $\begin{array}{c}- \\
12 \\
2.0 \\
4\end{array}$ & $\begin{array}{l}37 \\
.1 \\
3\end{array}$ & $\begin{array}{l}\text { Temperate } \\
\text { coniferous } \\
\text { Temperate } \\
\text { broadleaf, } \\
\text { mixed } \\
\text { Coastal } \\
\text { Redwood forest }\end{array}$ & $\begin{array}{c}\text { No } \\
t \\
\text { Eli } \\
\text { gib } \\
\text { le }\end{array}$ & $\begin{array}{c}42 \\
5\end{array}$ & $\begin{array}{c}17 \\
2\end{array}$ & $\begin{array}{l}2010- \\
2014\end{array}$ & IFM & $\begin{array}{c}\text { https://thereserve2.apx.com/mymodule/r } \\
\text { eg/TabProjectEmissions.asp?id1=590\&ad } \\
=\frac{\text { Prpt\&act=update\&sBt=\&r=111\&Type }=}{\text { PRO\&tablename=cr\&aProj=pub }}\end{array}$ & $\begin{aligned} \frac{\mathrm{https}: / / \text { thereserve2.apx.co }}{\mathrm{m} / \mathrm{myM} \text { odule/rpt/myrpt. }} \\
\frac{\text { asp?r=802\&md=Prpt\&id1 }}{\underline{=\% 20590}}\end{aligned}$ & $\begin{array}{l}\$ \$(1074.0 \\
0) 2010 \text { to } \\
2012\end{array}$ & $\begin{array}{l}\% \% \text { Project Design } \\
\text { Document, Section 3. Onsite } \\
\text { Carbon Inventory } \\
\text { Methodology, soil carbon } \\
\text { excluded as an optional } \\
\text { carbon pool. }\end{array}$ \\
\hline $\begin{array}{l}1 \\
0\end{array}$ & $\frac{\text { CAR6 }}{\underline{45}}$ & $\begin{array}{c}\text { CAR108 } \\
8\end{array}$ & $\begin{array}{l}\text { CA } \\
\text { FR0 } \\
080\end{array}$ & $\begin{array}{c}\text { Finite } \\
\text { Carbon- } \\
\text { The } \\
\text { Forestland } \\
\text { Group } \\
\text { Champion } \\
\text { Property } \\
\text { (Franklin, } \\
\text { St. } \\
\text { Lawrence } \\
\text { \& Lewis } \\
\text { Counties, } \\
\text { NY) }\end{array}$ & -75 & $\begin{array}{l}44 \\
.3\end{array}$ & $\begin{array}{l}\text { Spruce-fir; Pine } \\
\text { and hemlock; } \\
\text { Northern } \\
\text { hardwoods }\end{array}$ & $\begin{array}{l}\text { Ear } \\
\text { ly } \\
\text { Act } \\
\text { ion }\end{array}$ & $\begin{array}{c}10 \\
0, \\
00 \\
0\end{array}$ & $\begin{array}{c}40 \\
46 \\
9\end{array}$ & $\begin{array}{l}2009- \\
2016\end{array}$ & IFM & $\begin{array}{c}\text { https://thereserve2.apx.com/mymodule/r } \\
\text { eg/TabProjectEmissions.asp?id1=645\&ad } \\
\text { =Prpt\&act=update\&BBtn=\&r=111\&Type }= \\
\text { PRO\&\&tablename=cr\&aProj=pub }\end{array}$ & 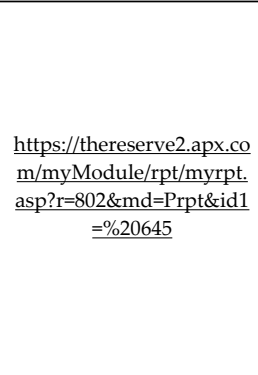 & $\begin{array}{l}\wedge \wedge(2012) \\
2012 \text { to } \\
2009 ; \\
\$(2009) \sim 7 \\
\text { months; } \$ \\
(2014, \\
2015, \\
2016) ; \\
\%(2014, \\
2015, \\
2016 ; \\
\%(2016) \\
2015,2016\end{array}$ & $\begin{array}{l}\% \% \text { Project Design } \\
\text { Document, Table 5. Sources, } \\
\text { Sinks, and Reservoirs, IFM- } \\
\text { 6, Soil Carbon excluded }\end{array}$ \\
\hline $\begin{array}{l}1 \\
1\end{array}$ & $\frac{\text { CAR6 }}{\underline{46}}$ & NA & NA & $\begin{array}{l}\text { Katahdin } \\
\text { Iron Works } \\
\text { Ecological } \\
\text { Reserve } \\
\text { (Piscataqui } \\
\text { s County, } \\
\text { ME) }\end{array}$ & $\begin{array}{c}- \\
69 . \\
17\end{array}$ & $\begin{array}{l}45 \\
.4 \\
5\end{array}$ & $\begin{array}{c}\text { Evergreen } \\
\text { Needleleaf } \\
\text { Forest }\end{array}$ & $\begin{array}{c}\text { No } \\
t \\
\text { Eli } \\
\text { gib } \\
\text { le }\end{array}$ & $\begin{array}{l}10 \\
, 0 \\
00\end{array}$ & $\begin{array}{l}4,0 \\
47\end{array}$ & $\begin{array}{l}2007- \\
2012\end{array}$ & IFM & $\begin{aligned} \frac{h \text { htps://thereserve2.apx.com/mymodule/r }}{\text { eg/TabProjectEmissions.asp?r=111\&ad=P }} \\
\text { rpt\&act=update\&type=PRO\&aProj=pub\& } \\
\text { tablename=cr\&id1=646 }\end{aligned}$ & $\begin{array}{l}\frac{\underline{\text { https://thereserve2.apx.co }}}{\text { m/myModule/rpt/myrpt. }} \\
\frac{\underline{\text { asp?r=802\&md=Prpt\&id1 }}}{\underline{=\% 20646}}\end{array}$ & $\begin{array}{l}\$(2007) \sim 8 \\
\text { months; } \\
\wedge \wedge(2013) \\
2013 \text { to } \\
2007\end{array}$ & $\begin{array}{l}\text { \%\%Project Design } \\
\text { Document, Section } 3 . \\
\text { Inventory Methodology, } \\
\text { IFM-4, Soil Carbon excluded }\end{array}$ \\
\hline $\begin{array}{l}1 \\
2\end{array}$ & $\frac{\underline{\text { CAR } 6}}{\underline{48}}$ & $\begin{array}{l}\text { CAR108 } \\
6\end{array}$ & $\begin{array}{l}\text { CA } \\
\text { FR0 } \\
047\end{array}$ & $\begin{array}{c}\text { Finite } \\
\text { Carbon- } \\
\text { Potlatch } \\
\text { Moro Big } \\
\text { Pine CE } \\
\text { (Calhoun } \\
\end{array}$ & $\begin{array}{c}- \\
92 . \\
54\end{array}$ & $\begin{array}{c}33 \\
.5\end{array}$ & $\begin{array}{c}\text { Evergreen } \\
\text { Needleleaf } \\
\text { Forest }\end{array}$ & $\begin{array}{l}\text { Ear } \\
\text { ly } \\
\text { Act } \\
\text { ion }\end{array}$ & $\begin{array}{c}16 \\
, 0 \\
00\end{array}$ & $\begin{array}{l}6,4 \\
75\end{array}$ & $\begin{array}{l}2006- \\
2014\end{array}$ & IFM & $\begin{array}{c}\text { https://thereserve2.apx.com/mymodule/r } \\
\text { eg/TabProjectEmissions.asp?id1=648\&ad } \\
\text { =Prpt\&act=update\&BBtn=\&r=111\&Type= } \\
\text { PRO\&\&tablename=cr\&aProj=pub }\end{array}$ & $\begin{array}{l}\frac{\underline{\text { https://thereserve2.apx.co }}}{\text { m/myModule/rpt/myrpt. }} \\
\underline{\text { asp?r=802\&md=Prpt\&id1 }} \\
\underline{=\% 20648}\end{array}$ & $\begin{array}{l}\$(2006) \sim 1 \\
\text { month; } \\
\wedge \wedge(2013) \\
2013 \text { to } \\
2006 ; \\
\$(2013) \sim 7 \\
\end{array}$ & $\begin{array}{l}\% \% \text { Project t Design } \\
\text { Document, Table 7. Sources, } \\
\text { Sinks, and Reservoirs, IFM- } \\
\text { 6, soil carbon excluded. }\end{array}$ \\
\hline
\end{tabular}




\begin{tabular}{|c|c|c|c|c|c|c|c|c|c|c|c|c|c|c|c|c|}
\hline & & & & $\begin{array}{l}\text { County, } \\
\text { AR) }\end{array}$ & & & & & & & & & & & $\begin{array}{l}\text { months; } \\
\% \text { (2014) } \\
2012, \\
2013, \\
2014 ; \\
\$(2014) \sim 7 \\
\text { months }\end{array}$ & \\
\hline $\begin{array}{l}1 \\
3\end{array}$ & $\frac{\text { CAR6 }}{\underline{55}}$ & $\mathrm{NA}$ & $\begin{array}{l}\text { CA } \\
\text { FR0 } \\
105\end{array}$ & $\begin{array}{c}\text { Alder } \\
\text { Stream } \\
\text { Preserve } \\
\text { (Piscataqui } \\
\text { s County, } \\
\text { ME) }\end{array}$ & $\begin{array}{c}- \\
69 . \\
01 \\
5\end{array}$ & $\begin{array}{l}45 \\
.1 \\
14\end{array}$ & $\begin{array}{c}\text { Evergreen } \\
\text { Needleleaf } \\
\text { Forest }\end{array}$ & $\begin{array}{l}\text { Ear } \\
\text { ly } \\
\text { Act } \\
\text { ion }\end{array}$ & $\begin{array}{c}1 \\
46 \\
0\end{array}$ & $\begin{array}{c}59 \\
1\end{array}$ & $\begin{array}{l}2006- \\
2013\end{array}$ & IFM & 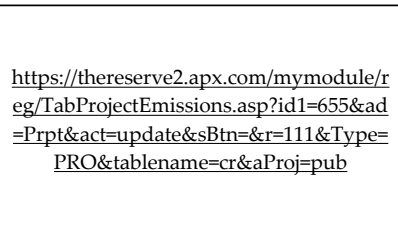 & 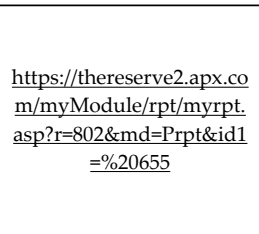 & $\begin{array}{l}\$ \text { initial } \\
\text { year } 1 \\
\text { month, } \\
2006 ; \# \text {; } \\
2012, \\
2014 ; \\
\# 2006 \text { to } \\
2013\end{array}$ & $\begin{array}{l}\text { \%\%Project Design } \\
\text { Document, Section 3, } \\
\text { Inventory Methodology, } \\
\text { IFM-6, soil carbon excluded }\end{array}$ \\
\hline $\begin{array}{l}1 \\
4\end{array}$ & $\frac{\text { CAR6 }}{\underline{57}}$ & $\begin{array}{c}\text { CAR106 } \\
3\end{array}$ & $\begin{array}{l}\text { CA } \\
\text { FR0 } \\
002\end{array}$ & $\begin{array}{c}\text { Finite } \\
\text { Carbon } \\
\text { Farm Cove } \\
\text { Communit } \\
\text { y Forest } \\
\text { Project } \\
\text { (Near } \\
\text { Grand } \\
\text { Lake } \\
\text { Stream, } \\
\text { Maine) }\end{array}$ & $\begin{array}{c}- \\
67 . \\
85 \\
1\end{array}$ & $\begin{array}{l}45 \\
.1 \\
87\end{array}$ & $\begin{array}{c}\text { Evergreen } \\
\text { Needleleaf } \\
\text { Forest }\end{array}$ & $\begin{array}{l}\text { Ear } \\
\text { ly } \\
\text { Act } \\
\text { ion }\end{array}$ & $\begin{array}{l}19 \\
7 \\
69\end{array}$ & $\begin{array}{l}8,0 \\
00\end{array}$ & $\begin{array}{r}2010- \\
2015\end{array}$ & IFM & $\begin{array}{c}\text { https://thereserve2.apx.com/mymodule/r } \\
\text { eg/TabProjectEmissions.asp?id1=657\&ad } \\
\text { Prpt\&act=update\&sBtn=\&r=111\&Type }= \\
\text { PRO\&\&ablename=cr\&aProj=pub }\end{array}$ & 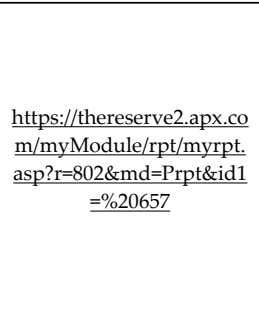 & $\begin{array}{l}\$(2003)< \\
1 \text { month; } \\
\wedge \wedge(2012) \\
2011 \text { to } \\
2003\end{array}$ & $\begin{array}{l}\% \% \text { Project Design } \\
\text { Document, Section A13. } \\
\text { Carbon Pools,. IFM-6, soil } \\
\text { carbon excluded }\end{array}$ \\
\hline $\begin{array}{l}1 \\
5\end{array}$ & $\frac{\text { CAR6 }}{\underline{58}}$ & $\begin{array}{c}\text { CAR113 } \\
4\end{array}$ & $\begin{array}{l}\text { CA } \\
\text { FR0 } \\
087\end{array}$ & $\begin{array}{c}\text { Finite } \\
\text { Carbon- } \\
\text { Brosnan } \\
\text { Forest } \\
\text { (Near } \\
\text { Charleston } \\
\text {,SC) }\end{array}$ & $\begin{array}{c}- \\
80 . \\
45\end{array}$ & $\begin{array}{l}33 \\
.1 \\
67\end{array}$ & $\begin{array}{c}\text { Evergreen } \\
\text { Needleleaf } \\
\text { Forest }\end{array}$ & $\begin{array}{l}\text { Ear } \\
\text { ly } \\
\text { Act } \\
\text { ion }\end{array}$ & $\begin{array}{l}10 \\
, 2 \\
09\end{array}$ & $\begin{array}{l}4,1 \\
31\end{array}$ & $\begin{array}{l}2010- \\
2011 ; \\
2015- \\
2016\end{array}$ & IFM & $\begin{array}{c}\text { https://thereserve2.apx.com/mymodule/r } \\
\text { eg/TabProjectEmissions.asp?id1=658\&ad } \\
=\text { Prpt\&act=update\&sBtn=\&r=111\&Type }= \\
\underline{\text { PRO\&tablename=cr\&aProj=pub }}\end{array}$ & $\begin{array}{c}\frac{\underline{\text { https://thereserve2.apx.co }}}{\mathrm{m} / \mathrm{myM} \text { odule/rpt/myrpt. }} \\
\frac{\text { asp?r=802\&md=Prpt\&\&1d1 }}{\underline{=\% 20658}}\end{array}$ & $\begin{array}{l}\#(2010) \\
\$(2013) \sim 8 \\
\text { months; } \\
\wedge \wedge(2013) \\
2011 \text { to } \\
2010\end{array}$ & $\begin{array}{l}\text { \%\%Project Design } \\
\text { Document, Section A13. } \\
\text { Carbon Pools,. IFM-6, soil } \\
\text { carbon excluded }\end{array}$ \\
\hline $\begin{array}{l}1 \\
6\end{array}$ & $\frac{\text { CAR6 }}{\underline{59}}$ & $\mathrm{NA}$ & $\begin{array}{l}\text { CA } \\
\text { FR0 } \\
026\end{array}$ & $\begin{array}{c}\text { Blue } \\
\text { Source- } \\
\text { Pungo } \\
\text { River } \\
\text { Forest } \\
\text { Conservati } \\
\text { on Project } \\
\text { (Washingt } \\
\text { on County, } \\
\text { NC) }\end{array}$ & $\begin{array}{c}- \\
76 . \\
64\end{array}$ & $\begin{array}{l}35 \\
.8 \\
04\end{array}$ & $\begin{array}{l}\text { Atlantic Coastal } \\
\text { Plain -- } \\
\text { Swamp } \\
\text { Hardwood } \\
\text { and Cypress }\end{array}$ & $\begin{array}{l}\text { Ear } \\
\text { ly } \\
\text { Act } \\
\text { ion }\end{array}$ & $\begin{array}{c}70 \\
4\end{array}$ & $\begin{array}{c}28 \\
5\end{array}$ & $\begin{array}{c}2003- \\
2016\end{array}$ & AC & 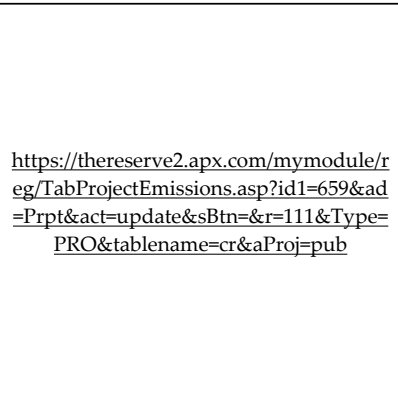 & $\begin{aligned} \frac{\underline{\text { https://thereserve2.apx.co }}}{\mathrm{m} / \mathrm{myM} \text { odule/rpt/myrpt. }} \\
\frac{\underline{\text { asp?r}=802 \& \mathrm{md}=\text { Prpt\&id1 }}}{\underline{=\% 20659}}\end{aligned}$ & 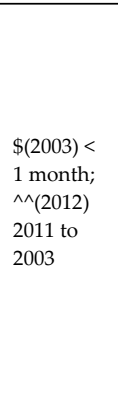 & $\begin{array}{l}\text { \%\%Project Design } \\
\text { Document, 11.2.3.4.1 Soil } \\
\text { carbon was sampled to } \\
\text { establish starting carbon } \\
\text { stocks } \\
\text { that would be degraded if } \\
\text { the baseline } \\
\text { scenario was followed, e.g. } \\
\text { full conversion to } \\
\text { agricultural use. The soil } \\
\text { carbon was excluded as } \\
\text { source of CO2 over the } \\
\text { lifetime of the project (e.g., } \\
\text { AC-6). }\end{array}$ \\
\hline $\begin{array}{l}1 \\
7\end{array}$ & $\frac{\text { CAR6 }}{\underline{60}}$ & $\begin{array}{c}\text { CAR109 } \\
9\end{array}$ & $\begin{array}{l}\text { CA } \\
\text { FR0 } \\
042\end{array}$ & $\begin{array}{l}\text { Gualala } \\
\text { River } \\
\text { Forest } \\
\text { (Southern } \\
\text { Mendocino }\end{array}$ & $\begin{array}{c}- \\
12 \\
3.4 \\
02\end{array}$ & $\begin{array}{l}38 \\
.7 \\
96\end{array}$ & $\begin{array}{c}\text { Coastal } \\
\text { Redwood and } \\
\text { Douglas Fir }\end{array}$ & $\begin{array}{l}\text { Ear } \\
\text { ly } \\
\text { Act } \\
\text { ion }\end{array}$ & $\begin{array}{l}13 \\
, 9 \\
13\end{array}$ & $\begin{array}{l}5,6 \\
30\end{array}$ & $\begin{array}{l}2004- \\
2017\end{array}$ & IFM & $\begin{array}{l}\text { https://thereserve2.apx.com/mymodule/r } \\
\text { eg/TabProjectEmissions.asp?id1=660\&ad } \\
=\text { Prpt\&act=update\&sBtn=\&r=111\&Type }= \\
\text { PRO\&tablename=cr\&aProj=pub }\end{array}$ & $\begin{array}{l}\frac{\underline{\mathrm{https}: / \text { thereserve2.apx.co }}}{\underline{\mathrm{m} / \mathrm{myModule} / \mathrm{rpt} / \mathrm{myrpt}}} \\
\underline{\text { asp?r}=802 \& \mathrm{md}=\text { Prpt\&id1 }} \\
\underline{\equiv} \% 20660\end{array}$ & $\begin{array}{l}\wedge^{\wedge}(2011) \\
2010 \text { to } \\
2004 ; \\
\%(2015) \\
2015\end{array}$ & $\begin{array}{l}\text { \%\%Project Design } \\
\text { Document, Section } 7 . \\
\text { Summary of the carbon } \\
\text { stock inventory for the } \\
\text { Forest Project by }\end{array}$ \\
\hline
\end{tabular}




\begin{tabular}{|c|c|c|c|c|c|c|c|c|c|c|c|c|c|c|c|c|}
\hline & & & & $\begin{array}{l}\text { County, } \\
\text { Near } \\
\text { Gualala, } \\
\text { CA) }\end{array}$ & & & & & & & & & & & $\begin{array}{l}\text { 2016; } \\
\%(2017) \\
2016,2017\end{array}$ & $\begin{array}{l}\text { each pool, soil carbon pool } \\
\text { excluded }\end{array}$ \\
\hline $\begin{array}{l}1 \\
8\end{array}$ & $\frac{\underline{\text { CAR6 }}}{\underline{61}}$ & $\begin{array}{c}\text { CAR114 } \\
0\end{array}$ & $\begin{array}{l}\text { CA } \\
\text { FR0 } \\
001\end{array}$ & $\begin{array}{l}\text { Willits } \\
\text { Woods } \\
\text { (Near } \\
\text { Willitis, } \\
\text { CA) }\end{array}$ & $\begin{array}{l}12 \\
3.3 \\
57\end{array}$ & $\begin{array}{l}39 \\
.4 \\
11\end{array}$ & $\begin{array}{c}\text { Coastal } \\
\text { Redwood and } \\
\text { Douglas Fir }\end{array}$ & $\begin{array}{l}\text { Ear } \\
\text { ly } \\
\text { Act } \\
\text { ion }\end{array}$ & $\begin{array}{l}18 \\
, 0 \\
08\end{array}$ & $\begin{array}{l}7,2 \\
88\end{array}$ & $\begin{array}{l}2004- \\
2016\end{array}$ & IFM & 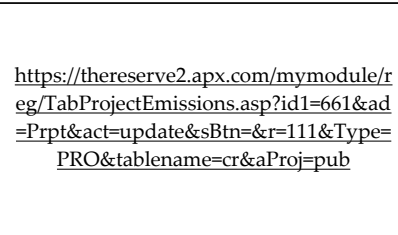 & $\begin{aligned} \frac{\mathrm{https}: / / \text { thereserve2.apx.co }}{\mathrm{m} / \mathrm{myM} \text { Module/rpt/myrpt. }} \\
\frac{\underline{\text { asp?r}=802 \& \mathrm{md}=\operatorname{Prpt} \& \mathrm{id} 1}}{\underline{=\% 20661}}\end{aligned}$ & $\begin{array}{l}\wedge \wedge(2011) \\
2010 \text { to } \\
2004\end{array}$ & $\begin{array}{l}\text { \%\%Project Design } \\
\text { Document, Section } 5 . \\
\text { Calculation methodologies } \\
\text { for determining metric tones } \\
\text { per } \\
\text { acre for each of the included } \\
\text { carbon pools, soil carbon } \\
\text { excluded }\end{array}$ \\
\hline $\begin{array}{l}1 \\
9\end{array}$ & $\frac{\mathrm{CAR} 6}{\underline{72}}$ & NA & $\begin{array}{l}\text { CA } \\
\text { FR0 } \\
116\end{array}$ & $\begin{array}{l}\text { Hershey } \\
\text { Mountain } \\
\text { (North of } \\
\text { Concord, } \\
\text { NH) }\end{array}$ & $\begin{array}{c}- \\
71 . \\
66 \\
7\end{array}$ & $\begin{array}{l}43 \\
.5 \\
67\end{array}$ & $\begin{array}{l}\text { Adirondacks \& } \\
\text { Green } \\
\text { Mountains } \\
\text { Northern } \\
\text { Hardwood }\end{array}$ & $\begin{array}{l}\text { Ear } \\
\text { ly } \\
\text { Act } \\
\text { ion }\end{array}$ & $\begin{array}{c}2, \\
14 \\
1\end{array}$ & $\begin{array}{c}86 \\
6\end{array}$ & $\begin{array}{l}2007- \\
2013\end{array}$ & IFM & 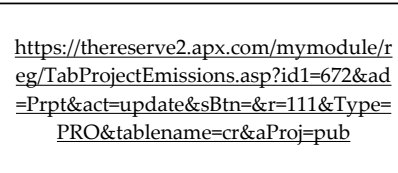 & $\begin{aligned} \frac{\mathrm{https}: / / \text { thereserve2.apx.co }}{\mathrm{m} / \mathrm{myM} M \text { odule/rpt/myrpt. }} \\
\frac{\underline{\text { asp?r}=802 \& \mathrm{md}=\text { Prpt\&id1 }}}{\underline{=\% 20672}}\end{aligned}$ & $\begin{array}{l}\#(2007) ; \\
\$(2007) \sim 6 \\
\text { months; } \\
\wedge \wedge(2014) \\
2013 \text { to } \\
2007\end{array}$ & $\begin{array}{l}\text { \%\%Project Design } \\
\text { Document, Section A13. } \\
\text { Carbon Pools, soil carbon } \\
\text { FM-6 excluded }\end{array}$ \\
\hline $\begin{array}{l}2 \\
0\end{array}$ & $\frac{\text { CAR6 }}{\underline{76}}$ & NA & $\begin{array}{l}\text { CA } \\
\text { FR0 } \\
031\end{array}$ & $\begin{array}{c}\text { Pocosin } \\
\text { Lakes } \\
\text { Forest } \\
\text { Conservati } \\
\text { on Project } \\
\text { (Tyrrell } \\
\text { County, } \\
\text { NC) }\end{array}$ & $\begin{array}{c}76 . \\
20 \\
9\end{array}$ & $\begin{array}{l}35 \\
.8 \\
62\end{array}$ & $\begin{array}{l}\text { Atlantic Coastal } \\
\text { Plain, Swamp } \\
\text { Hardwood and } \\
\text { Cypress }\end{array}$ & $\begin{array}{l}\text { Ear } \\
\text { ly } \\
\text { Act } \\
\text { ion }\end{array}$ & $\begin{array}{c}1 \\
34 \\
9\end{array}$ & $\begin{array}{c}54 \\
6\end{array}$ & $\begin{array}{r}2003- \\
2012\end{array}$ & AC & $\begin{array}{c}\text { https://thereserve2.apx.com/mymodule/r } \\
\text { eg/TabProjectEmissions.asp?id1=676\&ad } \\
=\text { Prpt\&act=update\&sBtn=\&r=11\&Type }= \\
\text { PRO\&tablename=cr\&aProj=pub }\end{array}$ & $\begin{array}{c}\frac{\underline{\text { https://thereserve2.apx.co }}}{\text { m/myModule/rpt/myrpt. }} \\
\underline{\underline{\text { asp?r=802\&md=Prpt\&id1 }}} \\
\underline{=\% 20676}\end{array}$ & $\begin{array}{l}\wedge \wedge(2012) \\
2011 \text { to } \\
2003 ; \\
\$(2003) \sim 2 \\
\text { months; }\end{array}$ & $\begin{array}{l}\text { \%\%Project Design } \\
\text { Document, 11.2.3.4.1 Soil } \\
\text { carbon was sampled to } \\
\text { establish starting carbon } \\
\text { stocks } \\
\text { that would be degraded if } \\
\text { the baseline } \\
\text { scenario was followed, e.g. } \\
\text { full conversion to } \\
\text { agricultural use. The soil } \\
\text { carbon was excluded as } \\
\text { source of CO2 over the } \\
\text { lifetime of the project (e.g." } \\
\text { AC-6 }\end{array}$ \\
\hline $\begin{array}{l}2 \\
1\end{array}$ & $\frac{\underline{\mathrm{CAR}} 6}{\underline{81}}$ & NA & $\begin{array}{l}\text { CA } \\
\text { FR0 } \\
106\end{array}$ & $\begin{array}{l}\text { Howland } \\
\text { Research } \\
\text { Forest } \\
\text { (Howland, } \\
\text { ME) }\end{array}$ & $\begin{array}{c}- \\
68 . \\
62 \\
7\end{array}$ & $\begin{array}{l}45 \\
.2 \\
46\end{array}$ & $\begin{array}{l}\text { Red Spruce and } \\
\text { Eastern } \\
\text { Hemlock }\end{array}$ & $\begin{array}{l}\text { Ear } \\
\text { ly } \\
\text { Act } \\
\text { ion }\end{array}$ & $\begin{array}{c}55 \\
2\end{array}$ & $\begin{array}{c}22 \\
3\end{array}$ & $\begin{array}{r}2008- \\
2013\end{array}$ & IFM & $\begin{array}{c}\text { https://thereserve2.apx.com/mymodule/r } \\
\text { eg/TabProjectEmissions.asp?id1=681\&ad } \\
=\text { Prpt\&act=update\&sBtn=\&r=111\&Type= } \\
\text { PRO\&tablename=cr\&aProj=pub }\end{array}$ & $\begin{array}{c}\frac{\underline{\text { https://thereserve2.apx.co }}}{\mathrm{m} / \mathrm{myM} \text { Module/rpt/myrpt. }} \\
\frac{\text { asp?r=802\&md=Prpt\&id1 }}{\underline{=\% 20681}}\end{array}$ & $\begin{array}{l}\#(2008) ; \\
\$(2008) ; \\
\wedge \wedge(2014) \\
2013 \text { to } \\
2008 ; \\
\%(2008) \\
2008,2008\end{array}$ & $\begin{array}{l}\% \% \text { Project Design } \\
\text { Document, Section } 3 \\
\text { Inventory Methodology, } \\
\text { IFM-6, soil carbon excluded }\end{array}$ \\
\hline $\begin{array}{l}2 \\
2\end{array}$ & $\frac{\mathrm{CAR} 6}{\underline{83}}$ & NA & $\begin{array}{l}\text { CA } \\
\text { FR0 } \\
030\end{array}$ & $\begin{array}{c}\text { Francis } \\
\text { Beidler } \\
\text { Project } \\
\text { (Berkeley, } \\
\text { Dorchester } \\
\text { and } \\
\text { Orangebur } \\
\text { g Counties, } \\
\text { SC) }\end{array}$ & $\begin{array}{c}- \\
80 . \\
35 \\
8\end{array}$ & $\begin{array}{l}33 \\
.3 \\
21\end{array}$ & $\begin{array}{l}\text { Native } \\
\text { Hardwoods, } \\
\text { Softwoods, } \\
\text { Mixed Forest }\end{array}$ & $\begin{array}{l}\text { Ear } \\
\text { ly } \\
\text { Act } \\
\text { ion }\end{array}$ & $\begin{array}{c}5, \\
54 \\
8\end{array}$ & $\begin{array}{l}2,2 \\
45\end{array}$ & $\begin{array}{l}2007- \\
2017\end{array}$ & IFM & $\begin{array}{c}\text { https://thereserve2.apx.com/mymodule/r } \\
\text { eg/TabProjectEmissions.asp?id1=683\&ad } \\
=\text { Prpt\&act=update\&sBtn=\&r=11\&Type= } \\
\text { PRO\&tablename=cr\&aProj=pub }\end{array}$ & $\begin{array}{l}\frac{\underline{\text { https://thereserve2.apx.co }}}{\mathrm{m} / \mathrm{myModule} / \mathrm{rpt} / \mathrm{myrpt} .} \\
\frac{\text { asp?r=802\&md=Prpt\&id1 }}{\underline{\equiv 20683}}\end{array}$ & $\begin{array}{l}\#(2007) \sim 5 \\
\text { months; } \\
\$(2012) ; \\
\wedge \wedge(2012) \\
2012 \text { to } \\
2007 ; \\
\wedge \wedge(2015) \\
2015 \text { to } \\
2012 ; \\
\$(2015) ; \\
\$(2016) ; \\
\$(2017)\end{array}$ & $\begin{array}{l}\% \% \text { Project Design } \\
\text { Document, Section 3, } \\
\text { Inventory Methodology, soil } \\
\text { carbon excluded }\end{array}$ \\
\hline
\end{tabular}




\begin{tabular}{|c|c|c|c|c|c|c|c|c|c|c|c|c|c|c|c|c|}
\hline $\begin{array}{l}2 \\
3\end{array}$ & $\frac{\underline{\text { CAR6 }}}{\underline{86}}$ & $\begin{array}{c}\text { CAR116 } \\
0\end{array}$ & $\begin{array}{l}\text { CA } \\
\text { FR0 } \\
058\end{array}$ & $\begin{array}{c}\text { Virginia } \\
\text { Conservati } \\
\text { on Forestry } \\
\text { Program - } \\
\text { Clifton } \\
\text { Farm } \\
\text { (Near } \\
\text { Rosedale, } \\
\text { VA) }\end{array}$ & $\begin{array}{c}- \\
81 . \\
86\end{array}$ & $\begin{array}{l}37 \\
.0 \\
22\end{array}$ & $\begin{array}{l}\text { Mixed Pine } \\
\text { Hardwood, } \\
\text { Cove Forests, } \\
\text { Oak - Hickory }\end{array}$ & $\begin{array}{l}\text { Ear } \\
\text { ly } \\
\text { Act } \\
\text { ion }\end{array}$ & $\begin{array}{c}4, \\
06 \\
9\end{array}$ & $\begin{array}{l}1,6 \\
47\end{array}$ & $\begin{array}{l}2004- \\
2016\end{array}$ & IFM & 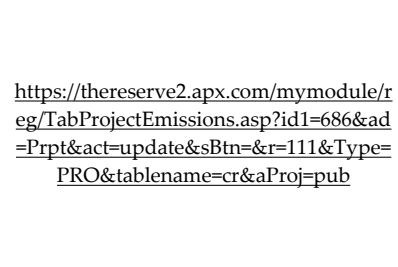 & $\begin{array}{l}\frac{\underline{\text { https://thereserve2.apx.co }}}{\mathrm{m} / \mathrm{myM} \text { Module/rpt/myrpt. }} \\
\frac{\underline{\text { asp?r=802\&md=Prpt\&id1 }}}{\underline{=\% 20686}}\end{array}$ & $\begin{array}{l}\wedge \wedge(2012) \\
2011 \text { to } \\
20014 ; \\
\wedge(2014) \\
2013 \text { to } \\
2012) ; \\
\$(2016) \\
2015,2016\end{array}$ & $\begin{array}{l}\% \% \text { Project Submittal Form, } \\
\text { Item } 10, \text { soil carbon } \\
\text { excluded }\end{array}$ \\
\hline $\begin{array}{l}2 \\
4\end{array}$ & $\frac{\underline{\text { CAR6 }}}{\underline{88}}$ & NA & $\begin{array}{l}\text { CA } \\
\text { FR0 } \\
028\end{array}$ & $\begin{array}{c}\text { Blue } \\
\text { Source- } \\
\text { Noles } \\
\text { North } \\
\text { Forest } \\
\text { Project } \\
\text { (Washingt } \\
\text { on and } \\
\text { Hyde } \\
\text { Counties, } \\
\text { NC) }\end{array}$ & $\begin{array}{c}76 . \\
54 \\
8\end{array}$ & $\begin{array}{l}35 \\
.8 \\
81\end{array}$ & $\begin{array}{l}\text { Atlantic Coastal } \\
\text { Plain, } \\
\text { Swamp } \\
\text { Hardwood and } \\
\text { Cypress }\end{array}$ & $\begin{array}{l}\text { Ear } \\
\text { ly } \\
\text { Act } \\
\text { ion }\end{array}$ & $\begin{array}{c}28 \\
1\end{array}$ & $\begin{array}{c}11 \\
4\end{array}$ & $\begin{array}{l}2002- \\
2016\end{array}$ & AC & $\begin{array}{c}\text { https://thereserve2.apx.com/mymodule/r } \\
\text { eg/TabProjectEmissions.asp?id1=688\&\&ad } \\
=\text { Prpt\&act=update\&sBtn=\&r=11\&Type= } \\
\text { PRO\&tablename=cr\&aProj=pub }\end{array}$ & $\begin{array}{c}\frac{\underline{\text { https://thereserve2.apx.co }}}{\mathrm{m} / \mathrm{myM} \text { Module/rpt/myrpt. }} \\
\underline{\text { asp?r=802\&md=Prpt\&id1 }} \\
\underline{=\% 20688}\end{array}$ & $\begin{array}{l}\$(2002) \sim 7 \\
\text { months; } \\
\wedge \wedge(2012) \\
2011 \text { to } \\
2002 ; \\
\$(6,099.0 \\
0) 2003 \text { to } \\
2009 ; \\
\$(5,830.0 \\
\text { 0) 2013 to } \\
2014\end{array}$ & $\begin{array}{l}\text { \%\%Project Design } \\
\text { Document, 11.2.3.4.1 Soil } \\
\text { carbon was sampled to } \\
\text { establish starting carbon } \\
\text { stocks } \\
\text { that would be degraded if } \\
\text { the baseline } \\
\text { scenario was followed, e.g. } \\
\text { full conversion to } \\
\text { agricultural use. The soil } \\
\text { carbon was excluded as } \\
\text { source of CO2 over the } \\
\text { lifetime of the project (e.g., } \\
\text { AC-6) }\end{array}$ \\
\hline $\begin{array}{l}2 \\
5\end{array}$ & $\frac{\text { CAR6 }}{\underline{94}}$ & NA & NA & $\begin{array}{l}\text { Lucchesi } \\
\text { Tract } \\
\text { (Humboldt } \\
\text { County, } \\
\text { CA) }\end{array}$ & $\begin{array}{l}- \\
12 \\
4.0 \\
64\end{array}$ & $\begin{array}{l}40 \\
.8 \\
75\end{array}$ & $\begin{array}{l}\text { Temperate } \\
\text { coniferous, } \\
\text { Temperate } \\
\text { rainforest; }\end{array}$ & $\begin{array}{c}\text { No } \\
t \\
\text { Eli } \\
\text { gib } \\
\text { le }\end{array}$ & $\begin{array}{c}32 \\
2\end{array}$ & $\begin{array}{c}13 \\
0\end{array}$ & $\begin{array}{l}2010- \\
2016\end{array}$ & IFM & 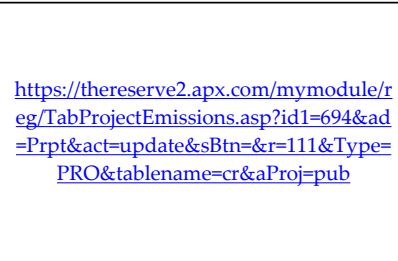 & 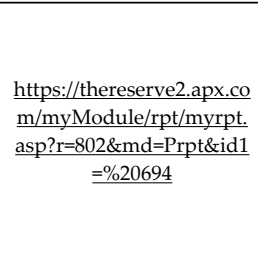 & $\begin{array}{l}\wedge \wedge(2012) \\
2011 \text { to } \\
2001 ; \\
\$ \$(00.00) 2 \\
001 \text { to } \\
2009 ; \\
\$ \$(2,182.0 \\
0) 2012 \text { to } \\
2016\end{array}$ & $\begin{array}{l}\text { \%\%Project Design } \\
\text { Document, Section D. Step } \\
4 \text {. Determine the baseline } \\
\text { carbon stocks over } 100 \text { years } \\
\text { for all required and optiona } \\
\text { carbon } \\
\text { pools in the Project Area, } \\
\text { soil carbon excluded }\end{array}$ \\
\hline $\begin{array}{l}2 \\
6\end{array}$ & $\frac{\text { CAR6 }}{\underline{96}}$ & $\begin{array}{c}\text { CAR115 } \\
9\end{array}$ & $\begin{array}{l}\text { CA } \\
\text { FR0 } \\
057\end{array}$ & $\begin{array}{c}\text { Rich } \\
\text { Mountain } \\
\text { (Russell \& } \\
\text { Washingto } \\
\text { n Counties, } \\
\text { NW of } \\
\text { Saltville, } \\
\text { VA) }\end{array}$ & $\begin{array}{l}82 . \\
03\end{array}$ & $\begin{array}{l}36 \\
.8 \\
31\end{array}$ & 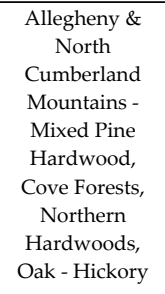 & $\begin{array}{l}\text { Ear } \\
\text { ly } \\
\text { Act } \\
\text { ion }\end{array}$ & $\begin{array}{c}5, \\
75 \\
0\end{array}$ & $\begin{array}{l}2,3 \\
27\end{array}$ & $\begin{array}{l}2002- \\
2016\end{array}$ & IFM & 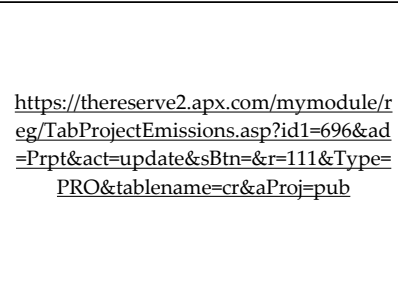 & $\begin{aligned} \frac{\mathrm{https}: / / \text { thereserve2.apx.co }}{\mathrm{m} / \mathrm{myM} \text { Module/rpt/myrpt. }} \\
\frac{\underline{\text { asp?r}=802 \& \mathrm{md}=\text { Prpt\&id1 }}}{\underline{=\% 20696}}\end{aligned}$ & $\begin{array}{l}\$(2002) \sim 6 \\
\text { months; } \\
\wedge \wedge(2012) \\
2011 \text { to } \\
2002 ; \\
\wedge \wedge(2015) \\
2014 \text { to } \\
2013 ; \\
\%(2016) \\
2015,2016\end{array}$ & $\begin{array}{l}\text { \%\%Project Submittal Form, } \\
\text { item 10. IFM-6, soil carbon } \\
\text { excluded }\end{array}$ \\
\hline $\begin{array}{l}2 \\
7\end{array}$ & $\frac{\text { CAR6 }}{\underline{97}}$ & $\begin{array}{c}\text { CAR114 } \\
7\end{array}$ & $\begin{array}{l}\text { CA } \\
\text { FR0 } \\
102\end{array}$ & $\begin{array}{c}\text { Tazewell - } \\
\text { Elk Garden } \\
\text { (Russell, } \\
\text { Washingto } \\
\text { n, and } \\
\text { Tazewell } \\
\text { Co. near } \\
\text { Tazewell, } \\
\text { VA) }\end{array}$ & $\begin{array}{c}- \\
81 . \\
55 \\
9\end{array}$ & $\begin{array}{l}37 \\
.1 \\
24\end{array}$ & $\begin{array}{l}\text { Allegheny \& } \\
\text { North } \\
\text { Cumberland } \\
\text { Mountains - } \\
\text { Mixed Pine } \\
\text { Hardwood, } \\
\text { Cove Forests, } \\
\text { Northern } \\
\text { Hardwoods, } \\
\text { Oak - Hickory }\end{array}$ & $\begin{array}{l}\text { Ear } \\
\text { ly } \\
\text { Act } \\
\text { ion }\end{array}$ & $\begin{array}{l}11 \\
, 6 \\
97\end{array}$ & $\begin{array}{l}4,7 \\
34\end{array}$ & $\begin{array}{l}2007- \\
2016\end{array}$ & IFM & $\begin{array}{c}\text { https://thereserve2.apx.com/mymodule/r } \\
\text { eg/TabProjectEmissions.asp?id1=697\&ad } \\
\text { =Prpt\&act=update\&sBtn=\&r=11\&Type=} \\
\text { PRO\&tablename=cr\&aProj=pub }\end{array}$ & $\begin{array}{c}\frac{\text { https://thereserve2.apx.co }}{\mathrm{m} / \mathrm{myyModule} / \mathrm{rpt} / \mathrm{myrpt}} \\
\frac{\underline{\text { asp?r=802\&md=Prpt\&id1 }}}{\underline{\equiv \% 20697}}\end{array}$ & $\begin{array}{l}\wedge \wedge(2014) 2 \\
013 \text { to } \\
2005 ; \\
\%(2014) \\
2015 \\
2016 ; \\
\%(2016) \\
2015,2016\end{array}$ & $\begin{array}{l}\text { \%\%Project Submittal Form, } \\
\text { item 10. IFM- } 6 \text {, soil carbon } \\
\text { excluded }\end{array}$ \\
\hline
\end{tabular}




\begin{tabular}{|c|c|c|c|c|c|c|c|c|c|c|c|c|c|c|c|c|}
\hline $\begin{array}{l}2 \\
8\end{array}$ & $\frac{\text { CAR7 }}{\underline{30}}$ & $\begin{array}{c}\text { CAR113 } \\
9\end{array}$ & $\begin{array}{l}\text { CA } \\
\text { FR0 } \\
123\end{array}$ & $\begin{array}{l}\text { Usal } \\
\text { Redwood } \\
\text { Forest } \\
\text { (Mendocin } \\
\text { o County, } \\
\text { CA) }\end{array}$ & $\begin{array}{c}- \\
12 \\
3.8 \\
47\end{array}$ & $\begin{array}{l}39 \\
.8 \\
76\end{array}$ & $\begin{array}{l}\text { Coast } \\
\text { Redwood/Doug } \\
\text { las-fir Mixed } \\
\text { Conifer }\end{array}$ & $\begin{array}{l}\text { Ear } \\
\text { ly } \\
\text { Act } \\
\text { ion }\end{array}$ & $\begin{array}{l}49 \\
, 0 \\
00\end{array}$ & $\begin{array}{c}19 \\
83 \\
0\end{array}$ & $\begin{array}{l}2007- \\
2017\end{array}$ & IFM & $\begin{array}{c}\text { https://thereserve2.apx.com/mymodule/r } \\
\text { eg/TabProjectEmissions.asp?id1=730\&ad } \\
=\text { Prpt\&act=update\&sBtn=\&r=111\&Type }= \\
\text { PRO\&tablename=cr\&aProj=pub }\end{array}$ & 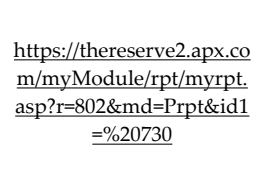 & $\begin{array}{l}\#(2007) ; \\
\$(2207) \sim 6 \\
\text { months; } \\
\wedge \wedge(2015) \\
2015 \text { to } \\
2007\end{array}$ & $\begin{array}{l}\% \% \text { Project Submittal Form, } \\
\text { item 10. IFM- } 6 \text {, soil carbon } \\
\text { excluded }\end{array}$ \\
\hline $\begin{array}{l}2 \\
9\end{array}$ & $\frac{\text { CAR7 }}{\underline{49}}$ & $\begin{array}{c}\text { CAR110 } \\
9\end{array}$ & $\begin{array}{l}\text { CA } \\
\text { FR0 } \\
063\end{array}$ & $\begin{array}{c}\text { Green } \\
\text { Assets - } \\
\text { Middleton } \\
\text { (Charlesto } \\
\mathrm{n}, \mathrm{SC})\end{array}$ & $\begin{array}{c}80 . \\
14 \\
1\end{array}$ & $\begin{array}{c}32 \\
.9\end{array}$ & $\begin{array}{l}\text { SE Middle } \\
\text { Mixed Forest } \\
\text { Piedmont } \\
\text { Atlantic Coastal } \\
\text { Plain \& } \\
\text { Flatwoods }\end{array}$ & $\begin{array}{l}\text { Ear } \\
\text { ly } \\
\text { Act } \\
\text { ion }\end{array}$ & $\begin{array}{c}3 \\
73 \\
2\end{array}$ & $\begin{array}{l}1,5 \\
10\end{array}$ & $\begin{array}{l}2007- \\
2017\end{array}$ & AC & $\begin{array}{c}\text { https://thereserve2.apx.com/mymodule/r } \\
\text { eg/TabProjectEmissions.asp?id1=749\&ad } \\
=\text { Prpt\&act=update\&sBtn=\&r=111\&Type }= \\
\text { PRO\&tablename=cr\&aProj=pub }\end{array}$ & 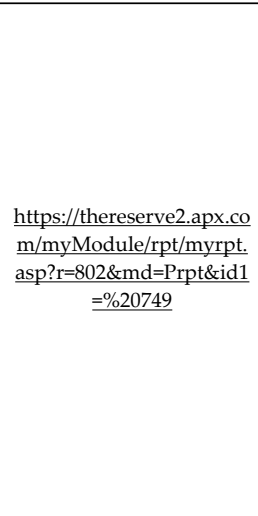 & $\begin{array}{l}\$(2007)< \\
1 \text { month; } \\
\wedge(2013) \\
2011 \\
\text { to2007; } \\
\$(2011) 20 \\
13,2014 ; \\
\wedge \wedge(2014) \\
2013 \text { to } \\
2011 ; \\
\%(2015) \\
2014 ; \\
2015 ; \\
\%(2016) \\
2015, \\
2016 ; \\
\%(2017) \\
2016,2017\end{array}$ & $\begin{array}{l}\text { \%\%Project Design } \\
\text { Document, Section 11.2.3 } \\
\text { Data gathering procedures } \\
\text { and parameters, AC-6, soil } \\
\text { carbon excluded, Table 5, } \\
\text { soil carbon emissions } \\
\text { excluded }\end{array}$ \\
\hline $\begin{array}{l}3 \\
0\end{array}$ & $\frac{\text { CAR7 }}{\underline{77}}$ & NA & $\begin{array}{l}\text { CA } \\
\text { FR0 } \\
064\end{array}$ & $\begin{array}{c}\text { Yurok } \\
\text { Tribe } \\
\text { Sustainable } \\
\text { Forest } \\
\text { Project } \\
\text { (Northwes } \\
\quad t \\
\text { Humboldt } \\
\text { County, } \\
\text { CA) }\end{array}$ & $\begin{array}{c}- \\
12 \\
3.8\end{array}$ & $\begin{array}{l}41 \\
.4 \\
06\end{array}$ & $\begin{array}{c}\text { Northern } \\
\text { California Coast } \\
\text { (Coast } \\
\text { Redwood/Doug } \\
\text { las Fir Mixed } \\
\text { Conifer) \& } \\
\text { Southern } \\
\text { Cascades } \\
\text { (Southern } \\
\text { Cascade Mixed } \\
\text { Conifer) }\end{array}$ & $\begin{array}{l}\text { Ear } \\
\text { ly } \\
\text { Act } \\
\text { ion }\end{array}$ & $\begin{array}{c}21 \\
, 2 \\
40\end{array}$ & $\begin{array}{l}8,5 \\
96\end{array}$ & $\begin{array}{l}2011- \\
2014\end{array}$ & IFM & $\begin{array}{c}\text { https://thereserve2.apx.com/mymodule/r } \\
\text { eg/TabProjectEmissions.asp?id1=777\&ad } \\
=\text { Prpt\&act=update\&sBtn=\&r=111\&Type }= \\
\text { PRO\&tablename=cr\&aProj=pub }\end{array}$ & $\begin{aligned} \frac{\mathrm{https}: / / \text { thereserve2.apx.co }}{\mathrm{m} / \mathrm{myM} \text { odule/rpt/myrpt. }} \\
\underline{\underline{\text { asp?r}=802 \& \mathrm{md}=\text { Prpt\&\&id1 }}} \\
\equiv=20777\end{aligned}$ & $\begin{array}{l}\#(2011) \\
\$(2011) \sim 8 \\
\text { months; } \\
\wedge \wedge(2014) \\
2013 \text { to } \\
2012\end{array}$ & $\begin{array}{l}\% \% \text { Project Desing } \\
\text { Document, Section } 3 . \\
\text { Inventory Methodology, } \\
\text { IFM-6, soil carbon excluded }\end{array}$ \\
\hline $\begin{array}{l}3 \\
1\end{array}$ & $\frac{\text { CAR7 }}{\underline{80}}$ & $\begin{array}{c}\text { CAR106 } \\
2\end{array}$ & $\begin{array}{l}\text { CA } \\
\text { FR0 } \\
088\end{array}$ & $\begin{array}{l}\text { Shannonda } \\
\text { le Tree } \\
\text { Farm } \\
\text { (Washingt } \\
\text { on County, } \\
\text { NC) }\end{array}$ & $\begin{array}{c}- \\
91 . \\
45\end{array}$ & $\begin{array}{l}37 \\
.3 \\
67\end{array}$ & $\begin{array}{l}\text { Atlantic Coastal } \\
\text { Plain - Atlantic } \\
\text { Coastal Plain } \\
\text { Swamp } \\
\text { Hardwood and } \\
\text { Cypress }\end{array}$ & $\begin{array}{l}\text { Ear } \\
\text { ly } \\
\text { Act } \\
\text { ion }\end{array}$ & $\begin{array}{l}40 \\
37\end{array}$ & $\begin{array}{l}1,6 \\
34\end{array}$ & $\begin{array}{l}2010- \\
2013\end{array}$ & $\mathrm{AC}$ & $\begin{array}{c}\text { https://thereserve2.apx.com/mymodule/r } \\
\text { eg/TabProjectEmissions.asp?id1=780\&ad } \\
=\text { Prpt\&act=update\&sBtn=\&r=111\&Type }= \\
\text { PRO\&tablename=cr\&aProj=pub }\end{array}$ & 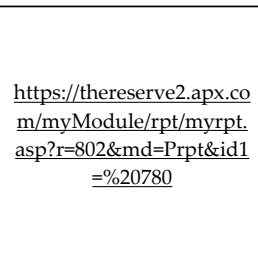 & $\begin{array}{l}\#(2013) ; \\
\$(2013) \sim 4 \\
\text { months; } \\
\wedge \wedge(2013) \\
2011 \text { to } \\
2010 ; \\
\wedge \wedge(2015) \\
2013 \text { to } \\
2012\end{array}$ & $\begin{array}{l}\text { \%\%Project Design } \\
\text { Document, Section A13. } \\
\text { Carbon Pools, IFM-6, soil } \\
\text { carbon excluded }\end{array}$ \\
\hline $\begin{array}{l}3 \\
2\end{array}$ & $\frac{\underline{C A R 8}}{\underline{02}}$ & NA & $\begin{array}{l}\text { CA } \\
\text { FR0 } \\
027\end{array}$ & $\begin{array}{l}\text { Noles } \\
\text { South } \\
\text { Forest } \\
\text { Project } \\
\text { (Washingt } \\
\text { on County, } \\
\text { NC) }\end{array}$ & $\begin{array}{c}- \\
76 . \\
54 \\
8\end{array}$ & $\begin{array}{l}35 \\
.8 \\
65\end{array}$ & $\begin{array}{l}\text { Atlantic Coastal } \\
\text { Plain - Atlantic } \\
\text { Coastal Plain } \\
\text { Swamp } \\
\text { Hardwood and } \\
\text { Cypress }\end{array}$ & $\begin{array}{l}\text { Ear } \\
\text { ly } \\
\text { Act } \\
\text { ion }\end{array}$ & $\begin{array}{c}32 \\
4\end{array}$ & $\begin{array}{c}13 \\
1\end{array}$ & $\begin{array}{l}2003- \\
2016\end{array}$ & AC & 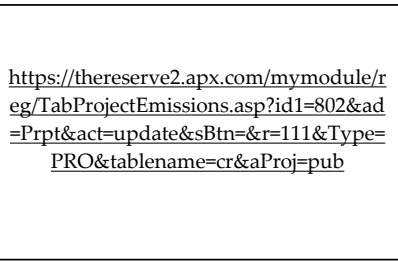 & $\begin{array}{l}\frac{\underline{\text { https://thereserve2.apx.co }}}{\mathrm{m} / \mathrm{myM} \text { Module/rpt/myrpt. }} \\
\frac{\text { asp?r=802\&md=Prpt\&id1 }}{\underline{\equiv \% 20802}}\end{array}$ & $\begin{array}{l}\$(2003) \sim 1 \\
\text { month; } \\
\wedge \wedge(2012) \\
2011 \text { to } \\
2003 ; \\
\$(5,180.0 \\
0) 2005 \text { to } \\
2009 ; \\
\$ \$(5,830.0 \\
\end{array}$ & $\begin{array}{l}\text { \%\%Project Design } \\
\text { Document, 11.2.3.4.1 Soil } \\
\text { carbon was sampled to } \\
\text { establish starting carbon } \\
\text { stocks } \\
\text { that would be degraded if } \\
\text { the baseline } \\
\text { scenario was followed, e.g. } \\
\text { full conversion to }\end{array}$ \\
\hline
\end{tabular}




\begin{tabular}{|c|c|c|c|c|c|c|c|c|c|c|c|c|c|c|c|c|}
\hline & & & & & & & & & & & & & & & $\begin{array}{l}\text { 0) 2011, } \\
2012\end{array}$ & $\begin{array}{l}\text { agricultural use. The soil } \\
\text { carbon was excluded as } \\
\text { source of } \mathrm{CO} 2 \text { over the } \\
\text { lifetime of the project (e.g." } \\
\text { AC-6) }\end{array}$ \\
\hline $\begin{array}{l}3 \\
3\end{array}$ & $\frac{\text { CAR9 }}{\underline{35}}$ & NA & NA & $\begin{array}{l}\text { Arcata } \\
\text { City } \\
\text { Barnum } \\
\text { Tract } \\
\text { (Arcata, } \\
\text { CA) }\end{array}$ & $\begin{array}{c}- \\
12 \\
4.0 \\
49\end{array}$ & $\begin{array}{l}40 \\
.8 \\
76\end{array}$ & $\begin{array}{l}\text { Northern } \\
\text { California Coast } \\
\text { Redwood/Doug } \\
\text { las-fir Mixed } \\
\text { Conifer }\end{array}$ & $\begin{array}{c}\text { No } \\
t \\
\text { Eli } \\
\text { gib } \\
\text { le }\end{array}$ & $\begin{array}{c}28 \\
0\end{array}$ & $\begin{array}{c}11 \\
3\end{array}$ & $\begin{array}{l}2003- \\
2016\end{array}$ & IFM & 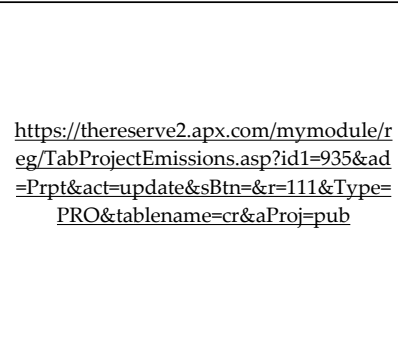 & $\begin{array}{l}\frac{\frac{\text { https://thereserve2.apx.co }}{\text { m/myModule/rpt/myrpt. }}}{\underline{\text { asp?r=802\&md=Prpt\&id1 }}} \\
\underline{=\% 20935}\end{array}$ & $\begin{array}{l}\$(2003) \\
\sim 11 \\
\text { months; } \\
\wedge \wedge(2012) \\
2011 \text { to } \\
2003 ; \\
\$ \$(2,904.0 \\
0) 2005 \text { to } \\
2011 ; \\
\$(2,527.0 \\
\text { 0) 2012 to } \\
2016\end{array}$ & $\begin{array}{l}\text { \%\%Project Design } \\
\text { Document, Section Step } 4 . \\
\text { Determine the baseline } \\
\text { carbon stocks over } 100 \text { year } \\
\text { for all required and optiona } \\
\text { carbon pools in the Project } \\
\text { Area, IFM-6. soil carbon } \\
\text { excluded }\end{array}$ \\
\hline $\begin{array}{l}3 \\
4\end{array}$ & $\frac{\underline{\text { CAR1 }}}{\underline{013}}$ & NA & $\begin{array}{l}\text { CA } \\
\text { FR5 } \\
055\end{array}$ & $\begin{array}{l}\text { Buckeye } \\
\text { Forest } \\
\text { Project } \\
\text { (Sonoma } \\
\text { County, } \\
\text { CA) }\end{array}$ & $\begin{array}{c}- \\
12 \\
3.3 \\
1\end{array}$ & $\begin{array}{l}38 \\
.7 \\
4\end{array}$ & $\begin{array}{l}\text { Coast Redwood } \\
\text { / Douglas-fir } \\
\text { Mixed Conifer } \\
\text { and Northern } \\
\text { California Coast } \\
\text { Mixed Oak } \\
\text { Woodland }\end{array}$ & $\begin{array}{l}\text { Co } \\
\mathrm{mp} \\
\text { lia } \\
\text { nce }\end{array}$ & $\begin{array}{c}19 \\
, 5 \\
25\end{array}$ & $\begin{array}{c}7,9 \\
01\end{array}$ & $\begin{array}{r}2014- \\
2017\end{array}$ & IFM & $\begin{array}{l}\frac{h \text { https://thereserve2.apx.com/mymodule/r }}{\text { eg/TabProjectEmissions.asp?id11=1013\&a }} \\
\frac{\text { d=Prpt\&act=update\&sBtn=\&r=111\&Type }}{\text { =PRO\&tablename=cr\&aProj=pub }}\end{array}$ & NA & $\begin{array}{l}\#(2014) ; \\
\$ \%(2014) ; \\
\$ \%(2015) ; \\
\$ \%(2016) ; \\
\$ \%(2017) ;\end{array}$ & $\begin{array}{l}\text { \%\%Application for Listing, } \\
\text { Part VII, Carbon Stock } \\
\text { Inventory, IMF-6, Not } \\
\text { applicable }\end{array}$ \\
\hline $\begin{array}{l}3 \\
5\end{array}$ & $\frac{\underline{\text { CAR1 }}}{\underline{015}}$ & NA & $\begin{array}{l}\text { CA } \\
\text { FR0 } \\
100\end{array}$ & $\begin{array}{l}\text { Rips } \\
\text { Redwoods } \\
\text { (Sonoma } \\
\text { County, } \\
\text { CA) }\end{array}$ & $\begin{array}{c}- \\
12 \\
3.2 \\
12\end{array}$ & $\begin{array}{l}38 \\
.7 \\
11\end{array}$ & $\begin{array}{l}\text { Coast Redwood } \\
\text { / Douglas-fir } \\
\text { Mixed Conifer } \\
\text { and Northern } \\
\text { California Coast } \\
\text { Mixed Oak } \\
\text { Woodland }\end{array}$ & $\begin{array}{l}\text { Ear } \\
\text { ly } \\
\text { Act } \\
\text { ion }\end{array}$ & $\begin{array}{l}14 \\
26\end{array}$ & $\begin{array}{c}57 \\
7\end{array}$ & $\begin{array}{l}2013- \\
2014\end{array}$ & IFM & $\begin{array}{l}\frac{\text { https://thereserve2.apx.com/mymodule/r }}{\text { eg/TabProjectEmissions.asp?id11=1015\&a }} \\
\frac{\text { d=Prpt\&act=update\&sBtn=\&r=111\&Type }}{\text { ERO\&tablename=cr\&aProj=pub }}\end{array}$ & $\begin{array}{l}\frac{\text { https://thereserve2.apx.co }}{\text { m/myModule/rpt/myrpt. }} \\
\underline{\text { asp?r=802\&md=Prpt\&id1 }} \\
=\% 201015\end{array}$ & $\begin{array}{l}\#(2013) ; \\
\$(2013) \sim 7 \\
\text { months }\end{array}$ & $\begin{array}{l}\% \% \text { Project Design } \\
\text { Document, Section 2.B.B. } \\
\text { Carbon Sinks, Sources and } \\
\text { Reservoirs, IFM-6, absent }\end{array}$ \\
\hline $\begin{array}{l}3 \\
6\end{array}$ & $\frac{\underline{C A R 1}}{\underline{032}}$ & NA & $\begin{array}{l}\text { CA } \\
\text { FR5 } \\
037\end{array}$ & $\begin{array}{c}\text { Virginia } \\
\text { Highlands } \\
\text { I (Russell, } \\
\text { Buchanan } \\
\text { and } \\
\text { Dickenson } \\
\text { Counties, } \\
\text { VA) }\end{array}$ & $\begin{array}{c}- \\
82 . \\
34 \\
7\end{array}$ & $\begin{array}{l}37 \\
.0 \\
85\end{array}$ & $\begin{array}{l}\text { oak-hickory, } \\
\text { loblolly- } \\
\text { shortleaf pine, } \\
\text { and mixed oak- } \\
\text { pine }\end{array}$ & $\begin{array}{l}\text { Co } \\
\mathrm{mp} \\
\text { lia } \\
\text { nce }\end{array}$ & $\begin{array}{c}9, \\
75 \\
3\end{array}$ & $\begin{array}{l}3,9 \\
47\end{array}$ & 2013 & IFM & $\begin{array}{l}\frac{\text { https://thereserve2.apx.com/mymodule/r }}{\text { eg/TabProjectEmissions.asp?id11 } 1032 \& a} \\
\frac{\text { d=Prpt\&act=update\&sBtn=\&r=111\&Type }}{\text { ERO\&tablename=cr\&aProj=pub }}\end{array}$ & NA & $\begin{array}{l}\#(2013) ; \\
\$(2013) \sim \\
7 \text { months }\end{array}$ & $\begin{array}{l}\text { \%\%Application for Listing, } \\
\text { Part VII, Carbon Stock } \\
\text { Inventory, IMF-6, Not } \\
\text { applicable }\end{array}$ \\
\hline $\begin{array}{l}3 \\
7\end{array}$ & $\frac{\underline{C A R 1}}{\underline{041}}$ & NA & $\begin{array}{l}\text { CA } \\
\text { FR5 } \\
038\end{array}$ & $\begin{array}{c}\text { Sacrament } \\
\text { o Canyon } \\
\text { ARB001 } \\
\text { (Shasta } \\
\text { County, } \\
\text { CA) }\end{array}$ & $\begin{array}{c}- \\
12 \\
2.2 \\
9\end{array}$ & $\begin{array}{l}41 \\
.0 \\
5\end{array}$ & $\begin{array}{l}\text { Southern } \\
\text { Cascade, Mixed } \\
\text { Conifer }\end{array}$ & $\begin{array}{l}\text { Co } \\
\mathrm{mp} \\
\text { lia } \\
\text { nce }\end{array}$ & $\begin{array}{r}16 \\
9 \\
41\end{array}$ & $\begin{array}{l}6,8 \\
56\end{array}$ & $\begin{array}{l}2015- \\
2017\end{array}$ & IFM & $\begin{array}{l}\frac{\text { https://thereserve2.apx.com/mymodule/r }}{\text { eg/TabProjectEmissions.asp?id11 } 1041 \& a} \\
\frac{\text { d=Prpt\&act=update\&sBtn=\&r=111\&Type }}{\text { ERO\&tablename=cr\&aProj=pub }}\end{array}$ & NA & $\begin{array}{l}\#(2015) ; \\
\%(2015) \\
2013, \\
2014, \\
2015 ; \\
\$(2016) \\
2015, \\
2016 ; \\
\$(2017) \\
2016,2017\end{array}$ & $\begin{array}{l}\text { \%\%Application for Listing, } \\
\text { Part VII, Carbon Stock } \\
\text { Inventory, IMF-6, Not } \\
\text { applicable }\end{array}$ \\
\hline 3 & CAR1 & NA & $\begin{array}{l}\text { CA } \\
\text { FR5 }\end{array}$ & $\begin{array}{c}\text { Trinity } \\
\text { Timberlan }\end{array}$ & - & $\begin{array}{l}40 \\
.5\end{array}$ & $\begin{array}{c}\text { "Northern } \\
\text { California Coast }\end{array}$ & $\begin{array}{l}\text { Co } \\
\mathrm{mp}\end{array}$ & $\begin{array}{c}11 \\
9\end{array}$ & 4,8 & 2014 & IFM & $\begin{array}{l}\text { https://thereserve2.apx.com/mymodule/r } \\
\text { eg/TabProjectEmissions.asp?id1=1046\&a }\end{array}$ & NA & $\begin{array}{l}\#(2014) ; \\
\$(2013)\end{array}$ & $\begin{array}{l}\text { \%\%Application for Listing, } \\
\text { Part VII, Carbon Stock }\end{array}$ \\
\hline
\end{tabular}




\begin{tabular}{|c|c|c|c|c|c|c|c|c|c|c|c|c|c|c|c|c|}
\hline 8 & $\underline{046}$ & & 076 & $\begin{array}{c}\mathrm{ds} \\
\text { University } \\
\text { Hill Project } \\
\text { (Trinity } \\
\text { County, } \\
\text { CA) }\end{array}$ & 3.5 & 8 & $\begin{array}{c}\text { (Coast } \\
\text { Redwood/Doug } \\
\text { las Fir Mixed } \\
\text { Conifer) \& } \\
\text { Southern } \\
\text { Cascades } \\
\text { (Southern } \\
\text { Cascade Mixed } \\
\text { Conifer)" }\end{array}$ & $\begin{array}{l}\text { lia } \\
\text { nce }\end{array}$ & 00 & 16 & & & $\begin{array}{c}\frac{\mathrm{d}=\text { Prpt\&act=update\&sBtn=\&r=111\&Type }}{} \\
\underline{=\text { PRO\&tablename }=\text { cr\&aProj=pub }}\end{array}$ & & $\begin{array}{l}\sim 10 \\
\text { months; } \\
\%(2013) \\
2013,2014\end{array}$ & $\begin{array}{l}\text { Inventory, IMF-6, Not } \\
\text { applicable (Attachment E) }\end{array}$ \\
\hline $\begin{array}{l}3 \\
9\end{array}$ & $\underline{\underline{\text { CAR1 } 1}}$ & NA & $\begin{array}{l}\text { CA } \\
\text { FR5 } \\
058\end{array}$ & $\begin{array}{c}\text { Buck } \\
\text { Mountain } \\
\text { ARB002 } \\
\text { (Siskiyou } \\
\text { County, } \\
\text { CA) }\end{array}$ & $\begin{array}{c}- \\
12 \\
1.8 \\
5\end{array}$ & $\begin{array}{l}41 \\
.3 \\
8\end{array}$ & $\begin{array}{l}\text { Southern } \\
\text { Cascade, Mixed } \\
\text { Conifer }\end{array}$ & $\begin{array}{l}\text { Co } \\
\text { mp } \\
\text { lia } \\
\text { nce }\end{array}$ & $\begin{array}{l}12 \\
4 \\
86\end{array}$ & $\begin{array}{l}5,0 \\
53\end{array}$ & $\begin{array}{r}2015- \\
2017\end{array}$ & IFM & $\begin{array}{c}\text { https://thereserve2.apx.com/mymodule/r } \\
\text { eg/TabProjectEmissions.asp?id111066\&a } \\
\begin{array}{c}\text { d=Prpt\&act=update\&sBtn=\&r=111\&Type } \\
\text { =PRO\&tablename=cr\&aProj=pub }\end{array}\end{array}$ & NA & $\begin{array}{l}\#(2015) ; \\
\$(2015) \sim 9 \\
\text { months; } \\
\%(2015) \\
2014 ; \\
2015 ; \\
\$(2016) 20 \\
15,2016 ; \\
\$(2017) \\
2016,2017\end{array}$ & $\begin{array}{l}\text { \%\%Application for Listing, } \\
\text { Part VII, Carbon Stock } \\
\text { Inventory, IMF-6, Not } \\
\text { applicable }\end{array}$ \\
\hline $\begin{array}{l}4 \\
0\end{array}$ & $\frac{\text { CAR1 }}{\underline{067}}$ & NA & $\begin{array}{l}\text { CA } \\
\text { FR5 } \\
063\end{array}$ & $\begin{array}{c}\text { Sustainable } \\
\text { Mountain } \\
\text { (Humboldt } \\
\text { County, } \\
\text { CA (near } \\
\text { Willow } \\
\text { Creek) }\end{array}$ & $\begin{array}{c}- \\
12 \\
3.7 \\
6\end{array}$ & $\begin{array}{l}40 \\
.9 \\
1\end{array}$ & $\begin{array}{l}\text { Douglas Fir } \\
\text { Mixed Conifer }\end{array}$ & $\begin{array}{l}\text { Co } \\
\text { mp } \\
\text { lia } \\
\text { nce }\end{array}$ & $\begin{array}{c}2 \\
11 \\
2\end{array}$ & $\begin{array}{c}85 \\
5\end{array}$ & 2015 & IFM & 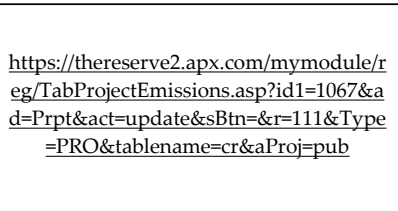 & NA & $\begin{array}{l}\$(2014) \sim \\
6 \text { months; } \\
\%(2014) \\
2013,2014\end{array}$ & $\begin{array}{l}\text { \%\%Application for Listing, } \\
\text { Part VII, Carbon Stock } \\
\text { Inventory, IMF-6, excluded }\end{array}$ \\
\hline $\begin{array}{l}4 \\
1\end{array}$ & $\frac{\text { CAR1 }}{\underline{092}}$ & NA & $\begin{array}{l}\text { CA } \\
\text { FR5 } \\
087\end{array}$ & $\begin{array}{l}\text { Big Valley } \\
\text { (Near } \\
\text { Aiden, CA) }\end{array}$ & $\begin{array}{c}12 \\
1.2 \\
4\end{array}$ & $\begin{array}{l}41 \\
.1 \\
3\end{array}$ & $\begin{array}{l}\text { Douglas Fir } \\
\text { Mixed Conifer }\end{array}$ & $\begin{array}{l}\text { Act } \\
\text { ive }\end{array}$ & $\begin{array}{l}14 \\
, 6 \\
22\end{array}$ & $\begin{array}{l}5,9 \\
17\end{array}$ & 2016 & IFM & $\begin{array}{c}\text { https://thereserve2.apx.com/mymodule/r } \\
\text { eg/TabProjectEmissions.asp?id1=1092\&a } \\
\begin{array}{c}\text { d=Prpt\&act=update\&sBtn=\&r=111\&Type } \\
\text { =PRO\&tablename=cr\&aProj=pub }\end{array}\end{array}$ & NA & $\begin{array}{l}\#(2016) ; \\
\%(2016) \\
2014, \\
2015,2016\end{array}$ & $\begin{array}{l}\text { \%\%Application for Listing, } \\
\text { Part VII, Carbon Stock } \\
\text { Inventory, IMF-6, Not } \\
\text { applicable }\end{array}$ \\
\hline $\begin{array}{l}4 \\
2\end{array}$ & $\frac{\underline{\mathrm{CAR} 1}}{\underline{094}}$ & NA & $\begin{array}{l}\text { CA } \\
\text { FR5 } \\
095\end{array}$ & $\begin{array}{l}\text { Ashford III } \\
\text { (Ashford, } \\
\text { WA) }\end{array}$ & $\begin{array}{c}- \\
12 \\
2.0 \\
4\end{array}$ & $\begin{array}{l}46 \\
.4 \\
6\end{array}$ & $\begin{array}{l}\text { Northwest } \\
\text { Cascade Mixed } \\
\text { Conifer }\end{array}$ & $\begin{array}{l}\text { Co } \\
\text { mp } \\
\text { lia } \\
\text { nce }\end{array}$ & $\begin{array}{l}52 \\
90\end{array}$ & $\begin{array}{l}2,1 \\
41\end{array}$ & 2014 & IFM & $\begin{array}{l}\frac{h \text { https://thereserve2.apx.com/mymodule/r }}{\text { eg/TabProjectEmissions.asp?id1=1094\&a }} \\
\begin{array}{c}\text { d=Prpt\&act=update\&sBtn=\&r=111\&Type } \\
\text { =PRO\&tablename=cr\&aProj=pub }\end{array}\end{array}$ & NA & $\begin{array}{l}\#(2014) ; \\
\%(2014) \\
2012, \\
2013,2014\end{array}$ & $\begin{array}{l}\text { \%\%Application for Listing, } \\
\text { Part VII, Carbon Stock } \\
\text { Inventory, IMF-6, Not } \\
\text { applicable }\end{array}$ \\
\hline $\begin{array}{l}4 \\
3\end{array}$ & $\frac{\text { CAR1 }}{\underline{095}}$ & NA & $\begin{array}{l}\text { CA } \\
\text { FR5 } \\
096\end{array}$ & $\begin{array}{l}\text { Brushy } \\
\text { Mountain } \\
\text { (Mendocin } \\
\text { o County, } \\
\text { CA) }\end{array}$ & $\begin{array}{c}12 \\
3.2 \\
6\end{array}$ & $\begin{array}{l}39 \\
.6 \\
3\end{array}$ & $\begin{array}{l}\text { Southern } \\
\text { Cascade Mixed } \\
\text { Conifer }\end{array}$ & $\begin{array}{l}\text { Co } \\
\text { mp } \\
\text { lia } \\
\text { nce }\end{array}$ & $\begin{array}{l}16 \\
, 3 \\
92\end{array}$ & $\begin{array}{l}6,6 \\
34\end{array}$ & $\begin{array}{r}2014- \\
2017\end{array}$ & IFM & 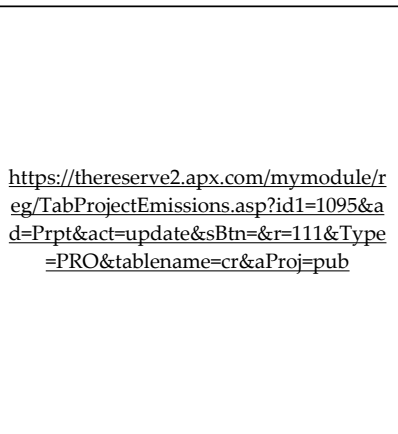 & NA & $\begin{array}{l}\#(2014) ; \\
\$(2014) \sim \\
8 \text { months; } \\
\$(2016) \\
2015, \\
2016 ; \\
\%(2015) \\
2014 ; \\
2015 ; \\
\%(2016) \\
2015 ; \\
2016 ; \\
\%(2017) \\
2016 ; \\
2017 ;\end{array}$ & $\begin{array}{l}\text { \%\%Application for Listing, } \\
\text { Part VII, Carbon Stock } \\
\text { Inventory, IMF-6, excluded } \\
\text { (Addendum to Listing } \\
\text { Application) }\end{array}$ \\
\hline 4 & CAR1 & NA & $\begin{array}{l}\text { CA } \\
\text { FR5 }\end{array}$ & $\begin{array}{c}\text { Montesol } \\
\text { Forest }\end{array}$ & - & $\begin{array}{l}38 \\
.6\end{array}$ & $\begin{array}{c}\text { Southern } \\
\text { Cascade Mixed }\end{array}$ & $\begin{array}{l}\text { Co } \\
\mathrm{mp}\end{array}$ & $\begin{array}{l}3, \\
10\end{array}$ & 1,2 & 2016 & IFM & $\begin{array}{l}\text { https://thereserve2.apx.com/mymodule/r } \\
\text { eg/TabProjectEmissions.asp?id1=1102\&a }\end{array}$ & NA & $\begin{array}{l}\#(2016) ; \\
\$(2016) \sim\end{array}$ & $\begin{array}{l}\text { \%\%Application for Listing, } \\
\text { Part VII, Carbon Stock }\end{array}$ \\
\hline
\end{tabular}




\begin{tabular}{|c|c|c|c|c|c|c|c|c|c|c|c|c|c|c|c|c|}
\hline 4 & $\underline{102}$ & & 148 & $\begin{array}{l}\text { Carbon } \\
\text { (Napa and } \\
\text { Lake } \\
\text { County, } \\
\text { CA) }\end{array}$ & $\begin{array}{l}2.5 \\
64\end{array}$ & 71 & Conifer & $\begin{array}{l}\text { lia } \\
\text { nce }\end{array}$ & 2 & 55 & & & $\frac{d=\text { Prpt\&act=update\&sBtn=\&r=111\&Type }}{\equiv \text { PRO\&tablename=cr\&aProj=pub }}$ & & 7 months & $\begin{array}{l}\text { Inventory, IMF-6, Not } \\
\text { applicable }\end{array}$ \\
\hline $\begin{array}{l}4 \\
5\end{array}$ & $\frac{\underline{\text { CAR1 }}}{\underline{103}}$ & NA & $\begin{array}{l}\text { CA } \\
\text { FR5 } \\
149\end{array}$ & $\begin{array}{c}\text { Forest } \\
\text { Carbon } \\
\text { Partners - } \\
\text { Glass } \\
\text { Ranch } \\
\text { Improved } \\
\text { Forest } \\
\text { Manageme } \\
\text { nt Project } \\
\text { (Humboldt } \\
\text { County, } \\
\text { CA) }\end{array}$ & $\begin{array}{c}- \\
12 \\
3.6 \\
44\end{array}$ & $\begin{array}{l}40 \\
.3 \\
46\end{array}$ & $\begin{array}{c}\text { Southern } \\
\text { Cascade Mixed } \\
\text { Conifer }\end{array}$ & $\begin{array}{l}\text { Co } \\
\text { mp } \\
\text { lia } \\
\text { nce }\end{array}$ & $\begin{array}{l}22 \\
, 6 \\
76\end{array}$ & $\begin{array}{l}9,1 \\
77\end{array}$ & 2015 & IFM & 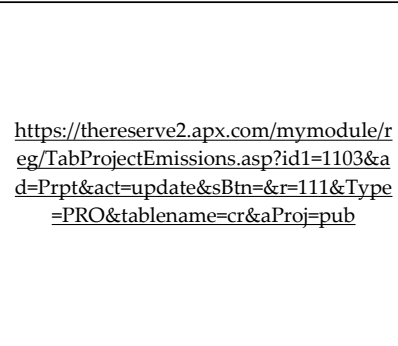 & NA & $\begin{array}{l}\#(2015) ; \\
\%(2015) \\
2014,2015\end{array}$ & $\begin{array}{l}\text { \%\%Application for Listing } \\
\text { Part VII, Carbon Stock } \\
\text { Inventory, IMF-6, Not } \\
\text { applicable }\end{array}$ \\
\hline $\begin{array}{l}4 \\
6\end{array}$ & $\frac{\text { CAR1 }}{\underline{104}}$ & NA & $\begin{array}{l}\text { CA } \\
\text { FR5 } \\
150\end{array}$ & $\begin{array}{c}\text { Forest } \\
\text { Carbon } \\
\text { Partners - } \\
\text { Gabrych } \\
\text { Ranch } \\
\text { Project } \\
\text { (Humboldt } \\
\text { County } \\
\text { and Trinity } \\
\text { County, } \\
\text { CA) }\end{array}$ & $\begin{array}{c}- \\
12 \\
3.6 \\
06\end{array}$ & $\begin{array}{l}40 \\
.7 \\
13\end{array}$ & $\begin{array}{l}\text { Southern } \\
\text { Cascade Mixed } \\
\text { Conifer }\end{array}$ & $\begin{array}{l}\text { Co } \\
\text { mp } \\
\text { lia } \\
\text { nce }\end{array}$ & $\begin{array}{c}4, \\
03 \\
9\end{array}$ & $\begin{array}{l}1,6 \\
35\end{array}$ & 2015 & IFM & $\begin{array}{l}\frac{h t t p s: / / \text { thereserve2.apx.com/mymodule/r }}{\text { eg/TabProjectEmissions.asp?id11=1104\&a }} \\
\frac{\text { d=Prpt\&act=update\&sBtn=\&r=111\&Type }}{\text { =PRO\&tablename=cr\&aProj=pub }}\end{array}$ & NA & $\begin{array}{l}\#(2015) ; \\
\%(2015) \\
2014,2015\end{array}$ & $\begin{array}{l}\text { \%\%Application for Listing } \\
\text { Part VII, Carbon Stock } \\
\text { Inventory, IMF-6, Not } \\
\text { applicable }\end{array}$ \\
\hline $\begin{array}{l}4 \\
7\end{array}$ & $\frac{\text { CAR1 }}{\underline{114}}$ & NA & $\begin{array}{l}\text { CA } \\
\text { FR5 } \\
114\end{array}$ & $\begin{array}{l}\text { Crane } \\
\text { Valley }\end{array}$ & $\begin{array}{l}12 \\
3.6 \\
06\end{array}$ & $\begin{array}{l}40 \\
.7 \\
13\end{array}$ & $\begin{array}{c}\text { Southern } \\
\text { Cascade Mixed } \\
\text { Oak Woodland } \\
\text { and Sierra } \\
\text { Mixed Oak } \\
\text { Woodland }\end{array}$ & $\begin{array}{l}\text { Co } \\
\text { mp } \\
\text { lia } \\
\text { nce }\end{array}$ & $\begin{array}{l}19 \\
, 3 \\
84\end{array}$ & $\begin{array}{r}7,8 \\
44\end{array}$ & 2016 & IFM & $\begin{array}{l}\underline{\text { https://thereserve2.apx.com/mymodule/r }} \\
\text { eg/TabProjectEmissions.asp?r }=111 \& \text { \&ad=P } \\
\text { rpt\&act=update\&type=PRO\&aProj=pub\& } \\
\text { tablename=cr\&id1=1114 }\end{array}$ & NA & $\begin{array}{l}\#(2016) ; \\
\%(2016) \\
2014, \\
2015,2016\end{array}$ & $\begin{array}{l}\text { \%\%PART VII. CARBON } \\
\text { STOCK INVENTORY } \\
\text { IFM-6 Soil (if applicable): } \\
\text { N/A }\end{array}$ \\
\hline $\begin{array}{l}4 \\
8\end{array}$ & $\frac{\underline{\text { CAR1 }}}{\underline{175}}$ & NA & $\begin{array}{l}\text { CA } \\
\text { FR5 } \\
195\end{array}$ & $\begin{array}{c}\text { Finite } \\
\text { Carbon- } \\
\text { Passamaqu } \\
\text { oddy Tribe } \\
\text { (Frankin, } \\
\text { Somerset, } \\
\text { Penobscot, } \\
\text { Hancock, } \\
\text { and } \\
\text { Washingto } \\
\text { n Counties, } \\
\text { ME) }\end{array}$ & $\begin{array}{c}- \\
67 . \\
63\end{array}$ & $\begin{array}{l}45 \\
.2 \\
88\end{array}$ & $\begin{array}{c}\text { New Brunswick } \\
\text { Foothills \& } \\
\text { Lowlands, } \\
\text { White } \\
\text { Mountains } \\
\text { Mixed } \\
\text { Hardwoods }\end{array}$ & $\begin{array}{l}\text { Co } \\
\text { mp } \\
\text { lia } \\
\text { nce }\end{array}$ & $\begin{array}{r}98 \\
, 4 \\
92\end{array}$ & $\begin{array}{c}39 \\
85 \\
8\end{array}$ & $\begin{array}{l}2015- \\
2016\end{array}$ & IFM & 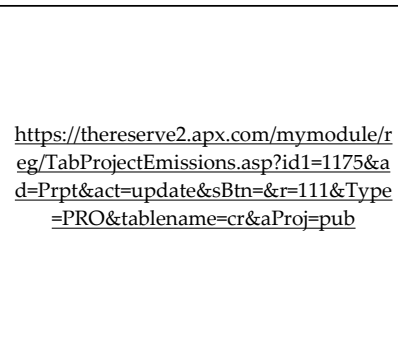 & NA & $\begin{array}{l}\#(2015) ; \\
\%(2015) \\
2014 \\
2015 ; \\
\%(2016) \\
2015, \\
2016 ; \\
\%(2016) \\
2015,2016\end{array}$ & $\begin{array}{l}\% \% \text { PART VII. CARBON } \\
\text { STOCK INVENTORY } \\
\text { IFM-6 Soil (if applicable): } \\
\text { Excluded }\end{array}$ \\
\hline $\begin{array}{l}4 \\
9\end{array}$ & $\frac{\underline{\text { CAR1 }}}{\underline{180}}$ & NA & $\begin{array}{l}\text { CA } \\
\text { FR5 } \\
280\end{array}$ & $\begin{array}{l}\text { Maillard } \\
\text { Ranch } \\
\text { (Mendocin } \\
\text { o County, } \\
\text { CA) }\end{array}$ & $\begin{array}{c}- \\
12 \\
3.3 \\
6\end{array}$ & $\begin{array}{r}39 \\
.9 \\
2\end{array}$ & $\begin{array}{l}\text { Temperate } \\
\text { coniferous }\end{array}$ & $\begin{array}{l}\text { Co } \\
\text { mp } \\
\text { lia } \\
\text { nce }\end{array}$ & $\begin{array}{l}12 \\
, 3 \\
60\end{array}$ & $\begin{array}{l}5,0 \\
02\end{array}$ & 2016 & IFM & $\begin{array}{l}\frac{\text { https://thereserve2.apx.com/mymodule/r }}{\text { eg/TabProjectEmissions.asp?id11=1180\&a }} \\
\frac{\text { d=Prpt\&act=update\&sBtn=\&r=111\&Type }}{\text { ERO\&tablename=cr\&aProj=pub }}\end{array}$ & NA & $\begin{array}{l}\#(2016) ; \\
\%(2016) \\
2015,2016\end{array}$ & $\begin{array}{l}\% \% \text { PART VII. CARBON } \\
\text { STOCK INVENTORY } \\
\text { IFM-6 Soil (if applicable): } \\
\text { Excluded" }\end{array}$ \\
\hline
\end{tabular}




\begin{tabular}{|c|c|c|c|c|c|c|c|c|c|c|c|c|c|c|c|c|}
\hline $\begin{array}{l}5 \\
0\end{array}$ & $\frac{\frac{\text { CAR1 } 1}{\underline{183}}}{2}$ & NA & $\begin{array}{l}\text { CA } \\
\text { FR5 } \\
283\end{array}$ & $\begin{array}{c}\text { Forest } \\
\text { Carbon } \\
\text { Partners- } \\
\text { Mescalero } \\
\text { Apache } \\
\text { Tribe } \\
\text { (Otero \& } \\
\text { Lincoln } \\
\text { County, } \\
\text { NM) }\end{array}$ & $\begin{array}{c}- \\
10 \\
5.6 \\
5\end{array}$ & $\begin{array}{l}33 \\
.1 \\
7\end{array}$ & $\begin{array}{l}\text { Red Spruce and } \\
\text { Eastern } \\
\text { Hemlock }\end{array}$ & $\begin{array}{l}\text { Co } \\
\mathrm{mp} \\
\text { lia } \\
\text { nce }\end{array}$ & $\begin{array}{c}22 \\
1, \\
82 \\
2\end{array}$ & $\begin{array}{c}89 \\
76 \\
8\end{array}$ & 2016 & IFM & $\begin{array}{l}\frac{h \text { htps://thereserve2.apx.com/mymodule/r }}{\text { eg/TabProjectEmissions.asp?r=111\&ad=P }} \\
\text { rpt\&act=update\&type=PRO\&aProj=pub\& } \\
\text { tablename=cr\&id1=1183 }\end{array}$ & $\mathrm{NA}$ & $\begin{array}{l}\#(2016) ; \\
\$(2016) \\
\sim 10 \\
\text { months; } \\
\%(2016) \\
2015,2016\end{array}$ & $\begin{array}{l}\text { \%\%PART VII. CARBON } \\
\text { STOCK INVENTORY } \\
\text { IFM-6 Soil (if applicable): } \\
\text { Not Applicable }\end{array}$ \\
\hline $\begin{array}{l}5 \\
1\end{array}$ & $\frac{\text { CAR1 }}{\underline{191}}$ & NA & $\begin{array}{l}\text { CA } \\
\text { FR5 } \\
291\end{array}$ & $\begin{array}{l}\text { Hollow } \\
\text { Tree } \\
\text { (Mendocin } \\
\text { o County, } \\
\text { CA) }\end{array}$ & $\begin{array}{c}- \\
12 \\
3.7 \\
82\end{array}$ & $\begin{array}{l}39 \\
.8 \\
5\end{array}$ & $\begin{array}{l}\text { Coast } \\
\text { Redwood/Doug } \\
\text { las-fir Mixed } \\
\text { Conifer }\end{array}$ & $\begin{array}{l}\text { Co } \\
\mathrm{mp} \\
\text { lia } \\
\text { nce }\end{array}$ & $\begin{array}{l}20 \\
, 2 \\
95\end{array}$ & $\begin{array}{l}8,2 \\
13\end{array}$ & 2016 & IFM & $\begin{array}{l}\frac{h \text { htps://thereserve2.apx.com/mymodule/r }}{\text { eg/TabDocuments.asp?r=111\&ad=Prpt\&a }} \\
\frac{\text { ct=update\&type=PRO\&aProj=pub\&table }}{\underline{\text { name=doc\&id1 }=1191}}\end{array}$ & NA & $\begin{array}{l}\#(2016) ; \\
\%(2016) \\
2015,2016\end{array}$ & $\begin{array}{l}\text { \%\%PART VII. CARBON } \\
\text { STOCK INVENTORY } \\
\text { IFM-6 Soil (if applicable): } \\
\text { Not Applicable }\end{array}$ \\
\hline $\begin{array}{l}5 \\
2\end{array}$ & $\frac{\text { CAR1 }}{\underline{197}}$ & NA & $\begin{array}{l}\text { CA } \\
\text { FR5 } \\
297\end{array}$ & $\begin{array}{c}\text { Upper } \\
\text { Hudson } \\
\text { Woodland } \\
\text { s ATP, LP } \\
\text { (Warren, } \\
\text { Hamilton, } \\
\text { Essex, } \\
\text { Washingto } \\
\text { n, Saratoga } \\
\text { and } \\
\text { Fulton, } \\
\text { NY) }\end{array}$ & $\begin{array}{c}- \\
74 . \\
33\end{array}$ & $\begin{array}{l}43 \\
.8 \\
8\end{array}$ & $\begin{array}{l}\text { Mixed } \\
\text { conifer/mixed } \\
\text { hardwood } \\
\text { forest }\end{array}$ & $\begin{array}{l}\text { Co } \\
\mathrm{mp} \\
\text { lia } \\
\text { nce }\end{array}$ & $\begin{array}{l}86 \\
, 8 \\
25\end{array}$ & $\begin{array}{c}35, \\
13 \\
7\end{array}$ & 2017 & IFM & $\begin{array}{c}\text { https://thereserve2.apx.com/mymodule/r } \\
\text { eg/TabProjectEmissions.asp?id1=1197\&a } \\
\text { d=Prpt\&act=update\&sBtn=\&r=111\&Type } \\
\text { =PRO\&tablename=cr\&aProj=pub }\end{array}$ & $\mathrm{NA}$ & $\begin{array}{l}\#(2017) ; \\
\%(2017) \\
2015, \\
2016,2017\end{array}$ & $\begin{array}{l}\text { \%\%PART VII. CARBON } \\
\text { STOCK INVENTORY } \\
\text { IFM-6 Soil (if applicable): } \\
\text { Excluded }\end{array}$ \\
\hline $\begin{array}{l}5 \\
3\end{array}$ & $\frac{\text { CAR1 }}{\underline{204}}$ & NA & $\begin{array}{l}\text { CA } \\
\text { FR5 } \\
304\end{array}$ & $\begin{array}{c}\text { AMC } \\
\text { Silver Lake } \\
\text { (Piscataqui } \\
\text { s \& } \\
\text { Aroostook } \\
\text { Counties, } \\
\text { ME) }\end{array}$ & $\begin{array}{c}- \\
69 . \\
15\end{array}$ & $\begin{array}{l}45 \\
.4 \\
4\end{array}$ & $\begin{array}{l}\text { Spruce-Fir and } \\
\text { Mixed } \\
\text { Hardwood } \\
\text { forests }\end{array}$ & $\begin{array}{l}\text { Co } \\
\mathrm{mp} \\
\text { lia } \\
\text { nce }\end{array}$ & $\begin{array}{l}89 \\
, 3 \\
15\end{array}$ & $\begin{array}{c}36, \\
14 \\
5\end{array}$ & 2017 & IFM & $\begin{array}{c}\frac{h \text { htps://thereserve2.apx.com/mymodule/r }}{\text { eg/TabProjectEmissions.asp?id1=1204\&a }} \\
\frac{\text { d=Prpt\&act=update\&sBtn=\&r=111\&Type }}{\text { EPRO\&tablename=cr\&aProj=pub }}\end{array}$ & $\mathrm{NA}$ & $\begin{array}{l}\#(2017) ; \\
\%(2017) \\
2015, \\
2016,2017\end{array}$ & $\begin{array}{l}\text { \%\%PART VII. CARBON } \\
\text { STOCK INVENTORY } \\
\text { IFM-6 Soil (if applicable): } \\
\text { Excluded }\end{array}$ \\
\hline $\begin{array}{l}5 \\
4\end{array}$ & $\frac{\text { CAR1 }}{\underline{209}}$ & NA & $\begin{array}{l}\text { CA } \\
\text { FR5 } \\
309\end{array}$ & $\begin{array}{l}\text { Wolf River } \\
\text { (Antigo, } \\
\text { WI) }\end{array}$ & $\begin{array}{c}- \\
88 . \\
86\end{array}$ & $\begin{array}{l}45 \\
.2 \\
3\end{array}$ & $\begin{array}{l}\text { Northern } \\
\text { hardwood/mixe } \\
\mathrm{d} \text { conifer } \\
\text { forestland }\end{array}$ & $\begin{array}{l}\text { Co } \\
\mathrm{mp} \\
\text { lia } \\
\text { nce }\end{array}$ & $\begin{array}{l}17 \\
, 7 \\
22\end{array}$ & $\begin{array}{l}7,1 \\
72\end{array}$ & 2017 & IFM & $\begin{array}{l}\frac{\text { https://thereserve2.apx.com/mymodule/r }}{\text { eg/TabProjectEmissions.asp?r }=111 \& a d=P} \\
\text { rpt\&act=update\&type=PRO\&aProj=pub\& } \\
\text { tablename=cr\&id1 }=1209\end{array}$ & $\mathrm{NA}$ & $\begin{array}{l}\#(2017) ; \\
\%(2017) \\
2015, \\
2016,2017\end{array}$ & $\begin{array}{l}\text { \%\%PART VII. CARBON } \\
\text { STOCK INVENTORY } \\
\text { IFM-6 Soil (if applicable): } \\
\text { Excluded }\end{array}$ \\
\hline $\begin{array}{l}5 \\
5\end{array}$ & $\frac{\text { CAR1 }}{\underline{213}}$ & NA & $\begin{array}{l}\text { CA } \\
\text { FR5 } \\
313\end{array}$ & $\begin{array}{c}\text { MWF } \\
\text { Adirondac } \\
\text { ks } \\
\text { (Franklin, } \\
\text { St. } \\
\text { Lawrence } \\
\text { \& Lewis } \\
\text { Counties, } \\
\text { NY) }\end{array}$ & $\begin{array}{c}- \\
74 . \\
91\end{array}$ & $\begin{array}{l}44 \\
.3 \\
5\end{array}$ & $\begin{array}{l}\text { Adirondacks \& } \\
\text { Green } \\
\text { Mountains } \\
\text { Northern } \\
\text { Hardwood }\end{array}$ & $\begin{array}{l}\text { Co } \\
\mathrm{mp} \\
\text { lia } \\
\text { nce }\end{array}$ & $\begin{array}{c}10 \\
0 \\
09 \\
4\end{array}$ & $\begin{array}{c}40 \\
50 \\
7\end{array}$ & 2017 & IFM & 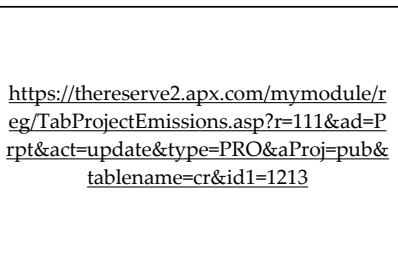 & $\mathrm{NA}$ & $\begin{array}{l}\#(2017) ; \\
\%(2017) \\
2015, \\
2016,2017\end{array}$ & $\begin{array}{l}\text { \%\%PART VII. CARBON } \\
\text { STOCK INVENTORY } \\
\text { IFM-6 Soil (if applicable): } \\
\text { Excluded" }\end{array}$ \\
\hline $\begin{array}{l}5 \\
6\end{array}$ & $\frac{\text { CAR1 }}{\underline{215}}$ & NA & $\begin{array}{l}\text { CA } \\
\text { FR5 } \\
315\end{array}$ & $\begin{array}{l}\text { Molpus } \\
\text { Ataya } \\
\text { (Campbell } \\
\text { \& }\end{array}$ & $\begin{array}{c}- \\
83 . \\
89\end{array}$ & $\begin{array}{l}36 \\
.5 \\
4\end{array}$ & $\begin{array}{l}\text { Allegheny \& } \\
\text { North } \\
\text { Cumberland } \\
\text { Mountains - }\end{array}$ & $\begin{array}{l}\text { Co } \\
\text { mp } \\
\text { lia }\end{array}$ & $\begin{array}{l}26 \\
, 2 \\
61\end{array}$ & $\begin{array}{c}10 \\
62 \\
7\end{array}$ & 2017 & IFM & $\begin{array}{l}\text { https://thereserve2.apx.com/mymodule/r } \\
\text { eg/TabProjectEmissions.asp?r=111\&ad=P } \\
\text { rpt\&act=update\&type=PRO\&aProj=pub\& }\end{array}$ & NA & $\begin{array}{l}\#(2017) ; \\
\%(2017) \\
2015,\end{array}$ & $\begin{array}{l}\text { \%\%PART VII. CARBON } \\
\text { STOCK INVENTORY } \\
\text { IFM-6 Soil (if applicable): }\end{array}$ \\
\hline
\end{tabular}




\begin{tabular}{|c|c|c|c|c|c|c|c|c|c|c|c|c|c|c|c|c|}
\hline & & & & $\begin{array}{l}\text { Claiborne } \\
\text { Counties, } \\
\text { TN) }\end{array}$ & & & $\begin{array}{l}\text { Mixed Pine } \\
\text { Hardwood, } \\
\text { Cove Forests, } \\
\text { Northern } \\
\text { Hardwoods, } \\
\text { Oak - Hickory }\end{array}$ & nce & & & & & tablename $=$ cr\&id1 $=1215$ & & 2016, 2017 & Excluded \\
\hline $\begin{array}{l}5 \\
7\end{array}$ & $\frac{\text { CAR1 }}{\underline{217}}$ & NA & $\begin{array}{l}\text { CA } \\
\text { FR5 } \\
317\end{array}$ & $\begin{array}{l}\text { West } \\
\text { Grand } \\
\text { Lake } \\
\text { (Washingt } \\
\text { on County, } \\
\text { ME) }\end{array}$ & $\begin{array}{c}- \\
67 . \\
75\end{array}$ & $\begin{array}{l}45 \\
.2 \\
3\end{array}$ & $\begin{array}{l}\text { New Brunswick } \\
\text { Foothills \& } \\
\text { Lowlands, } \\
\text { White } \\
\text { Mountains } \\
\text { Mixed } \\
\text { Hardwoods }\end{array}$ & $\begin{array}{l}\text { Co } \\
\text { mp } \\
\text { lia } \\
\text { nce }\end{array}$ & $\begin{array}{l}19 \\
, 5 \\
52\end{array}$ & $\begin{array}{l}7,9 \\
12\end{array}$ & 2015 & IFM & $\begin{array}{l}\underline{\text { https://thereserve2.apx.com/mymodule/r }} \\
\text { eg/TabProjectEmissions.asp?r=111\&ad=P } \\
\text { rpt\&act=update\&type=PRO\&aProj=pub\& } \\
\text { tablename }=\text { cr\&id1 } 1=1217\end{array}$ & NA & $\begin{array}{l}\#(2015) ; \\
\%(2015) \\
2013, \\
2014,2015\end{array}$ & $\begin{array}{l}\text { \%\%PART VII. CARBON } \\
\text { STOCK INVENTORY } \\
\text { IFM-6 Soil (if applicable): } \\
\text { Excluded" }\end{array}$ \\
\hline $\begin{array}{l}5 \\
8\end{array}$ & $\frac{\text { CAR9 }}{\underline{73}}$ & NA & $\begin{array}{l}\text { CA } \\
\text { FR5 } \\
003\end{array}$ & $\begin{array}{l}\text { Bishop } \\
\text { Project } \\
\text { (Near } \\
\text { Bessemer, } \\
\text { MI, and } \\
\text { other } \\
\text { locations) }\end{array}$ & $\begin{array}{c}- \\
87 . \\
85 \\
2\end{array}$ & $\begin{array}{c}46 \\
.5 \\
62 \\
0\end{array}$ & $\begin{array}{l}\text { Tree cover, } \\
\text { broadleaved, } \\
\text { deciduous, } \\
\text { closed to open } \\
(>15 \%)\end{array}$ & NA & $\begin{array}{l}2, \\
11 \\
2 . \\
86\end{array}$ & $\begin{array}{c}85 \\
5.0 \\
44 \\
86 \\
2\end{array}$ & $\begin{array}{l}2013- \\
2016\end{array}$ & IFM & $\begin{array}{c}\text { https://thereserve2.apx.com/mymodule/r } \\
\text { eg/TabProjectEmissions.asp?id1=973\&ad } \\
=\text { Prpt\&act=update\&sBtn=\&r=111\&Type= } \\
\text { PRO\&tablename=cr\&aProj=pub }\end{array}$ & $\begin{array}{l}\text { https://thereserve2.apx.co } \\
\text { m/myModule/rpt/myrpt. } \\
\text { asp?r=802\&md=Prpt\&id1 } \\
=\% 201004\end{array}$ & $\$ 2013$ & $\begin{array}{l}\text { \%\% Blue Source - Bishop } \\
\text { Improved Forest } \\
\text { Management Project } \\
\text { ARB Project Listing Form } \\
\text { Attachments } \\
\text { February 4, 2013, Part V.B, } \\
\text { Soil carbon excluded. }\end{array}$ \\
\hline $\begin{array}{l}5 \\
9\end{array}$ & $\frac{\underline{\text { CAR1 } 1}}{\underline{004}}$ & NA & NA & $\begin{array}{l}\text { Berry } \\
\text { Summit } \\
\text { (Near } \\
\text { Eureka, } \\
\text { CA }\end{array}$ & $\begin{array}{c}- \\
12 \\
3.7 \\
58\end{array}$ & $\begin{array}{l}40 \\
.9 \\
05\end{array}$ & $\begin{array}{l}\text { Tree cover, } \\
\text { needle leaved, } \\
\text { evergreen, } \\
\text { closed to open } \\
(>15 \%)\end{array}$ & NA & $\begin{array}{l}2, \\
11 \\
2 . \\
86\end{array}$ & & 2013 & IFM & $\begin{array}{l}\text { https://thereserve2.apx.com/mymodule/r } \\
\text { eg/TabProjectEmissions.asp?id11 1004\&a } \\
\text { d=Prpt\&act=update\&sBtn=\&r=111\&Type } \\
\text { =PRO\&tablename=cr\&aProj=pub }\end{array}$ & NA & $\$ 2013$ & $\begin{array}{l}\% \% \text { Project Description } \\
\text { Document, Table 5, IFM-6 } \\
\text { not included }\end{array}$ \\
\hline $\begin{array}{l}6 \\
0\end{array}$ & $\frac{\text { CAR1 }}{\underline{174}}$ & NA & $\begin{array}{l}\text { CA } \\
\text { FR5 } \\
224\end{array}$ & $\begin{array}{l}\text { Eddie } \\
\text { Ranch } \\
\text { (Mendocin } \\
\text { o County, } \\
\text { CA) }\end{array}$ & $\begin{array}{c}- \\
12 \\
3.1 \\
7\end{array}$ & $\begin{array}{l}39 \\
.4 \\
56\end{array}$ & $\begin{array}{l}\text { Tree cover, } \\
\text { needle leaved, } \\
\text { evergreen, } \\
\text { closed to open } \\
(>15 \%)\end{array}$ & NA & $\begin{array}{c}2 \\
28 \\
6\end{array}$ & & 2017 & IFM & $\begin{array}{l}\text { https://thereserve2.apx.com/mymodule/r } \\
\text { eg/TabProjectEmissions.asp?id111174\&a } \\
\text { d=Prpt\&act=update\&sBtn=\&r=111\&Type } \\
\text { =PRO\&tablename=cr\&aProj=pub }\end{array}$ & NA & $\begin{array}{l}\$ 2017, \\
\% 2017\end{array}$ & $\begin{array}{l}\% \% \text { Application for Listing, } \\
\text { Part VII-A, IFM-6, Soil } \\
\text { Carbon, not applicable }\end{array}$ \\
\hline $\begin{array}{l}6 \\
1\end{array}$ & $\frac{\text { CAR1 }}{\underline{190}}$ & NA & $\begin{array}{l}\text { CA } \\
\text { FR5 } \\
220\end{array}$ & $\begin{array}{l}\text { Greenwoo } \\
\text { d Creek } \\
\text { (Mendocin } \\
\text { o County, } \\
\text { CA) }\end{array}$ & $\begin{array}{c}- \\
12 \\
3.6 \\
31\end{array}$ & $\begin{array}{l}39 \\
.0 \\
73\end{array}$ & $\begin{array}{l}\text { Tree cover, } \\
\text { needle leaved, } \\
\text { evergreen, } \\
\text { closed to open } \\
(>15 \%)\end{array}$ & NA & $\begin{array}{c}8 \\
65 \\
9\end{array}$ & $\begin{array}{l}3,5 \\
94 . \\
17\end{array}$ & $\begin{array}{l}2015- \\
2017\end{array}$ & IFM & $\begin{array}{l}\text { https://thereserve2.apx.com/mymodule/r } \\
\text { eg/TabProjectEmissions.asp?id111190\&a } \\
\text { d=Prpt\&act=update\&sBtn=\&r=111\&Type } \\
\text { =PRO\&tablename=cr\&aProj=pub }\end{array}$ & NA & $\begin{array}{l}\$ 2015- \\
2016- \\
2017 ; \\
\% 2015 \\
2016,2017\end{array}$ & $\begin{array}{l}\text { \%\% Application for Listing, } \\
\text { Part II-C, IFM-6, Soil } \\
\text { Carbon, not applicable }\end{array}$ \\
\hline $\begin{array}{l}6 \\
2\end{array}$ & $\frac{\underline{\text { CAR1 } 1}}{\underline{262}}$ & NA & NA & $\begin{array}{l}\text { San Juan } \\
\text { Lachao } \\
\text { Pueblo } \\
\text { Nuevo, } \\
\text { Oaxaca, } \\
\text { Mexico }\end{array}$ & $\begin{array}{c}- \\
97 . \\
12 \\
5\end{array}$ & $\begin{array}{l}16 \\
.1 \\
58\end{array}$ & $\begin{array}{l}\text { Tree Cover, } \\
\text { broadleaved, } \\
\text { deciduous, } \\
\text { closed }\end{array}$ & NA & $\begin{array}{l}32 \\
.8 \\
40 \\
.3 \\
1\end{array}$ & $\begin{array}{c}13 \\
29 \\
0\end{array}$ & $\begin{array}{l}2014- \\
2016\end{array}$ & $\begin{array}{c}\text { Forest } \\
\text { ry }\end{array}$ & $\begin{array}{l}\text { https://thereserve2.apx.com/mymodule/r } \\
\text { eg/TabProjectEmissions.asp?id11=1262\&a } \\
\text { d=Prpt\&act=update\&sBtn=\&r=111\&Type } \\
\text { =PRO\&tablename=cr\&aProj=pub }\end{array}$ & NA & $\begin{array}{l}\$ 2014 \\
2015 \\
2016 \\
\% 2014 \\
2015\end{array}$ & $\begin{array}{l}\text { \%\% Carbono en el suelo: No } \\
\text { se incluye, REPORTE DE } \\
\text { PROYECTO } \\
\text { Captura de Carbono en San } \\
\text { Juan Lachao, Oaxaca } \\
\text { San Juan Lachao Pueblo } \\
\text { Nuevo, Oaxaca } \\
11 \text { de octubre de } 2017 \\
\text { CAR1262 }\end{array}$ \\
\hline $\begin{array}{l}6 \\
3\end{array}$ & $\frac{\frac{\text { CAR1 }}{\underline{306}}}{\underline{n}}$ & NA & NA & $\begin{array}{l}\text { Ejido San } \\
\text { Nicolás } \\
\text { Totolapan, } \\
\text { CDMX, } \\
\text { Mexico }\end{array}$ & $\begin{array}{c}- \\
99 . \\
25 \\
44\end{array}$ & $\begin{array}{c}19 \\
.2 \\
99 \\
4\end{array}$ & $\begin{array}{l}\text { Tree cover, } \\
\text { broadleaved, } \\
\text { deciduous, } \\
\text { closed to open } \\
(>15 \%)\end{array}$ & NA & $\begin{array}{c}5, \\
30 \\
2 . \\
83\end{array}$ & $\begin{array}{l}2,1 \\
45 . \\
98\end{array}$ & $\begin{array}{l}2017- \\
2018\end{array}$ & $\begin{array}{c}\text { Forest } \\
\text { ry }\end{array}$ & $\begin{array}{l}\text { https://thereserve2.apx.com/mymodule/r } \\
\text { eg/TabProjectEmissions.asp?id11=1306\&a } \\
\text { d=Prpt\&act=update\&sBtn=\&r=111\&Type } \\
\text { =PRO\&tablename=cr\&aProj=pub }\end{array}$ & NA & $\begin{array}{l}\$ 2017 \\
2018\end{array}$ & $\begin{array}{l}\% \% \\
\text { https://thereserve2.apx.com, } \\
\text { mymodule/reg/TabDocume } \\
\text { nts.asp?r=111\&ad=Prpt\&act } \\
\text { =update\&type=PRO\&aProj= } \\
\text { pub\&tablename=doc\&id1 }=1\end{array}$ \\
\hline
\end{tabular}




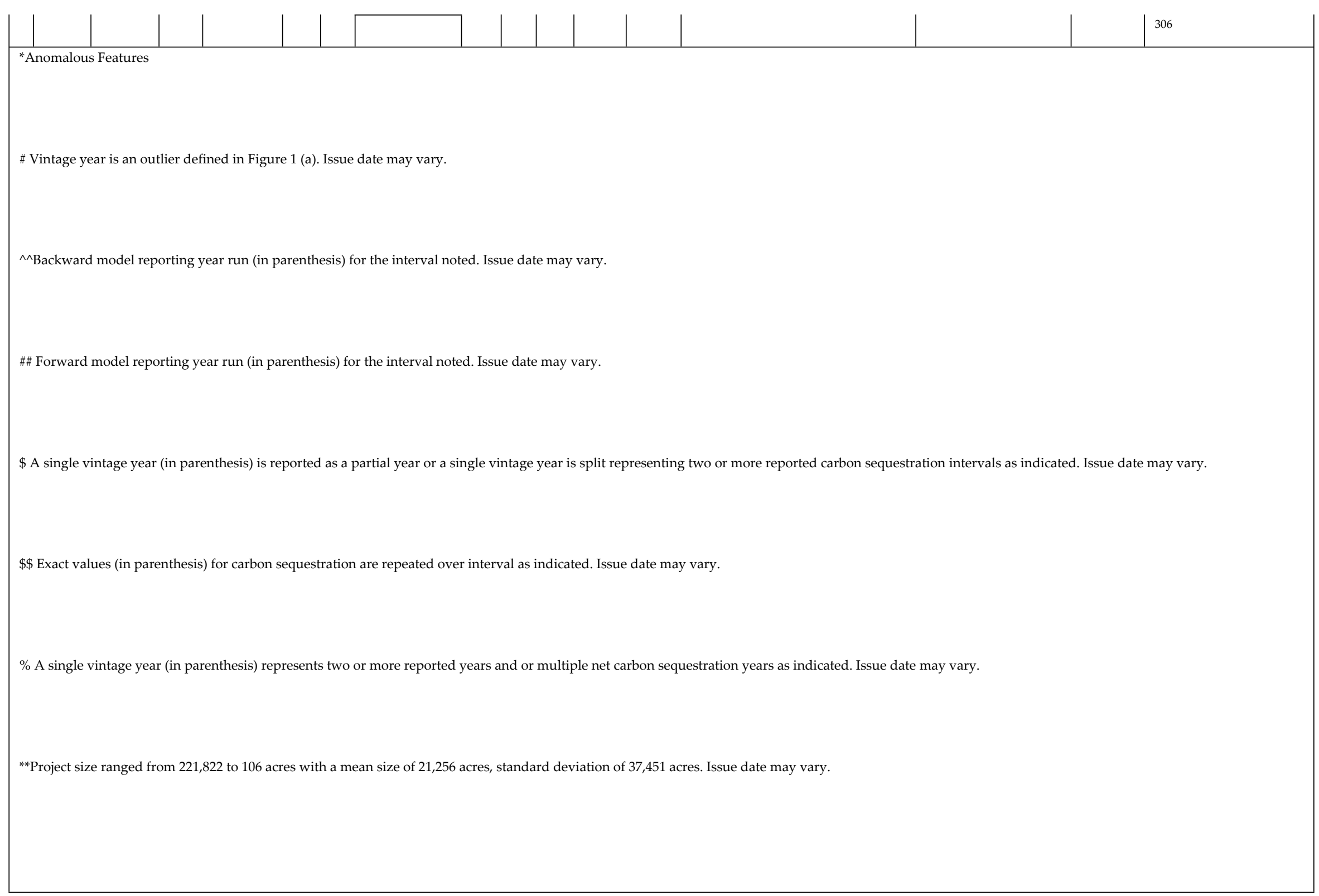


$\% \%$ Soil carbon pool excluded and not directly measured as specified in project documentation.

IFM: Improved Forest Management. This protocol applies to forest offset projects that involve management activities that maintain or increase carbon stocks on forested land relative to baseline levels of carbon stocks.

AC: Avoided Conversion. This protocol applies to forest offset projects that involve preventing the conversion of forestland to a non-forest land use by dedicating the land to continuous forest cover through a qualified conservation easement or transfer to public ownership, excluding transfer to federal ownership.

Footnote 1: For example, CAR 101 (Van Eck), CAR 102 (Garcia River), CAR 408 (Big River) and, CAR 429 (McCloud River) provide Project Activity (Tons), Confidence Deduction, Adjusted Project Activity and Baseline values for annual increments in the Cumulative Performance Reports page for each project (Table I). Values for "Project Activity (tons)", if interpreted as annual gross primary productivity, suggested by CARB-CAR equations (Supplement 2; "actual onsite carbon" as above ground carbon pools), yield a mean of 16,941.4 $\pm 4,694.2 \mathrm{gC} \mathrm{m}^{-2} \mathrm{yr}^{-1}$ ( $\mathrm{n}=39$ annual, CAR101,102,408,429) compared to GPP reported for NEE1 (n $=50$ sites, 487 annual values) of 1,269.8 $\pm 636^{65}$. The CARB-CAR values are in excess $\sim 13 x$ and $\sim 7 x$ of NEE1 mean and standard deviation, respectively, demonstrating the extreme and irreconcilable characteristics of the CARB-CAR methods. Initial-year data for the aforementioned sites (CAR101,102,408,429) were zero or small relative to the magnitude of project activity and baseline (e.g., CAR408, 1.4\%) (Table I). 


\section{Table 2 (on next page)}

Results of hypothesis test for all annual data

Results of a hypothesis test with a null hypothesis that the difference between the CARB-CAR and the NEE1 means is under the allowed $5 \%$ threshold. The test is performed separately for all years between 2002 and 2014, the p-values are recorded in the last two rows. 
2 Table II

3

\begin{tabular}{|c|c|c|c|c|c|c|c|c|c|c|c|c|c|c|}
\hline & 2002 & 2003 & 2004 & 2005 & 2006 & 2007 & 2008 & 2009 & 2010 & 2011 & 2012 & 2013 & 2014 & 2015 \\
\hline $\begin{array}{l}\text { CARB-CAR } \\
\text { mean }\end{array}$ & $\begin{array}{r}- \\
742.3 \\
1\end{array}$ & $\begin{array}{r}- \\
719.9 \\
4\end{array}$ & $\begin{array}{r}- \\
539.5 \\
1\end{array}$ & $\begin{array}{r}- \\
6921 .\end{array}$ & $\begin{array}{r}- \\
2038 . \\
03\end{array}$ & $\begin{array}{r}- \\
992.4 \\
2\end{array}$ & $\begin{array}{r}- \\
950.4 \\
7\end{array}$ & $\begin{array}{r}- \\
593.8 \\
6\end{array}$ & $\begin{array}{r}- \\
983.7 \\
4\end{array}$ & $\begin{array}{r}- \\
725.0 \\
4\end{array}$ & $\begin{array}{r}- \\
682.7 \\
7\end{array}$ & $\begin{array}{r}- \\
865.2 \\
7\end{array}$ & $\begin{array}{r}- \\
999.3 \\
8\end{array}$ & $\begin{array}{r}- \\
1432 . \\
69\end{array}$ \\
\hline $\begin{array}{l}\text { CARB-CAR } \\
\text { SD }\end{array}$ & $\begin{array}{r}928.7 \\
9\end{array}$ & $\begin{array}{r}585.9 \\
4\end{array}$ & $\begin{array}{r}1049 . \\
34\end{array}$ & $\begin{array}{r}683.2 \\
1\end{array}$ & $\begin{array}{r}3433 . \\
06\end{array}$ & $\begin{array}{r}1418 . \\
73\end{array}$ & $\begin{array}{r}1170 . \\
20\end{array}$ & $\begin{array}{r}644.8 \\
4\end{array}$ & $\begin{array}{r}1460 . \\
80\end{array}$ & $\begin{array}{r}1190 . \\
51\end{array}$ & $\begin{array}{r}1049 . \\
74\end{array}$ & $\begin{array}{r}1541 . \\
08\end{array}$ & $\begin{array}{r}1590 . \\
56\end{array}$ & $\begin{array}{r}1835 . \\
66\end{array}$ \\
\hline $\begin{array}{l}\text { CARB-CAR } \\
\text { (n) }\end{array}$ & 2.00 & 5.00 & 9.00 & 9.00 & 12.00 & 23.00 & 24.00 & 25.00 & 32.00 & 32.00 & 31.00 & 32.00 & 30.00 & 23.00 \\
\hline NEE1 mean & $\begin{array}{r}- \\
190.5 \\
5\end{array}$ & $\begin{array}{r}- \\
589.1 \\
5\end{array}$ & $\begin{array}{r}- \\
243.4 \\
5\end{array}$ & $\begin{array}{r}- \\
267.2 \\
6\end{array}$ & $\begin{array}{r}- \\
225.0 \\
8\end{array}$ & $\begin{array}{r}- \\
241.5 \\
1\end{array}$ & $\begin{array}{r}- \\
217.1 \\
6\end{array}$ & $\begin{array}{r}- \\
206.7 \\
5\end{array}$ & $\begin{array}{r}- \\
184.5 \\
1\end{array}$ & 92.29 & 93.45 & $\begin{array}{r}- \\
53.87\end{array}$ & -2.38 & -9.29 \\
\hline NEE1 SD & $\begin{array}{r}249.0 \\
6\end{array}$ & $\begin{array}{r}266.8 \\
0\end{array}$ & $\begin{array}{r}268.2 \\
5\end{array}$ & $\begin{array}{r}250.0 \\
2\end{array}$ & $\begin{array}{r}243.3 \\
9\end{array}$ & $\begin{array}{r}237.5 \\
6\end{array}$ & $\begin{array}{r}254.8 \\
6\end{array}$ & $\begin{array}{r}275.8 \\
9\end{array}$ & $\begin{array}{r}244.9 \\
3\end{array}$ & $\begin{array}{r}231.7 \\
1\end{array}$ & $\begin{array}{r}161.3 \\
9\end{array}$ & $\begin{array}{r}199.8 \\
5\end{array}$ & $\begin{array}{r}214.4 \\
6\end{array}$ & $\begin{array}{r}207.2 \\
5\end{array}$ \\
\hline $\operatorname{NEE1}(\mathrm{n})$ & 40.00 & 48.00 & 45.00 & 42.00 & 44.00 & 42.00 & 41.00 & 31.00 & 24.00 & 17.00 & 12.00 & 11.00 & 8.00 & 7.00 \\
\hline $\mathrm{p}$-value & 0.01 & 0.00 & 0.07 & 0.00 & 0.00 & 0.00 & 0.00 & 0.00 & 0.01 & 0.02 & 0.04 & 0.05 & 0.05 & 0.03 \\
\hline $\mathrm{p}$-value in $\%$ & 0.87 & 0.05 & 6.53 & 0.00 & 0.07 & 0.13 & 0.03 & 0.36 & 0.81 & 2.37 & 3.88 & 5.48 & 5.24 & 3.25 \\
\hline
\end{tabular}


Figure 1

Box plots of annual records from CARB-CAR (340 years, 63 sites) and NEE1 (540 years, 59 sites) projects.

Figure 1 (A). Figure 1 presents a box plot of annual records from CARB-CAR (340 years, 63 sites) and NEE1 (540 years, 59 sites) projects. The box plots show the median (white line through each box), the $25^{\text {th }}$ percentile (bottom of lower box), the $75^{\text {th }}$ percentile (top of upper box), the upper and lower whiskers represent the upper and lower values that are not outliers, and outliers (individual closed circles). The CARB-CAR data show outliers exceeding $-12,000 \mathrm{gC} \mathrm{m}^{-2} \mathrm{yr}^{-1}$. CARB-CAR median is $-445.1 \mathrm{gC} \mathrm{m}^{-2} \mathrm{yr}^{-1}$ compared to the NEE1 median value of $-172.5 \mathrm{gC} \mathrm{m}^{-2} \mathrm{yr}^{-1}$. The means and standard deviations $( \pm)$ are, $-948.8 \pm 1504.8$ and $-198.2 \pm 261.6$, for CARB-CAR and NEE1, respectively. (B) Box plots, described as above for CARB-CAR and NEE1 populations with CARB-CAR outliers removed.
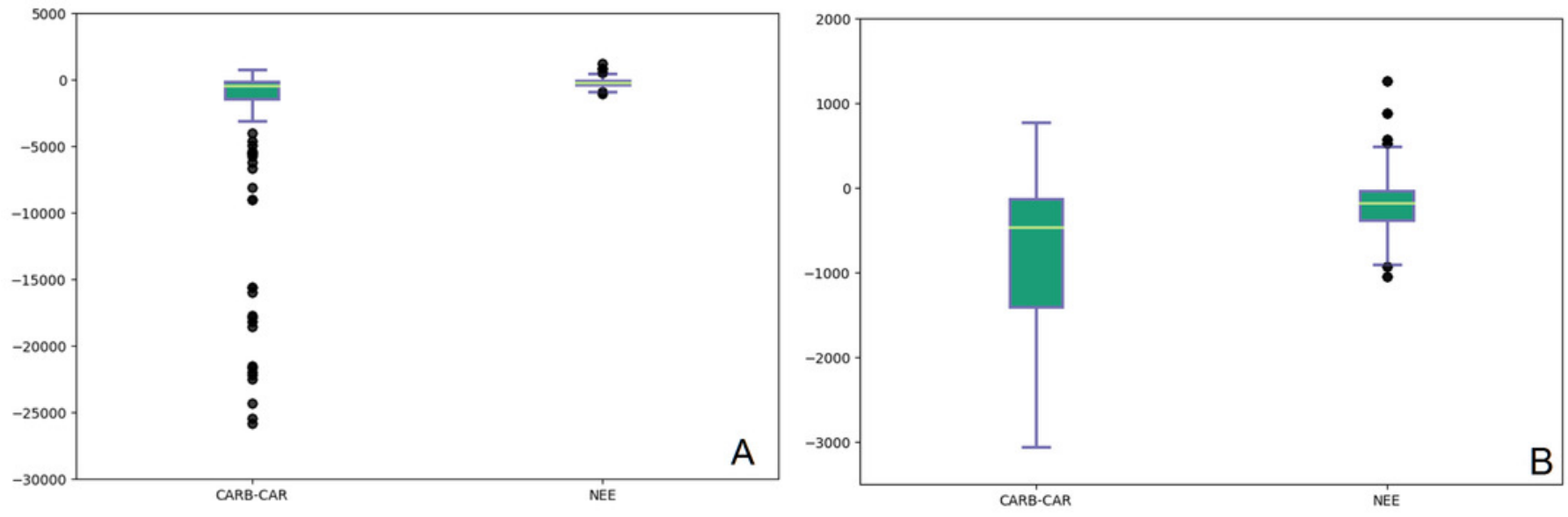


\section{Figure 2}

Plot of 95\% confidence interval for the difference in means between CARB-CAR and NEE1 annual data

Figure 2. Plot of the $95 \%$ confidence interval for the difference in means between the CARBCAR and NEE1 measurements. The combined data set (All Years) consists of 340 CARB-CAR and 540 NEE1 data points. A formula for a large-sample confidence interval (described in Methods) is used for the unfilled bars and no assumption on equal standard deviations between the two data sets has been made. ). The top and bottom of the open bars represent the range of the difference between the CARB-CAR and the NEE1 means with a 95\% confidence level. The filled square symbol below each bar represents the $5 \%$ estimation error allowed by CARB-CAR. 


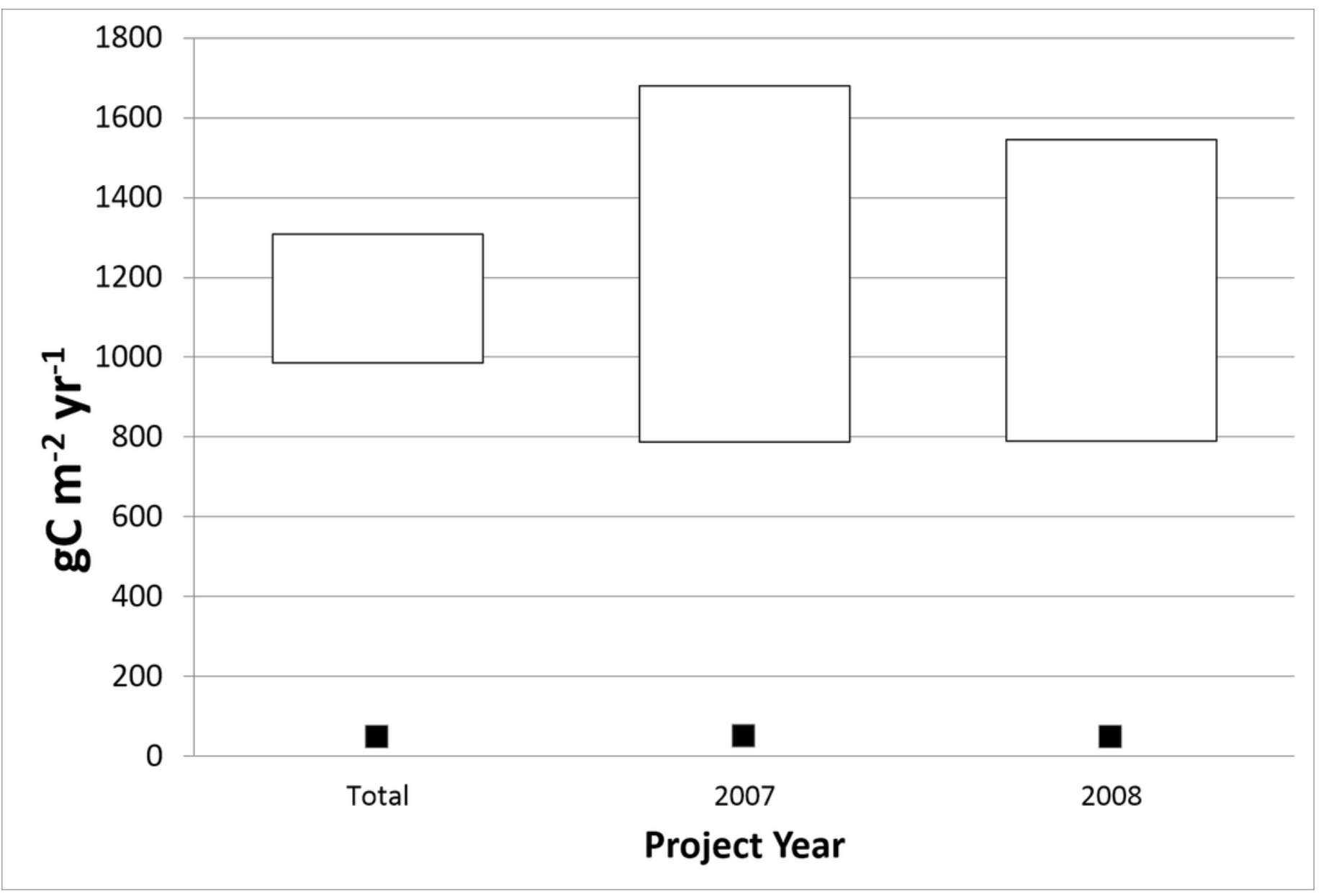


Figure 3

Time interval plot of CARB-CAR and NEE1 annual data.

Figure 3. Time interval plot of CARB-CAR data (open bars) from 2002 to 2015 and NEE1 measurements ${ }^{65}$ (filled bars) from 1992 to 2015 . Values are plotted as positive numbers representing net sequestration of carbon. The averages for the two data sets are shown by each bar representing forest carbon sequestration calculated annually over all available locations. The error bars represent $5 \%$ of the CARB-CAR year for 2006 and applied to all CARB-CAR project annual averages.

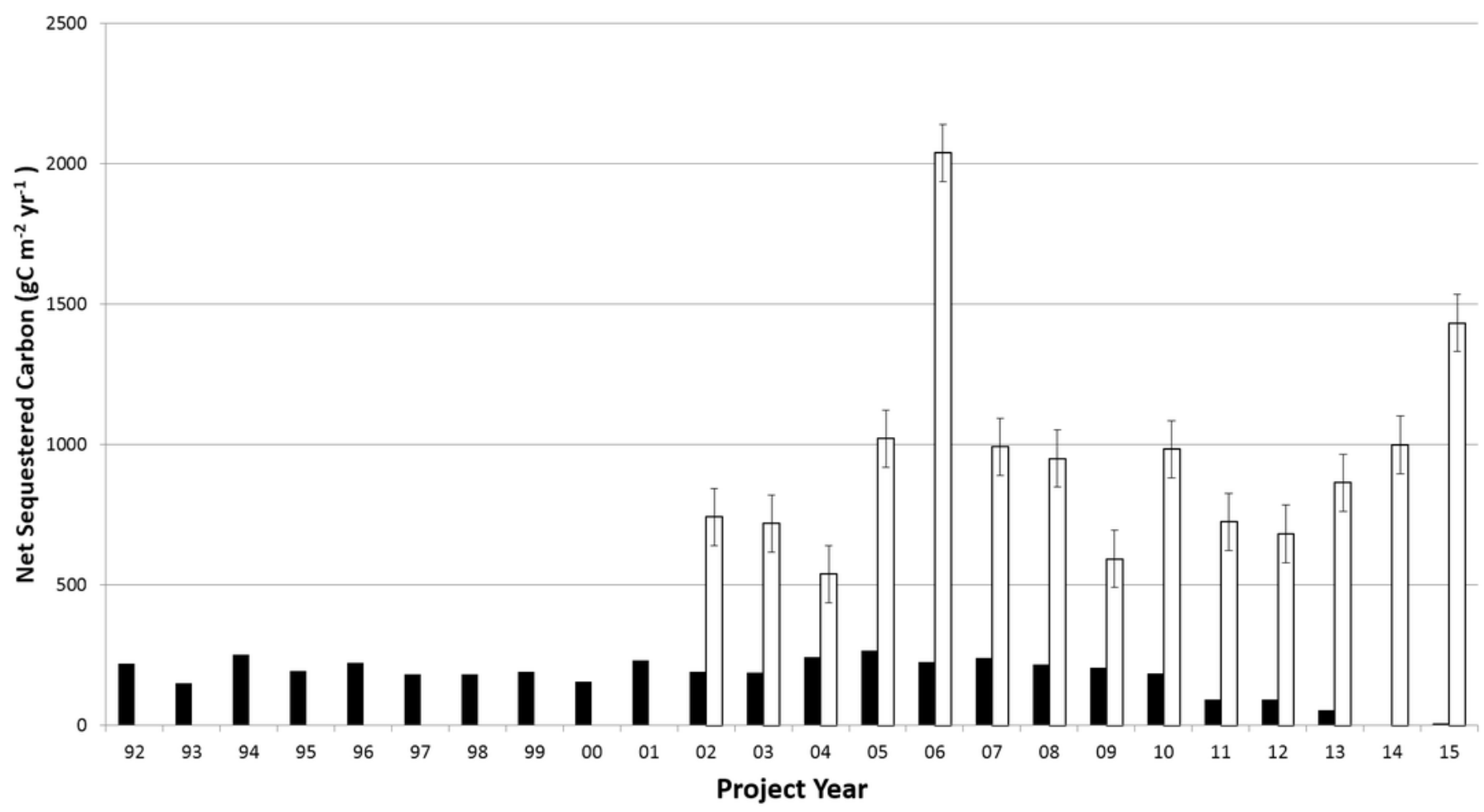

